\title{
Geohydrology and Evapotranspiration
}

at Franklin Lake Playa, Inyo County. California 


\section{AVAILABILITY OF BOOKS AND MAPS OF THE U.S. GEOLOGICAL SURVEY}

Instructions on ordering publications of the U.S. Geological Survey, along with prices of the last offerings, are given in the currentyear issues of the monthly catalog "New Publications of the U.S. Geological Survey." Prices of available U.S. Geological Survey publications released prior to the current year are listed in the most recent annual "Price and Availability List." Publications that may be listed in various U.S. Geological Survey catalogs (see back inside cover) but not listed in the most recent annual "Price and Availability List" may be no longer available.

Order U.S. Geological Survey publications by mail or over the counter from the offices given below.

\section{BY MAIL}

\section{Books}

Professional Papers, Bulletins, Water-Supply Papers, Techniques of Water-Resources Investigations, Circulars, publications of general interest (such as leaflets, pamphlets, booklets), single copies of Preliminary Determination of Epicenters, and some miscellaneous reports, including some of the foregoing series that have gone out of print at the Superintendent of Documents, are obtainable by mail from

\section{U.S. Geological Survey, Information Services Box 25286, Federal Center, Denver, CO 80225}

Subscriptions to Preliminary Determination of Epicenters can be obtained ONLY from the

\section{Superintendent of Documents \\ Government Printing Office \\ Washington, DC 20402}

(Check or money order must be payable to Superintendent of Documents.)

\section{Maps}

For maps, address mail orders to

U.S. Geological Survey, Information Services
Box 25286, Federal Center, Denver, CO 80225

\section{OVER THE COUNTER}

\section{Books and Maps}

Books and maps of the U.S. Geological Survey are available over the counter at the following U.S. Geological Survey Earth Science Information Centers (ESIC's), all of which are authorized agents of the Superintendent of Documents:

- ANCHORAGE, Alaska—Rm. 101, 4230 University Dr.

- LAKEWOOD, Colorado-Federal Center, Bldg. 810

- MENLO PARK, California-Bldg. 3, Rm. 3128, 345 Middlefield Rd.

- RESTON, Virginia-USGS National Center, Rm. 1C402, 12201 Sunrise Valley Dr.

- SALT LAKE CITY, Utah-Federal Bldg., Rm. 8105, 125 South State St.

- SPOKANE, Washington-U.S. Post Office Bldg., Rm. 135, West 904 Riverside Ave.

- WASHINGTON, D.C.-Main Interior Bldg., Rm. 2650, 18th and C Sts., NW.

\section{Maps Only}

Maps may be purchased over the counter at the following U.S. Geological Survey office:

- ROLLA, Missouri-1400 Independence Rd. 


\title{
Geohydrology and Evapotranspiration at Franklin Lake Playa, Inyo County, California
}

\author{
By JOHN B. CZARNECKI
}

With a section on ESTIMATING EVAPOTRANSPIRATION USING THE ENERGY-BUDGET EDDY-CORRELATION TECHNIQUE

BYDAVID I. STANNARD

Prepared in cooperation with NEVADA FIELD OFFICE

U.S. DEPARTMENT OF ENERGY 


\title{
U.S. DEPARTMENT OF THE INTERIOR BRUCE BABBITT, Secretary
}

\author{
U.S. GEOLOGICAL SURVEY
}

Gordon P. Eaton, Director

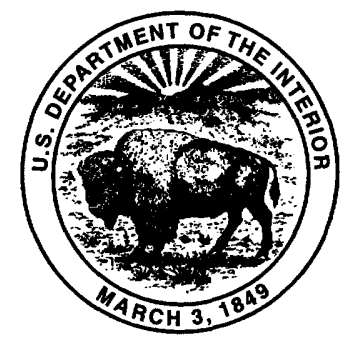

Any use of trade, product, or firm names in this publication is for descriptive purposes only and does not imply endorsement by the U.S. Government.

For sale by

U.S. Geological Survey, Information Services

Box 25286, Federal Center

Denver, CO 80225

\section{Library of Congress Cataloging-in-Publication Data}

Czarnecki, John B.

Geohydrology and evapotranspiration at Franklin Lake playa, Inyo County, California/ by John B. Czarnecki.

p. $\quad$ cm. - (U.S. Geology Survey water-supply paper ; 2377)

"With a section on estimating evapotranspiration using the energy-budget eddycorrelation technique by David I. Stannard."

"Prepared in cooperation with the U.S. Department of Energy."

Includes bibliographical references.

Supt. of Docs. no.: I 19.13:

1. Hydrogeology-California-Franklin Lake Watershed. 2. Evapotranspiration-California-Franklin Lake Watershed. I. Stannard, David I. II. United States. Depart. of Energy. III. Title. IV. Series. 


\section{CONTENTS}

Abstract

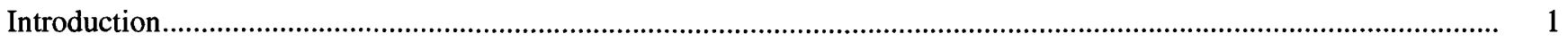

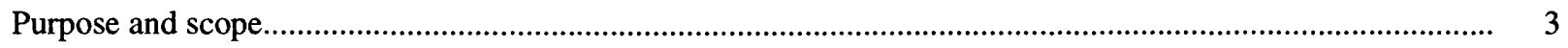

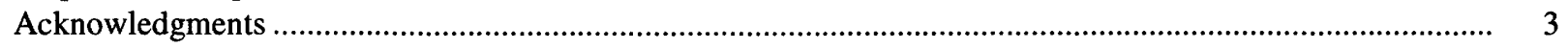

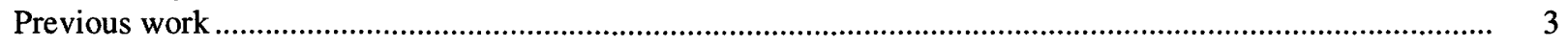

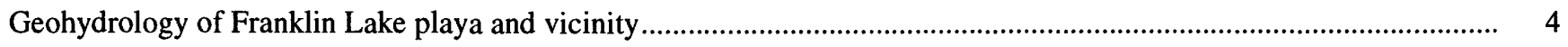

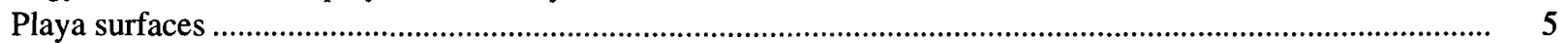

Hard, compact surface .............................................................................................................. 5

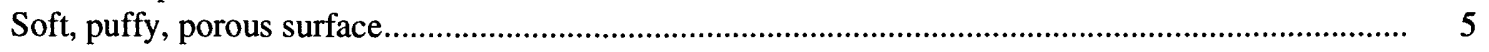

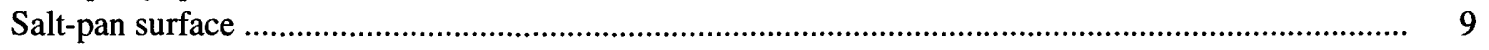

Stream-channel surface ........................................................................................................ 9

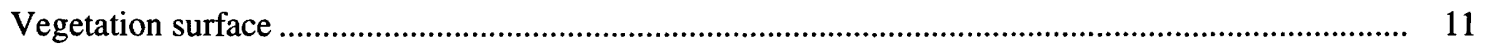

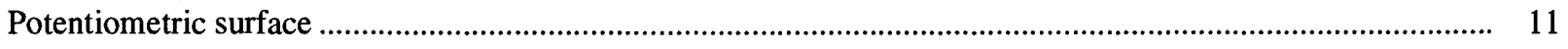

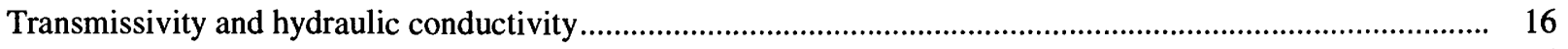

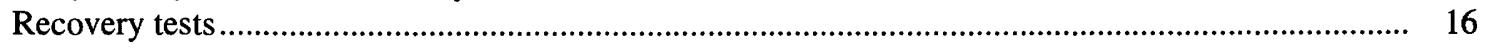

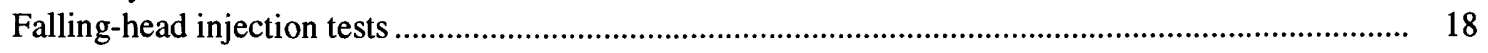

Falling-head permeameter tests .................................................................................................... 19

Estimation of effective pneumatic diffusivity and intrinsic permeability of the unsaturated zone ........ 21 Air-temperature effect ......................................................................................... 23

The Klinkenberg effect .................................................................................... 23

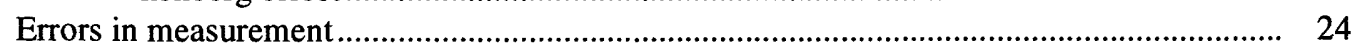

Summary of transmissivity and hydraulic-conductivity estimates .................................................... 24

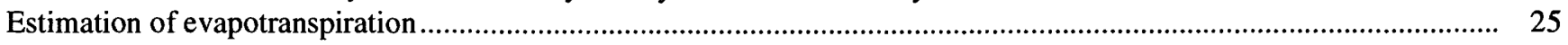

Energy-balance eddy-correlation technique, by David I. Stannard ................................................................. 25

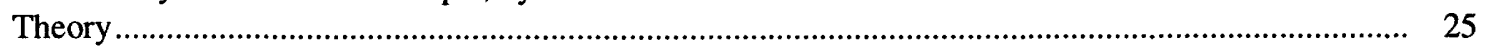

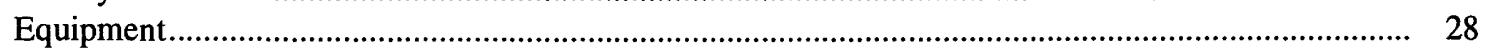

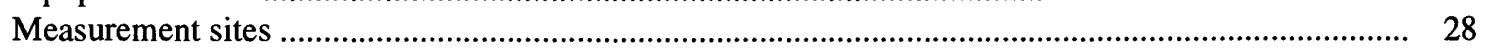

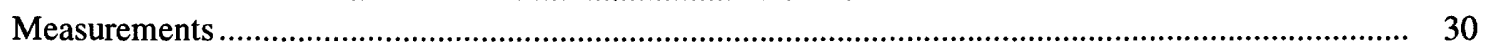

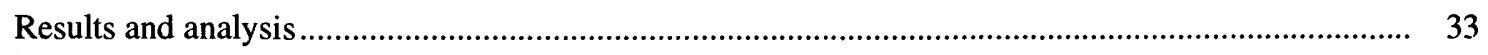

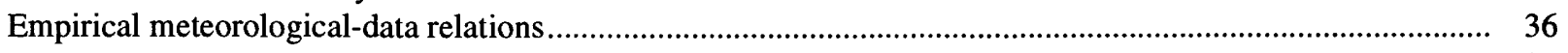

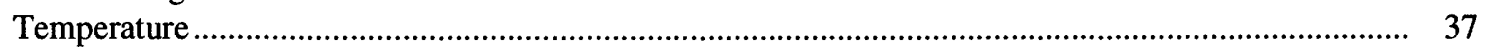

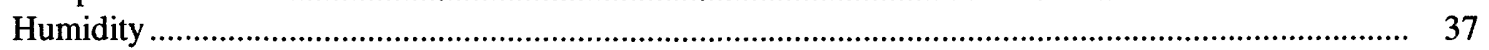

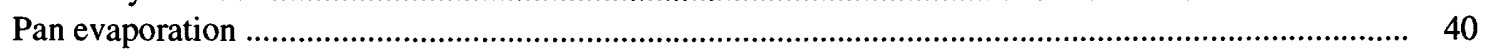

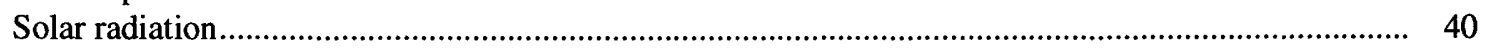

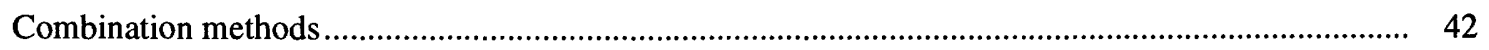

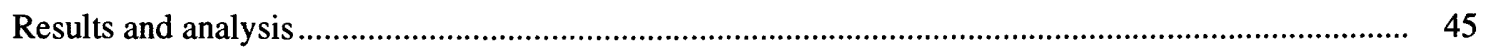

Moisture content in the unsaturated zone ........................................................................................ 47

Evapotranspiration by phreatophytes .................................................................................................... 49

Vertical ground-water velocity estimated from temperature logs ......................................................... 49

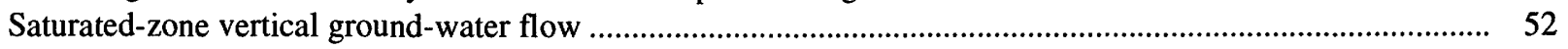

One-dimensional model of variably saturated ground-water flow ..................................................... 52

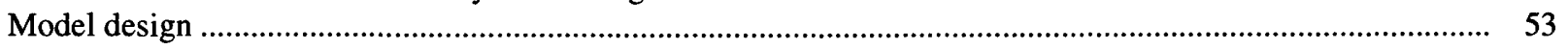

Model variables and sensitivity analyses............................................................................... 53

Moisture-characteristic-curve variables ..................................................................... 54

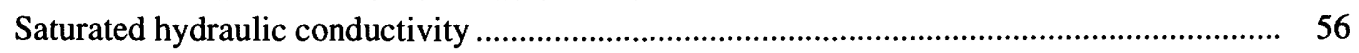

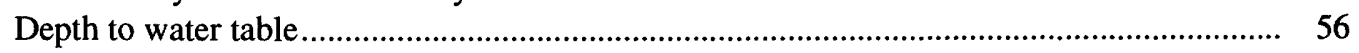

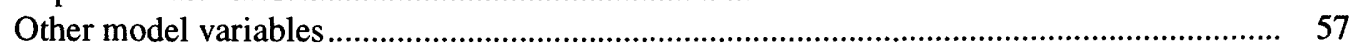

Model-calculated evaporative flux results.......................................................................... 57

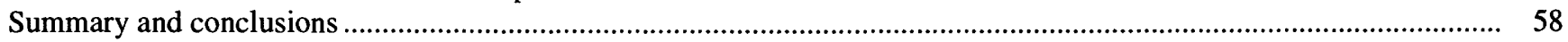

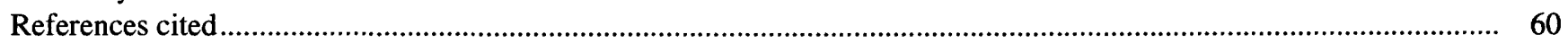




\section{FIGURES}

1. Map showing location of the Franklin Lake playa study area near the California-Nevada border.....

2. Block diagram showing generalized structure and lithology in the Franklin Lake playa study area

3. Map showing distribution of Franklin Lake playa surfaces

4. Map showing study sites at Franklin Lake playa

5. Photographs showing mud cracks on stream-channel surface and mud cracks and soft, puffy, porous surface ...

6-8. Photographs showing:

6. Salt pan crust at Ojo del Caballo site and surface at East study site

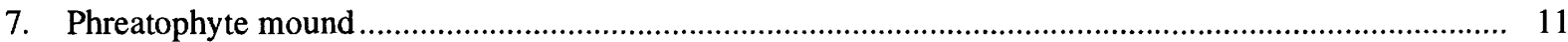

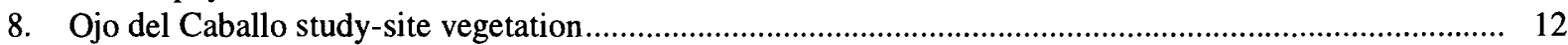

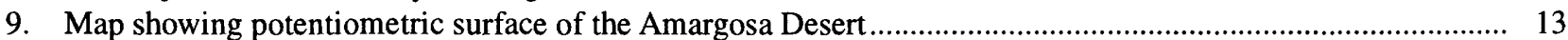

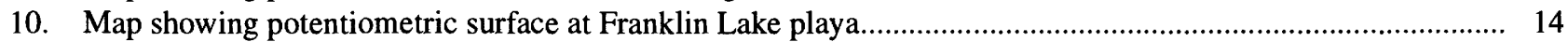

11. Diagram showing typical piezometer nest construction......................................................................... 16

12. Map showing difference in altitude between potentiometric surface and land surface at Franklin Lake playa.... 17

13. Water levels recorded at wells and barometric pressures recorded at Yucca Mountain from February 4 to March 6, 1985

14. Graph showing recovery tests for wells 5 and 14 at Franklin Lake playa.

15. General schematic diagram showing view of a falling-head permeameter and detailed view of a falling-head permeameter.

16. Graph showing relation of root-mean-squared error to various trial values of effective pneumatic diffusivity ... 23

17. Graph showing predicted and measured changes in water levels in well 5 resulting from changes in atmospheric pressure at Franklin Lake playa

18. Diagram showing the energy-balance method for estimating evapotranspiration........................................... 27

19-21. Photographs showing:

19. Net radiometer and soil-heat-flux plate

20. Sonic anemometer

21. Solid-state datalogger

22. Map showing location of eddy-correlation sites

23. Photograph showing the North site during energy-balance eddy-correlation measurements of evapotranspiration

24. Photograph of South-Central site showing puffy, porous surface

25. Graphs showing a typical 24-hour time series of net-radiation and soil-heat flux, sensible-heat flux, and latent-heat flux

26. Graphs showing evapotranspiration rates for the North and South-Central sites, for all sites, and for a comparison of the average for the North and South-Central sites with the average for all sites...

27. Photograph showing Eagle Mountain with dust blowing over the top as viewed from Franklin Lake playa .

28. Graph showing summary of potential evapotranspiration estimation results

29. Graph showing evapotranspiration estimates based on energy-budget eddy-correlation technique and selected equations

30. Histogram showing distribution of fluxes estimated from change in soil-moisture contents with time.

31. Diagram showing idealized temperature profiles for upward, downward, and no vertical ground-water flow within the saturated zone below the zone of surface heating and cooling effects

32. Graphs showing temperature profiles for selected wells at Franklin Lake playa

33. Diagram showing model grid design and boundary conditions

34-41. Graphs showing:

34. Relation between soil-moisture saturation and soil-moisture tension for data collected at various locations at Franklin Lake playa

35. Relation between the natural logarithm of effective-saturation data and the natural logarithm of soil-moisture tension 
36. Sensitivity analysis of the effect of varying model value of the bubbling-pressure head, $h_{\mathrm{b}} \ldots \ldots \ldots \ldots \ldots \ldots \ldots . . . \ldots \ldots$

37. Sensitivity analysis of the effect of varying model value of the pore-size distribution exponent, $\lambda \ldots \ldots \ldots \ldots . . .55$

38. Sensitivity analysis of the effect of varying model value of saturated hydraulic conductivity................... 56

39. Sensitivity analysis of the effect of varying model value of depth to the water table ............................. 56

40. Changes in model-calculated evaporation rate through time............................................................... 57

41. Model results of saturation profile and total negative pressure head ................................................. 57

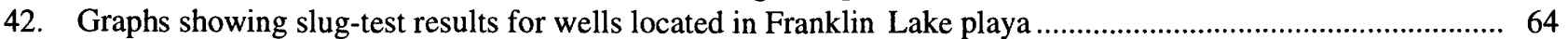

43-49. Graphs showing sensitivity analysis of the effect of varying model value of:

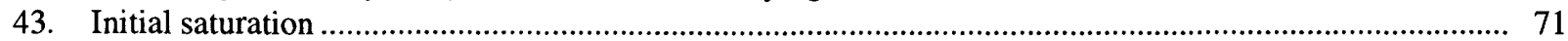

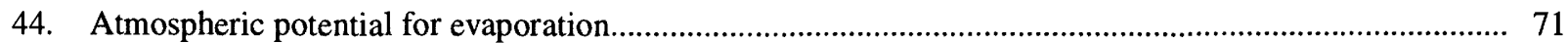

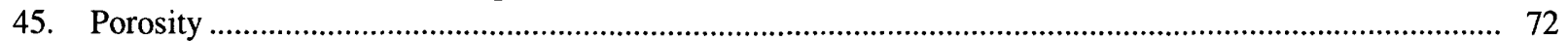

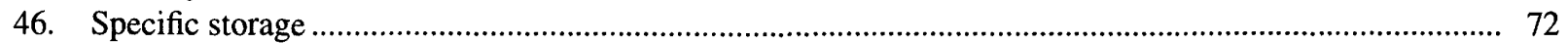

47. Specified upward-head pressure at the lower boundary ....................................................................... 72

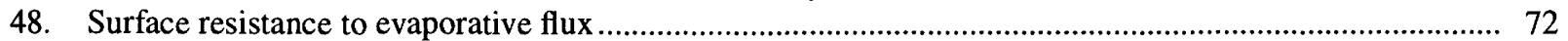

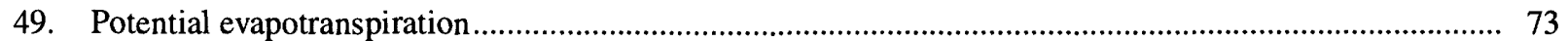

\section{TABLES}

1. Summary of water-level data for piezometers at Franklin Lake playa, May 1983 through March 1985 ............. 15

2. Summary of slug-test results for several wells at Franklin Lake playa........................................................... 20

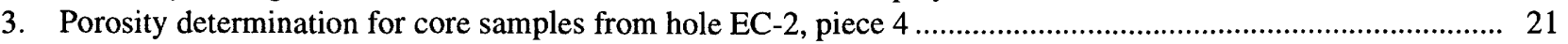

4. Summary of transmissivity and hydraulic-conductivity values obtained from all techniques ............................ 25

5. Measurement periods used for the energy-budget eddy-correlation technique ................................................ 32

6. Average daily evapotranspiration rates estimated using the energy-budget eddy-correlation technique .............. 35

7-17. Estimated potential evapotranspiration at Franklin Lake playa using the technique of:

7. Ivanov (1954) and Turc (1961) for meteorologic data for Mercury, Nevada .............................................. 38

8. Papadakis (1966) for meteorologic data for Mercury, Nevada ................................................................ 38

9. Papadakis (1966) for meteorologic data for Boulder City, Nevada, during 1982 ................................... 39

10. Papadakis (1966) for meteorologic data for Boulder City, Nevada, during 1983.................................... 39

11. Doorenbos and Pruitt (1974) for pan evaporation data for Boulder City, Nevada, 1982 through 1983 ....... 40

12. Jensen and Haise (1963) and Stephens (1965) for meteorological data .................................................. 41

13. Benke and Maxey (1969) for meteorological data.................................................................................... 42

14. Linacre (1969) for temperature data for Mercury, Nevada ............................................................... 43

15. Linacre (1969) for temperature data for Boulder City, Nevada, for 1982 .............................................. 43

16. Linacre (1969) for temperature data for Boulder City, Nevada, for 1983 ............................................... 44

17. Linacre (1969) for temperature data for Silverpeak, Nevada, for 1983 .................................................. 44

18. Estimated potential evapotranspiration at Franklin Lake playa using the nomograph for shallow lake evaporation presented in Linsley and others $(1975$, p. 161)...

19. Measured and predicted evapotranspiration at Franklin Lake playa using average monthly temperature and

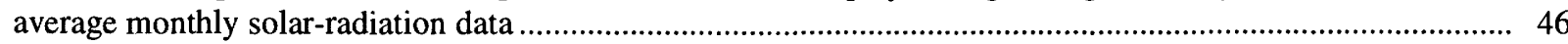

20. Summary of variable values for the one-dimensional column simulation using variably saturated, two-dimensional finite-difference model ........................................................................................................ 54

21. Moisture-characteristic-curve parameters at different values of residual-moisture content ................................ 55

22. Summary of evapotranspiration estimates from all techniques used ............................................................. 59

23. Falling-head permeameter results for sample 3 from core taken from core hole EC-2, Franklin Lake playa ....... 69

24. Falling-head permeameter results for sample 4 from core taken from core hole EC-2, Franklin Lake playa ...... 70

25. Falling-head permeameter results for sample 3 from core taken from piece 7 from core hole EC-3,

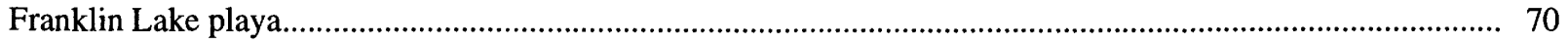

26. Falling-head permeameter results for sample 4 from core taken from piece 7 from core hole EC-3, Franklin Lake playa 


\begin{tabular}{|c|c|c|}
\hline Multiply & By & To obtain \\
\hline cemtimeter $(\mathrm{cm})$ & 0.3937 & inch \\
\hline centimeter per annum (cm/a) & 0.3937 & inch per year \\
\hline centimeter per day $(\mathrm{cm} / \mathrm{d})$ & 0.3937 & inch per day \\
\hline centimeter per second $(\mathrm{cm} / \mathrm{s})$ & 0.3937 & inch per second \\
\hline cubic meter per day $(\mathrm{m} 3 / \mathrm{d})$ & 264.2 & gallon per day \\
\hline $\begin{array}{l}\text { dynes per cubic centimeter } \\
\qquad\left(\mathrm{dynes} / \mathrm{cm}^{3}\right)\end{array}$ & $1.45 \times 10^{-5}$ & pounds per square inch \\
\hline $\begin{array}{l}\text { gram per cubic centimeter } \\
\qquad\left(\mathrm{g} / \mathrm{cm}^{3}\right)\end{array}$ & 62.43 & pounds per cubic foot \\
\hline gram per cubic centimeter & $6.243 \times 10^{-5}$ & pounds per cubic foot \\
\hline gram per cubic meter & $6.243 \times 10^{-5}$ & pounds per cubic foot \\
\hline $\begin{array}{l}\text { gram per second per } \\
\text { square meter }\end{array}$ & 0.1966 & $\begin{array}{l}\text { ounce per minute per } \\
\text { square foot }\end{array}$ \\
\hline hertz $(\mathrm{Hz})$ & 1 & cycles per second \\
\hline 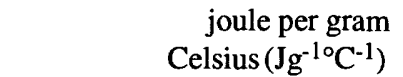 & 334.6 & $\begin{array}{l}\text { foot-pounds per pound } \\
\text { degree Fahrenheit }\end{array}$ \\
\hline joule per kilogram $(\mathrm{J} / \mathrm{kg})$ & 0.3346 & foot-pounds per pound \\
\hline joule per cubic meter $\left(\mathrm{J} / \mathrm{m}^{3}\right)$ & 0.0209 & foot-pounds per cubic foot \\
\hline kilometer $(\mathrm{km})$ & 0.6214 & mile \\
\hline kilometer per day & 0.6214 & mile per day \\
\hline langley per day & 3.687 & $\begin{array}{l}\text { British thermal unit per } \\
(\text { second } \times \text { square foot) }\end{array}$ \\
\hline liter per minute $(\mathrm{L} / \mathrm{min})$ & 0.2642 & gallon per minute \\
\hline liter per second $(\mathrm{L} / \mathrm{s})$ & 15.85 & gallon per minute \\
\hline meter $(\mathrm{m})$ & 3.281 & foot \\
\hline $\begin{array}{r}\text { meter degree Celsius per } \\
\text { second }\left(\mathrm{m}^{\circ} \mathrm{Cs}^{-1}\right)\end{array}$ & 354.3 & $\begin{array}{l}\text { foot degree Fahrenheit } \\
\text { per minute }\end{array}$ \\
\hline meter per annum (m/a) & 3.281 & foot per year \\
\hline meter per day $(\mathrm{m} / \mathrm{d})$ & 3.281 & foot per day \\
\hline meter squared per day $\left(\mathrm{m}^{2} / \mathrm{d}\right.$ & 10.76 & foot squared per day \\
\hline meter squared per hour $\left(\mathrm{m}^{2} / \mathrm{h}\right)$ & 10.76 & foot squared per hour \\
\hline micrometer $(\mu \mathrm{m}$ & 0.00003937 & inch \\
\hline $\begin{array}{l}\text { microvolt square meter } \\
\text { per watt }\left(\mu \mathrm{Vm}^{2} \mathrm{~W}^{-1}\right)\end{array}$ & 0.2432 & $\begin{array}{l}\text { microvolt square foot minute } \\
\text { per foot-pound }\end{array}$ \\
\hline millibar & 0.02953 & inch of mercury $\left(32^{\circ} \mathrm{F}\right)$ \\
\hline millimeter $(\mathrm{mm})$ & 0.03937 & inch \\
\hline millimeter per day $(\mathrm{mm} / \mathrm{d})$ & 0.03937 & inch per day \\
\hline millimeter per month & 0.03937 & inch per month \\
\hline millimeter per annum (mm/a) & 0.03937 & inch per year \\
\hline square kilometer $\left(\mathrm{km}^{2}\right)$ & 0.3861 & square mile \\
\hline watt per square meter $\left(\mathrm{Wm}^{-2}\right)$ & 4.111 & $\begin{array}{l}\text { foot-pounds per square foot } \\
\text { per minute }\end{array}$ \\
\hline 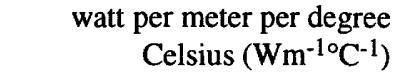 & 7.494 & $\begin{array}{l}\text { Foot-pounds per minute per } \\
\text { foot per degree Fahrenheit }\end{array}$ \\
\hline inch (in.) & 2.54 & centimeter \\
\hline feet $(\mathrm{ft})$ & 3.281 & meter \\
\hline
\end{tabular}

Temperature can be converted to degree Celsius $\left({ }^{\circ} \mathrm{C}\right)$ or degree Fahrenheit $\left({ }^{\circ} \mathrm{F}\right)$ by the equations:

${ }^{\circ} \mathrm{C}=5 / 9\left({ }^{\circ} \mathrm{F}-32\right)$

${ }^{\circ} \mathrm{F}=9 / 5\left({ }^{\circ} \mathrm{C}\right)+32$.

Sea level: In this report "sea level" refers to the National Geodetic Vertical Datum of 1929 (NGVD of 1929)—a geodetic datum derived from a general adjustment of the first-order level nets of both the United States and Canada, formerly called Sea Level Datum of 1929. 


\title{
Geohydrology and Evapotranspiration at Franklin Lake Playa, Inyo County,California
}

\author{
By John B. Czarnecki
}

\section{Abstract}

Franklin Lake playa is one of the principal discharge areas of the Furnace Creek Ranch-Alkali Flat ground-water-flow system in southern Nevada and adjacent California. Yucca Mountain, Nevada, located within this flow system, is being evaluated by the U.S. Department of Energy to determine its suitability as a potential site for a high-level nuclear-waste repository. To assist the U.S. Department of Energy with its evaluation of the Yucca Mountain site, the U.S. Geological Survey developed a parameter-estimation model of the Furnace Creek Ranch-Alkali Flat ground-water-flow system. Results from sensitivity analyses made using the parameter-estimation model indicated that simulated rates of evapotranspiration at Franklin Lake playa had the largest effect on the calculation of transmissivity values at Yucca Mountain of all the model-boundary conditions and, therefore, that evapotranspiration required careful definition.

Measurements to estimate evapotranspiration were made between June 1983 and April 1984 by using the eddy-correlation technique. Evapotranspiration estimated as a residual of the energy-balance equation ranged from about $0.1 \mathrm{~cm} / \mathrm{d}$ (centimeter per day) during winter months to about $0.3 \mathrm{~cm} / \mathrm{d}$ during summer months. Energy-balance estimates were compared with evapotranspiration estimates made using: (1) empirical relations of meteorological data to estimate potential evapotranspiration (range, 0.1 to 1.7 $\mathrm{cm} / \mathrm{d}$ ); (2) temporal variations in soil-moisture content in the unsaturated zone (range, -0.07 to $0.1 \mathrm{~cm} / \mathrm{d}$ ); (3) estimates of evapotranspiration by phreatophytes in the Owens and Santa Ana Valleys (range, 0.09 to 0.34 $\mathrm{cm} / \mathrm{d}$ ); (4) temperature profiles for the saturated zone (range, inconclusive); (5) saturated-zone vertical gradients (range, 0.06 to $0.5 \mathrm{~cm} / \mathrm{d}$ ); and (6) a one-dimensional finite-difference model of vertical ground-water flow from the water table to land surface (steady-state estimate, $0.06 \mathrm{~cm} / \mathrm{d}$ ). Sensitivity analyses made with this model indicated that evaporation estimates are most sensitive to variations in the specified values of variables of the Brooks-Corey moisture-characteristic curve (bubbling pressure and the pore-size distribution exponent, $\lambda$ ) and to variations in saturated hydraulic conductivity. Of all the techniques used, the results from the energy-balance eddy-correlation technique are considered to be the most reliable because they were the most direct.

\section{INTRODUCTION}

In arid-climate, regional ground-water-flow systems, discharge that results from evapotranspiration is a major component of ground-water flux. Accurate determination of the rate of evapotranspiration is needed to estimate ground-water-flow rates and directions within these systems because evapotranspiration can be a major boundary condition when numerical models of ground-water flow are applied. Further, evapotranspiration generally can be measured more easily than its counterpart, recharge, and, for this reason, is typically specified explicitly and exerts a substantial influence in the mass balance of these models.

Yucca Mountain (fig. 1), located on the western edge of the Nevada Test Site, is being studied by the U.S. Department of Energy as a potential site for a mined geologic repository for storing high-level radioactive waste. As part of these studies, the U.S.

Geological Survey is investigating the ground-water-flow system beneath Yucca Mountain and vicinity because of the potential for ground water 


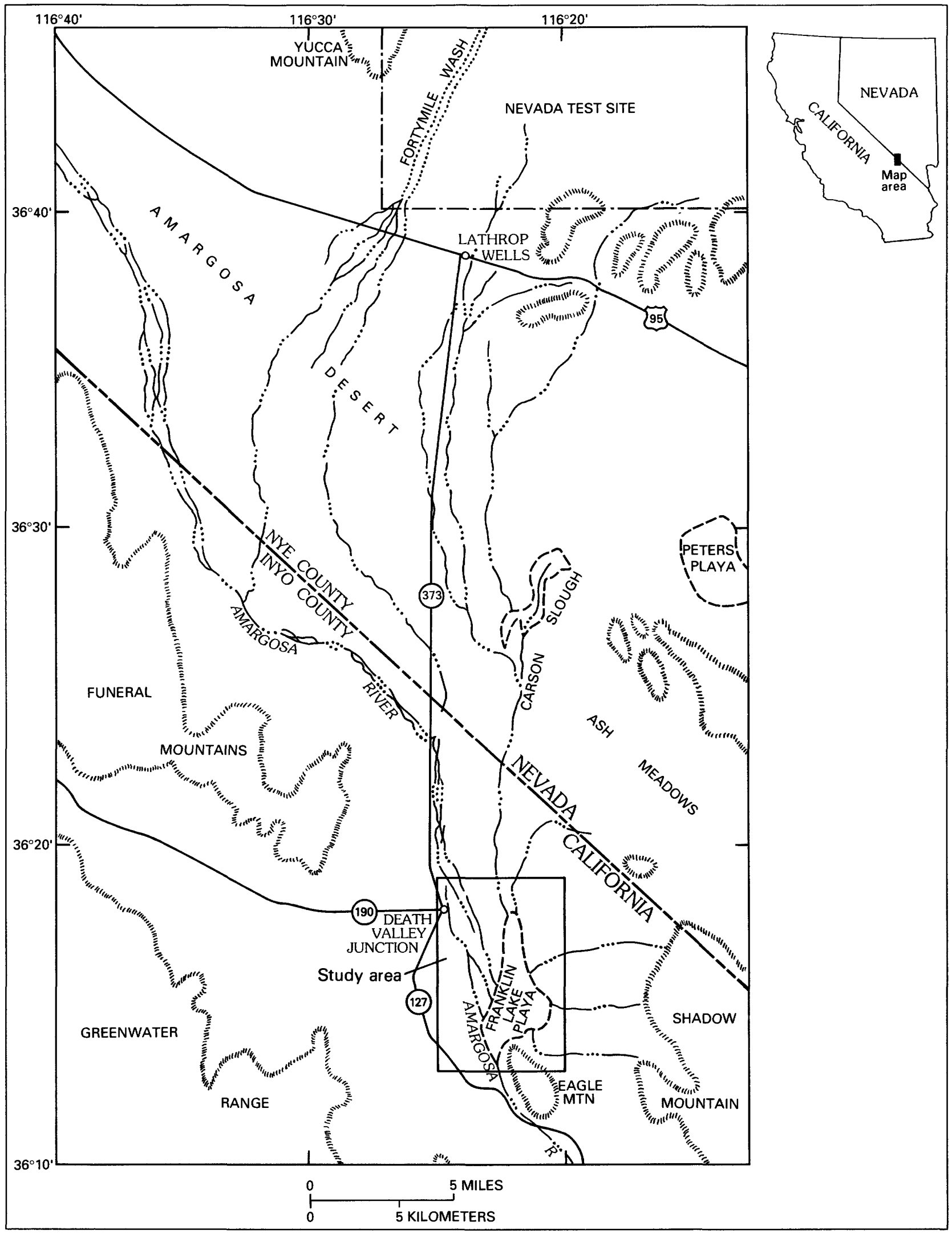

Figure 1. Location of the Franklin Lake playa study area near the California-Nevada border. 
to transport radionuclides away from a repository to the accessible environment. These investigations, done in cooperation with the U.S. Department of Energy under Interagency Agreement DE-AI08-78ET44802, are part of the Yucca Mountain Project, formerly the Nevada Nuclear Waste Storage Investigations.

The ground-water-flow system beneath Yucca Mountain and vicinity was studied and modeled (Czarnecki and Waddell, 1984) using a parameter-estimation method to provide an understanding of the ground-water-flow system and an understanding of the sensitivity of the model to changes in model-flux variables. From the sensitivity analyses performed, the ground-water discharge that occurs as evapotranspiration at Franklin Lake playa, which is one of the principal ground-water-discharge areas, was determined to have the largest effect on the calculation of transmissivity values at, and downgradient from, Yucca Mountain. Because little was known about the rate of ground-water discharge and evapotranspiration, onsite investigations were done at Franklin Lake playa to quantify these rates and to determine the position of the water table and values of other hydrologic variables. Onsite investigations began in May 1983 and continued until July 1985. This report documents the findings made during this period.

\section{Purpose and Scope}

The purpose of this report is to (1) describe the hydrogeology of Franklin Lake playa, and (2) provide estimates of ground-water discharge that occurs at Franklin Lake playa as bare-soil evaporation and as evapotranspiration through phreatophytes. These estimates of discharge, and measurements of water-table altitudes, are useful for refining the model presented by Czarnecki and Waddell (1984). In that model, the estimated discharge at Franklin Lake playa represented 65 percent of the total discharge. An accurate estimate of discharge at Franklin Lake playa is, therefore, essential to produce an accurate model of ground-water flow and to estimate transmissivity values upgradient from Franklin Lake playa. The scope of this report is limited to the characterization of the hydrology of Franklin Lake playa in the context of ground-water discharge rates, flow direction, and hydrologic properties affecting ground-water movement.

\section{Acknowledgments}

The logistical help and information provided by Fred Johnson, American Borate Company is appreciated. Useful suggestions related to this work were provided by E.P. Weeks (unsaturated-zone modeling; barometric efficiency), I.J. Winograd (playa hydrogeology), and F.E. Rush (discharge from pheatophytes) of the U.S. Geological Survey.

\section{Previous Work}

In their study of the hydrology of the Amargosa Desert, Walker and Eakin (1963, p. 23) provided a very approximate estimate of the rate of evaporation at Franklin Lake playa (known also as Alkali Flat). Their estimated evaporation rate of $0.3 \mathrm{~m} / \mathrm{a}$ was based in part on recharge estimates for the Amargosa Desert using an empirical procedure developed by Eakin and others (1951). Calzia and others (1979) did later work, in which a single hole was drilled near the center of the playa by a reverse-circulation process and drill cuttings were logged. The purpose of this hole was, in part, to characterize the mineral potential of the playa ground water and sediments, particularly for lithium content. These cuttings later were analyzed by Pantea (1980).

Several wells were drilled at the southern end of the playa (Fred Johnson, American Borate Co., oral commun., 1983) to recover gold and silver thought to be dissolved in the playa waters. At least 12 holes were drilled between 1978-80, ranging in depth from 3 to $17 \mathrm{~m}$. No gold or silver was found. However, some of these wells were used in this study to obtain hydrologic and hydrochemical data.

Regional analyses of the ground-water-flow system that includes Franklin Lake were made by Rush (1970), Winograd and Thordarson (1975), Waddell (1982), Czarnecki and Waddell (1984) and Czarnecki (1985). However, none of these efforts involved direct measurements of hydrologic properties at Franklin Lake playa.

Previous investigations of selected playas in the Western United States are summarized by Motts (1970) in one of the most comprehensive publications 


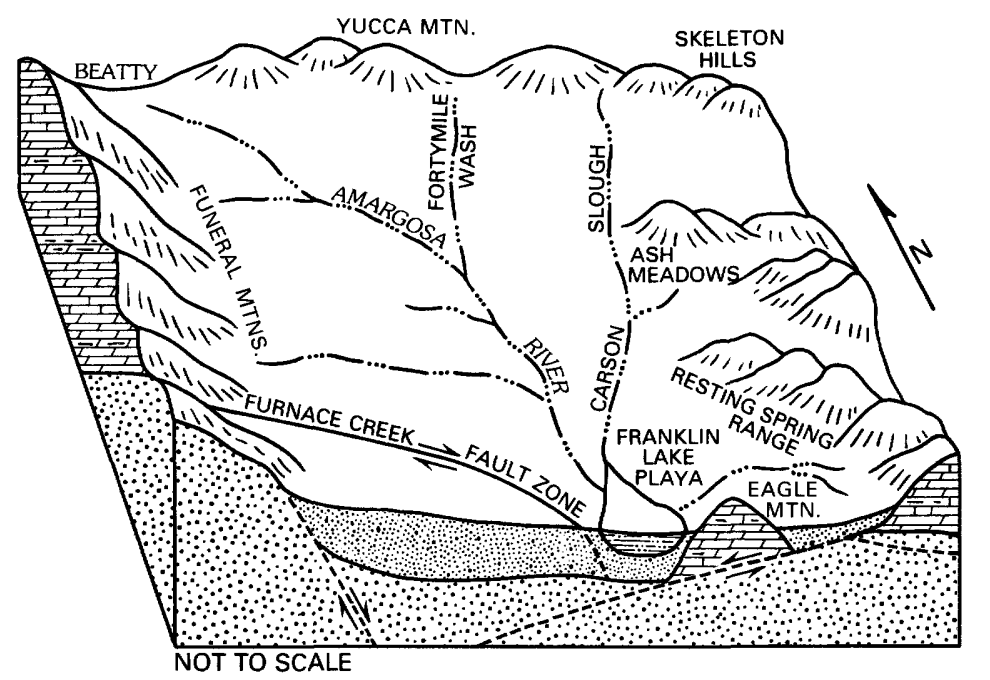

EXPLANATION

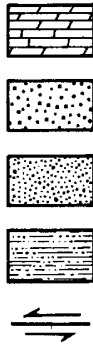

Limestone, dolomite, argillite

Crystalline bedrock, volcanics

Alluvium and colluviumGravel, sand and silt

Playa sediments-Clay and silt

Fault-Dashed where

approximately located. Arrows indicate relative movement

Figure 2. Generalized structure and lithology in the Franklin Lake playa study area.

on the subject. Playas have been classified using various criteria: (1) soil-surface type (Stone, 1956; Neal, 1965a); (2) hydrologic characteristics (Snyder, 1962; Motts, 1965) (3) degree of wetness (Thompson, 1929); (4) mineralogy (Langer and Kerr, 1966); (5) air-photo characteristics (Neal, 1965b); and (6) presence or absence of salt or lime pans (Jaeger, 1942).

Playas typically exhibit four characteristics (Motts, 1970, p. 9): (1) An area that occupies a basin or topographic valley of interior drainage; (2) a smooth, barren surface that is extremely flat and has a small topographic gradient; (3) an area that infrequently contains water, which occurs in a region of low rainfall where evaporation exceeds precipitation; and (4) an area that is fairly large in size (generally more than 2,000 to $3,000 \mathrm{ft}$ in diameter). The barren surface is a distinctive feature of "playas"; in Spanish, playa means shore or beach (Motts, 1970, p. 9).

Playas occupy the lowest parts of enclosed basins and typically are dry most of the time; the term "playa lake" is used when water temporarily covers the surface. If water frequently is present on the playa, the term "lake" is appropriate (Motts, 1970, p. 9). Motts (1970, table 2, p. 11) used the concept of flooding ratio to characterize playas; the flooding ratio is the fraction of the year that a playa is covered by water. A playa would have a flooding ratio of 0.25 or less.

Because playas occupy the lowest parts of desert valleys, they commonly are areas where ground water discharges. Most recharge occurs through stream channels that cross alluvial slopes and desert flats extending to the playa. Motts (1970, p. 13) discussed the concept of a "bypass playa," which occurs where part of the ground water discharges within the playa area and part of the ground water moves downgradient to discharge at lower topographic elevations. He also noted that discharge of ground water from playa areas may occur in three ways: (1) Directly through the playa surface by capillary evaporation from shallow aquifers or by artesian flow from deeper aquifers; (2) from springs that commonly occur near the gradations from coarse-grained bajada sediments to fine-grained playa sediments; and (3) from evapotrans-piration by phreatophytes (Motts, 1970, p. 13).

\section{GEOHYDROLOGY OF FRANKLIN LAKE PLAYA AND VICINITY}

Franklin Lake playa is at the discharge end of the ground-water-flow system of the Amargosa Desert; the playa covers an area of about $14.2 \mathrm{~km}^{2}$ (figs. 1 and 2). Ground water flows through alluvial sediments underlying the Amargosa Desert. The alluvium probably overlies carbonate rocks, but no drill holes fully penetrate the alluvium to provide confirmation of that possibility (Czarnecki and Waddell, 1984, p. 7). Wells drilled in the Amargosa Desert principally are completed in an alluvial aquifer and rarely exceed $150 \mathrm{~m}$ in depth. However, initial estimates of alluvial thickness in the Amargosa Desert inferred from vertical electrical-resistivity soundings (Greenhaus and Zablocki, 1982) and seismic refraction surveys (H.D. 
Ackerman, U.S. Geological Survey, written commun., 1986) indicate potential depths to bedrock (possibly carbonates) of about 1,000 to $1,800 \mathrm{~m}$. Fine-grained lakebeds, playa deposits, or marsh deposits are present within the alluvium, principally near Ash Meadows (Walker and Eakin, 1963; Naff, 1973; Claassen, 1985). A block diagram showing the general spatial relations between sediment types is shown in figure 2 .

\section{Playa Surfaces}

Types of playa surfaces have been used by various investigators (Neal, 1965a; Langer and Kerr, 1966; Neal and Motts, 1967; Hagar, 1970) to characterize playas. Several surface types occur on Franklin Lake playa and the near vicinity: (1) hard, compact; (2) soft, puffy, porous; (3) salt pan; (4) stream channel; (5) vegetation; and (6) desert pavement. The location of these various surfaces is shown in figure 3 .

\section{Hard, Compact Surface}

Hard, compact surfaces occur in the southern part of the playa and along the margins of stream courses. These surfaces commonly were used for roads to traverse the playa. Wells were installed at the study sites designated as the central site and the south-central site (fig. 4) because the proximity of the hard, flat surface near these two sites facilitated motor-vehicle travel. These surfaces typically exhibit mud cracks that form polygons as much as $0.1 \mathrm{~m}$ in length (see photograph in fig. 5A). Occasionally, these surfaces might be dissected by small, braided stream channels. Areas with the hard, compact surface generally show little or no relief (Motts, 1970, p. 73). The hard, compact surface covers approximately 10 percent of Franklin Lake playa.

Hagar (1970) reasoned that these surfaces formed in areas where the water table was substantially deep, because water was lacking to swell the clays or to precipitate salts. However, piezometers installed through this surface at the central study site penetrated the water table at about $1.8 \mathrm{~m}$ below land surface.

The cause for this type of surface at Franklin Lake playa might be linked to cementing of clay grains by infrequent runoff. Motts (1970, p. 134) observed that “***flooding keeps the playa crusts in a permanent, compact, hard state***." Similar hard, compact clay sediments also are present in the stream-channel surfaces in the Amargosa River channel, but they exhibit more irregular, hummocky surfaces. The hard, compact surfaces are light buff in color.

\section{Soft, Puffy, Porous Surface}

Initial reconnaissance trips across Franklin Lake playa by four-wheel drive vehicles were made through extensive areas with soft, puffy, porous surfaces, often causing the truck tires to sink $0.3 \mathrm{~m}$ or more, particularly when underlying moist mud was encountered. About 40 percent of Franklin Lake playa is covered by this type of surface, dark buff to reddish brown in color. Often, mostly clay and silt can be observed under these surfaces after removing the first 0.2 to 0.5 $\mathrm{m}$ of loose, silt-size material. The top surface material generally consists of a thin salt crust about $1 \mathrm{~cm}$ thick, which forms an intricate network of polygons (fig. $5 B$ ) as much as $0.2 \mathrm{~m}$ across, and has a local hummocky relief as much as $0.1 \mathrm{~m}$. In addition to the surface crust, gravels as much as $2 \mathrm{~cm}$ long occasionally were observed.

Hagar (1970) indicated that the soft, puffy, porous surface may result from capillary ground-water movement, which causes salts to precipitate and clays (such as montmorillonite and illite) to swell. In his work at Coyote Lake, California, Hagar (1970) observed soft, puffy, porous surfaces in conjunction with underlying dry, hard clay, where depths to the zone of saturation were greater than $3 \mathrm{~m}$; he suggested (p. 79) that “***surface water probably moves through the surface layer or loose, porous clays and essentially is perched above the more compact clays that lie beneath***."

Motts (1970, p. 35) observed that puffy ground at Coyote playa has a hard, compact surface and “***may be topographically higher than the surrounding playa surface, thus not subject to frequent flooding***." Leveling surveys and visual observations determined that this is the case at Franklin Lake playa.

Observation well GS-18 at the south-central measuring site (fig. 4) was drilled through a soft, puffy, porous surface; moist clays (olive green to olive gray in color) were penetrated at a depth of about 3.5 $\mathrm{m}$. Well GS-18 was drilled to a depth of $8.2 \mathrm{~m}$; neutron logs of GS-18 show increasing soil-moisture content with depth through the unsaturated zone. The water table at GS-18 probably is not perched (see potentiometric-surface map, fig. 10, later in the report) because other distant wells have about the same water-table altitude. 


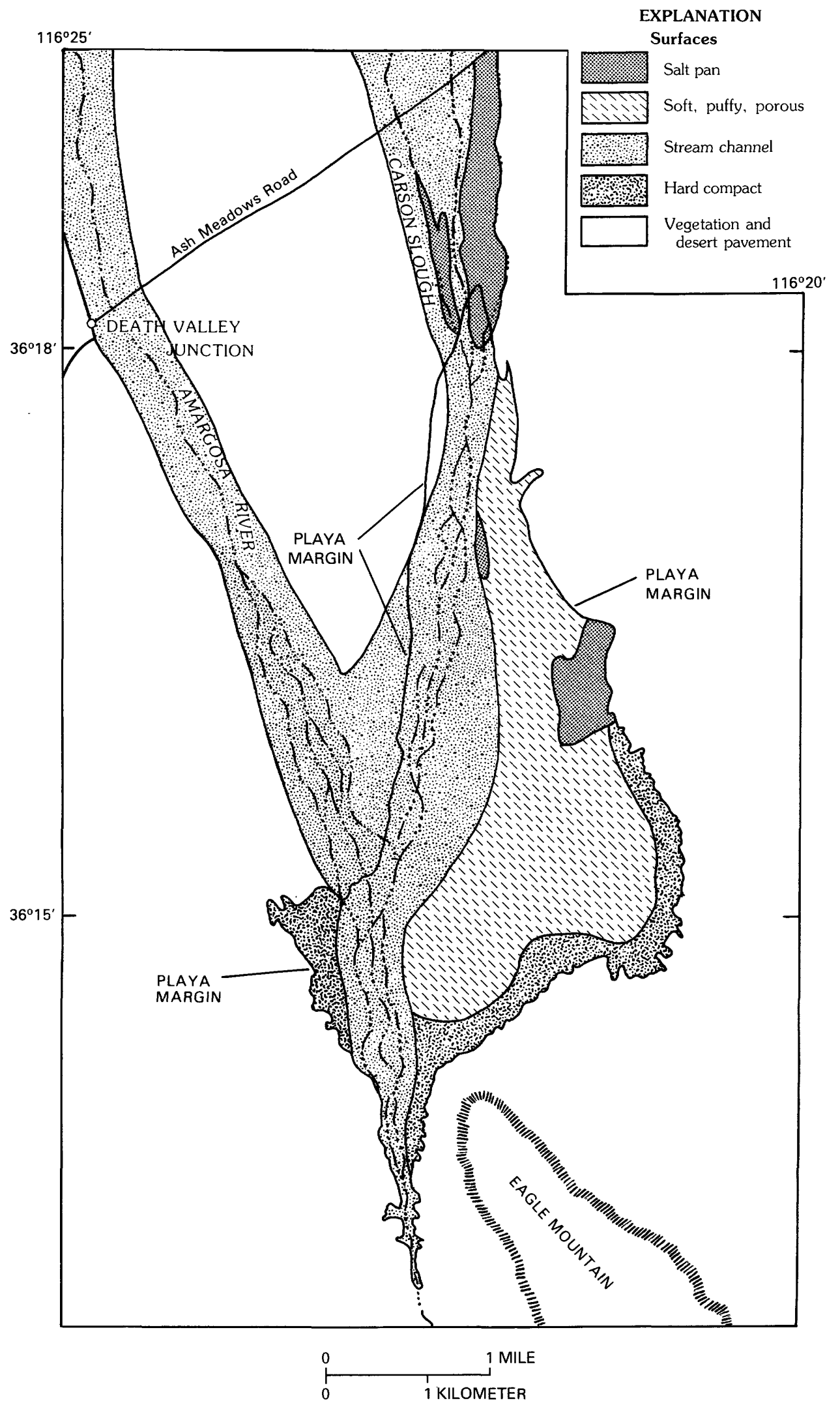

Figure 3. Distribution of Franklin Lake playa surfaces. Surface boundaries are approximate. 


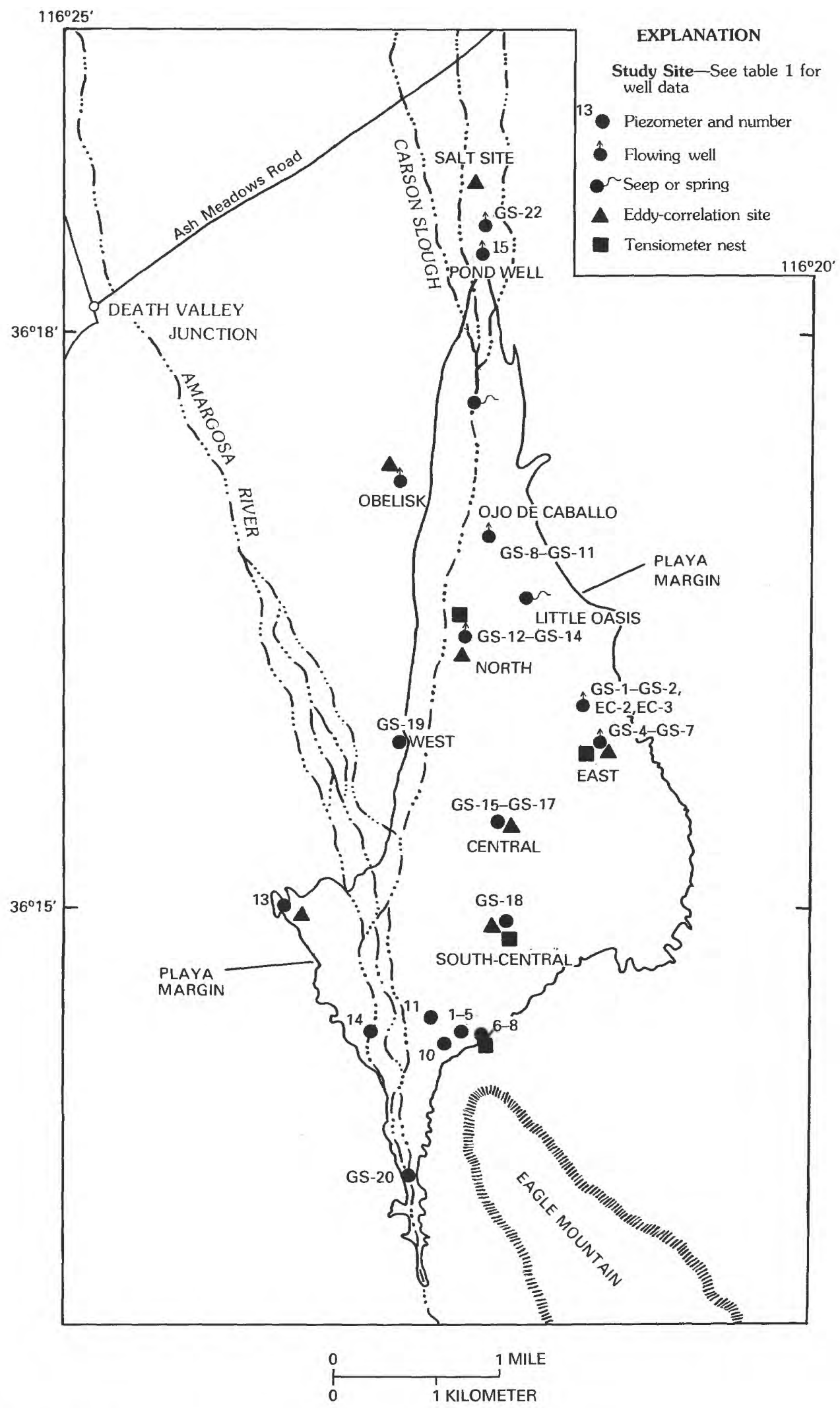

Figure 4. Study sites at Franklin Lake playa. 


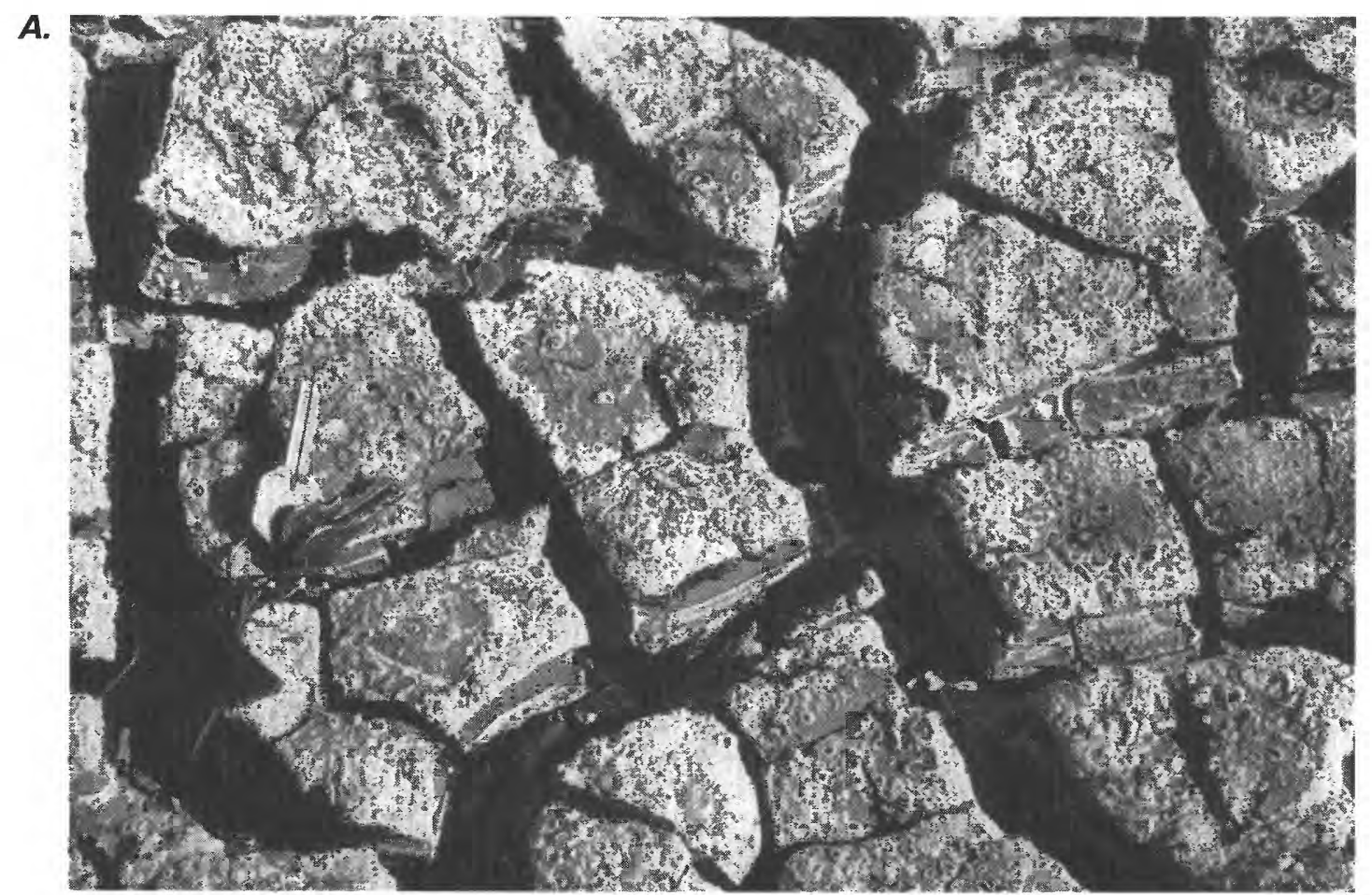

B.

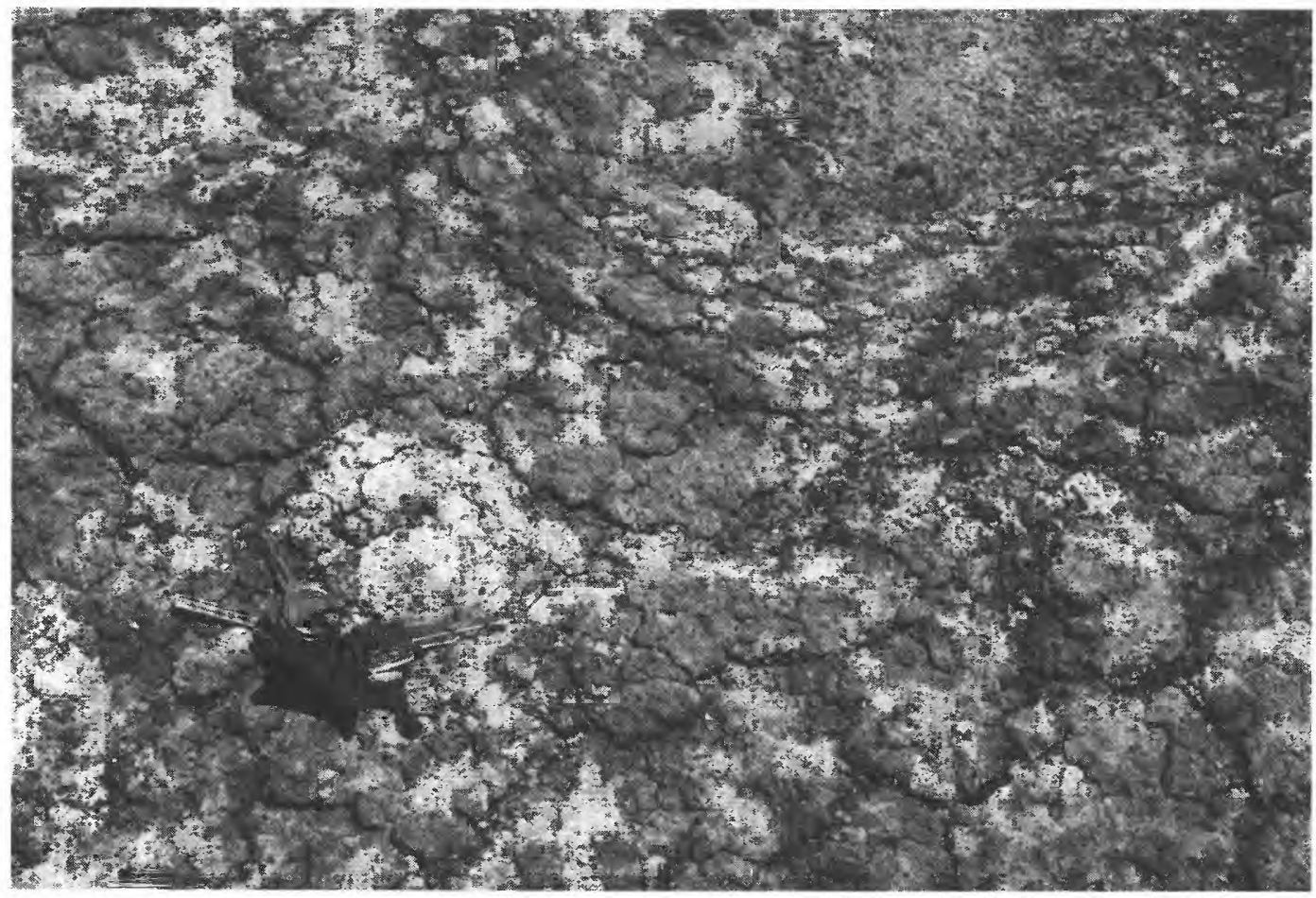

Figure 5. $A$, Mud cracks on stream-channel surface, and $B$, mud cracks and soft, puffy, porous surface. 


\section{Salt-Pan Surface}

The soft, puffy, porous surface described previously contains a thin veneer of salt crust; however, many areas, particularly to the north and east, are covered by a continuous, white salt crust (fig. 6A). These salt-pan areas tend to be the wettest on the playa and have very moist underlying clays approaching saturation at $0.1 \mathrm{~m}$ or less below the salt-crust surface. These conditions make driving treacherous and walking difficult.

These salt crusts consist of interlocking salt crystals, many of which have botryoidal shape. Crystals taste like halite, but they have not been analyzed for chemical content. Similar salt-crust surfaces were observed by Hunt and others (1966, p. B15-16) over large areas of Death Valley; Death Valley is located at a lower altitude in the same surface-water-flow system as Franklin Lake playa, with flow occurring in the Amargosa River.

Wells GS-1, GS-2 (north of the East site, fig. 4), the Pond well (well 15) and wells at Ojo del Caballo (GS-8, GS-9, GS-10, and GS-11) were constructed through salt-pan surfaces. The deepest of these wells, GS-8 $(10.0 \mathrm{~m})$, produced water that rose $2.28 \mathrm{~m}$ above land surface in an extension of the well casing. Sediment grain sizes immediately below the salt crust ranged from clay to fine sand at these two sites; however, well GS-8 was drilled through approximately $8.5 \mathrm{~m}$ of olive-green, indurated clay, underlain by stream gravels (as much as $1 \mathrm{~cm}$ in diameter), from which water flowed readily. Although well GS-10 (fig. 4) terminated in indurated clays, this well had water levels measured as high as $1.12 \mathrm{~m}$ above land surface. The presence of salt-pan surfaces is hypothesized to coincide with an underlying shallow confined gravel aquifer that causes upward leakage of ground water through a confining clay layer to the surface.

Additional drill holes would be required to confirm the occurrence of a confined gravel aquifer beneath the salt-pan surface; however, the Pond well (well 15) is a flowing well north of the Ojo del Caballo site; it is located near the stream channel in Carson Slough (fig. 4). Between well 15 and the Ojo del Caballo site is an abandoned ranch site that has perennial surface water, fed by a spring. Between the Ojo del Caballo site and wells GS-1 and GS-2 is another surface seep or spring (referred to as the "Little Oasis"), located in a stream channel that is not a salt-pan surface. This lack of a salt-pan surface may result from periodic flushing of the salts by floods. The water discharging from the pond well and the assorted springs and seeps likely derive their water from a confined gravel aquifer extending northward toward Carson Slough.

The salt pan occurs near and along the margins of the playa. Salt concentration in the salt pan changes seasonally, with winter months having the heaviest salt buildup, resulting in part from a higher potentiometric surface and an absence of flushing rains. Spring, summer, and fall months produce (1) stronger winds that deflate the salt-pan surface, (2) rains and floods that wash away the salt crust, and (3) a lower potentiometric surface.

\section{Stream-Channel Surface}

Two major streams, the Amargosa River and Carson Slough (fig. 2) enter Franklin Lake playa from the north and northwest and subsequently merge on the western margin of the playa. Channels for these streams have a very hummocky, hard, compacted clay surface interrupted by elongated phreatophyte mounds (fig. 7), interspersed stream-gravel and dune-sand deposits, and sinuous, braided stream channels. The maximum total width of the stream-channel surface is about $200 \mathrm{~m}$, with individual channels as wide as $10 \mathrm{~m}$. Local relief along the major stream channels in places exceeds $1.2 \mathrm{~m}$ at bank cuts; phreatophyte mounds commonly are 0.6 $\mathrm{m}$ high and $2 \mathrm{~m}$ long.

Surface water was observed during July and August 1984 in the Amargosa River and Carson Slough after heavy thunderstorms occurred in the Franklin Lake playa area. Carson Slough was observed to flow into the Amargosa River channel during January to March 1985; this flow had stopped by at least June 1985 as evapotranspiration increased. North of Death Valley Junction, the Amargosa River had no water flowing in its channel during this period. This difference between the flowing Carson Slough and the nonflowing Amargosa River likely resulted from spring discharge at Ash Meadows coupled with decreased evapotranspiration during winter months causing runoff into Carson Slough. However, many puddles remained in the Amargosa River channel as a result of this flow. These puddles (as much as $1 \mathrm{~m}$ deep) persist throughout the year despite strong winds and evapotranspiration. 
A.

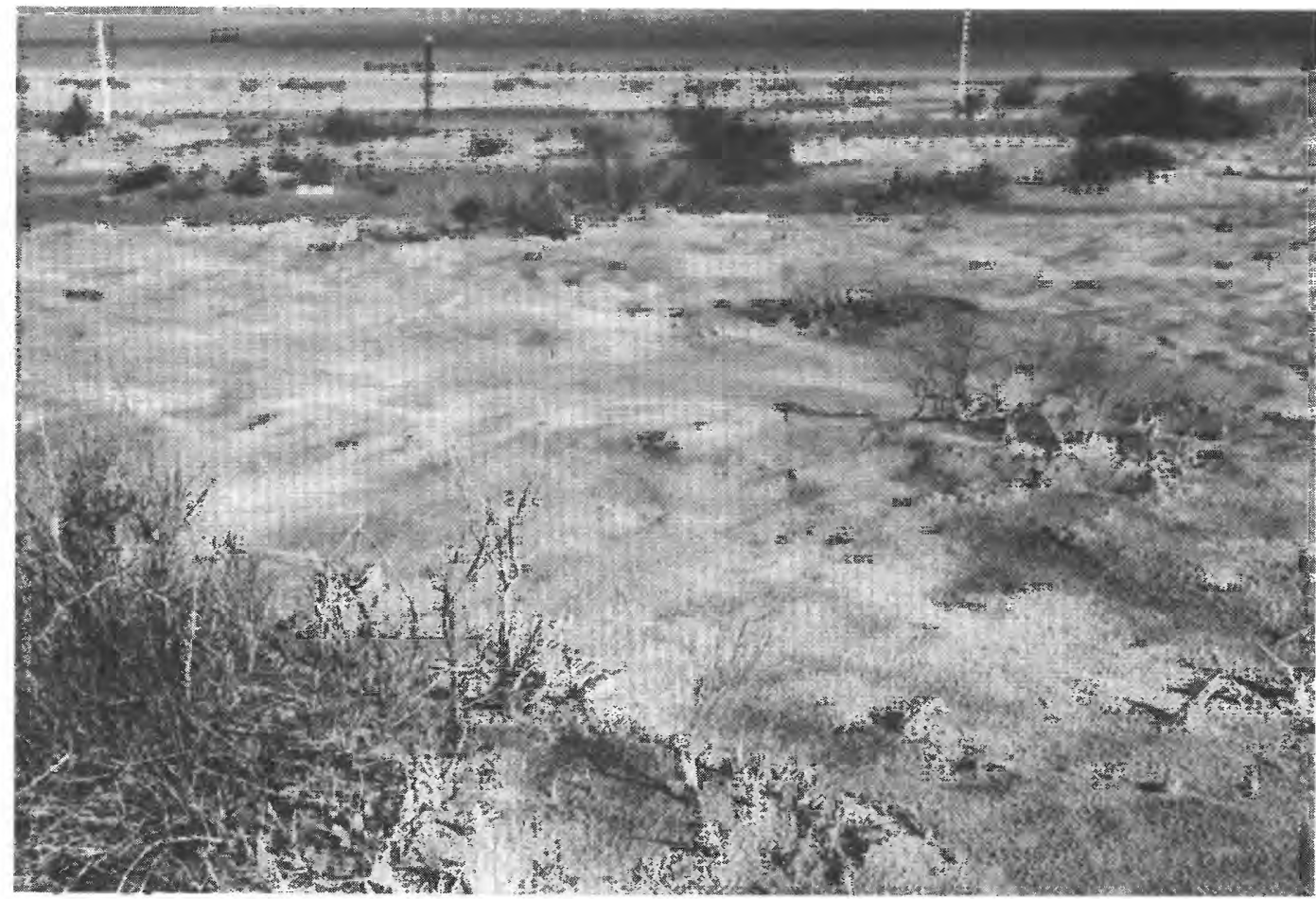

B.

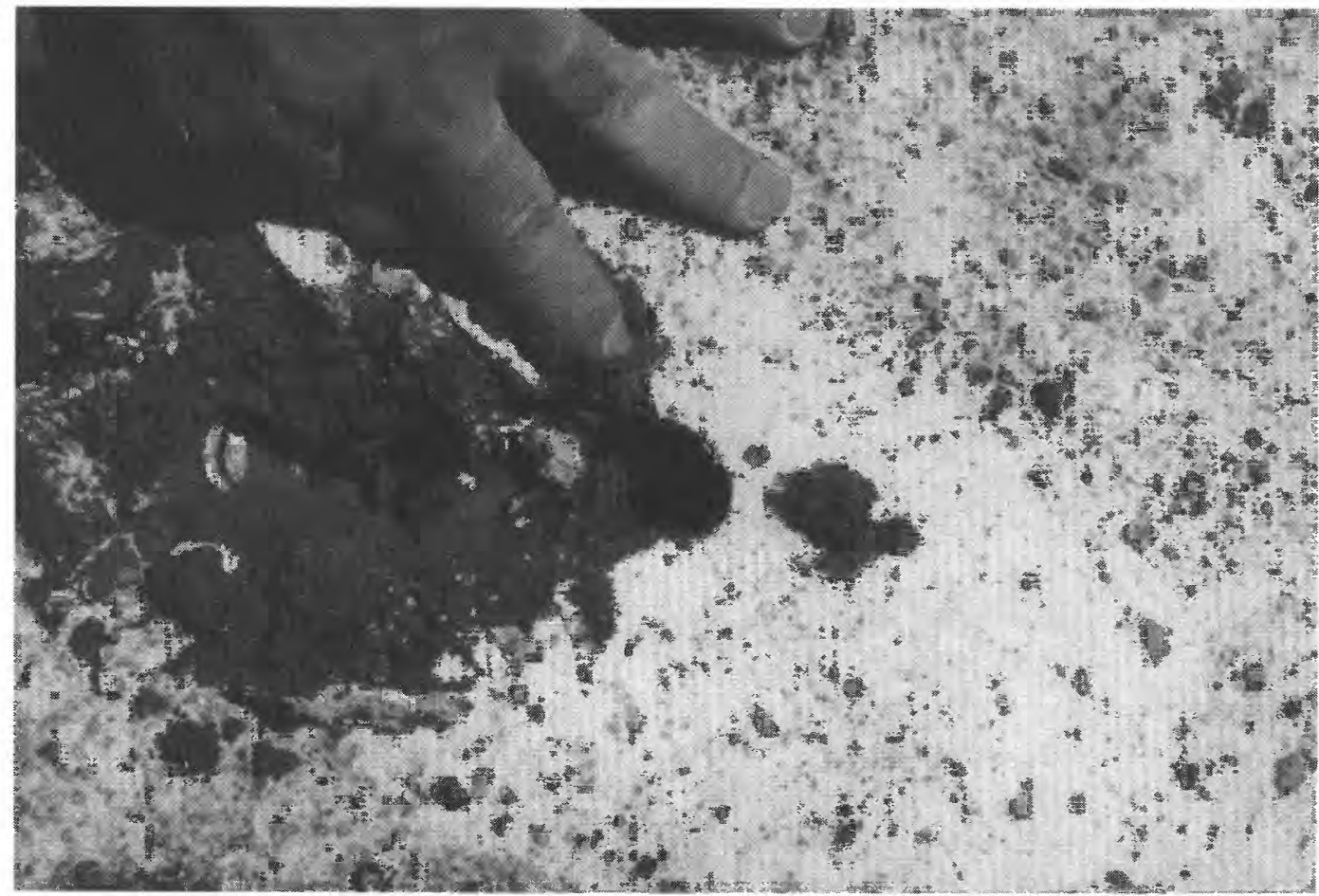

Figure 6. Salt pan crust $A$, at Ojo del Caballo site; and $B$, surface at East study site.

Stream channels probably focus recharge during periods of surface-water flow. Temperature measurements in well 10 (see temperature-measurement profile of fig. 32B) made during March 1985 indicate a decrease in temperature with depth (the only profile to show this for this period), which may indicate recharge conditions. The temperature profile in this case is concave upward (see idealized temperature profile of fig. 31), which indicates that colder water has infiltrated downward, decreasing the temperature 


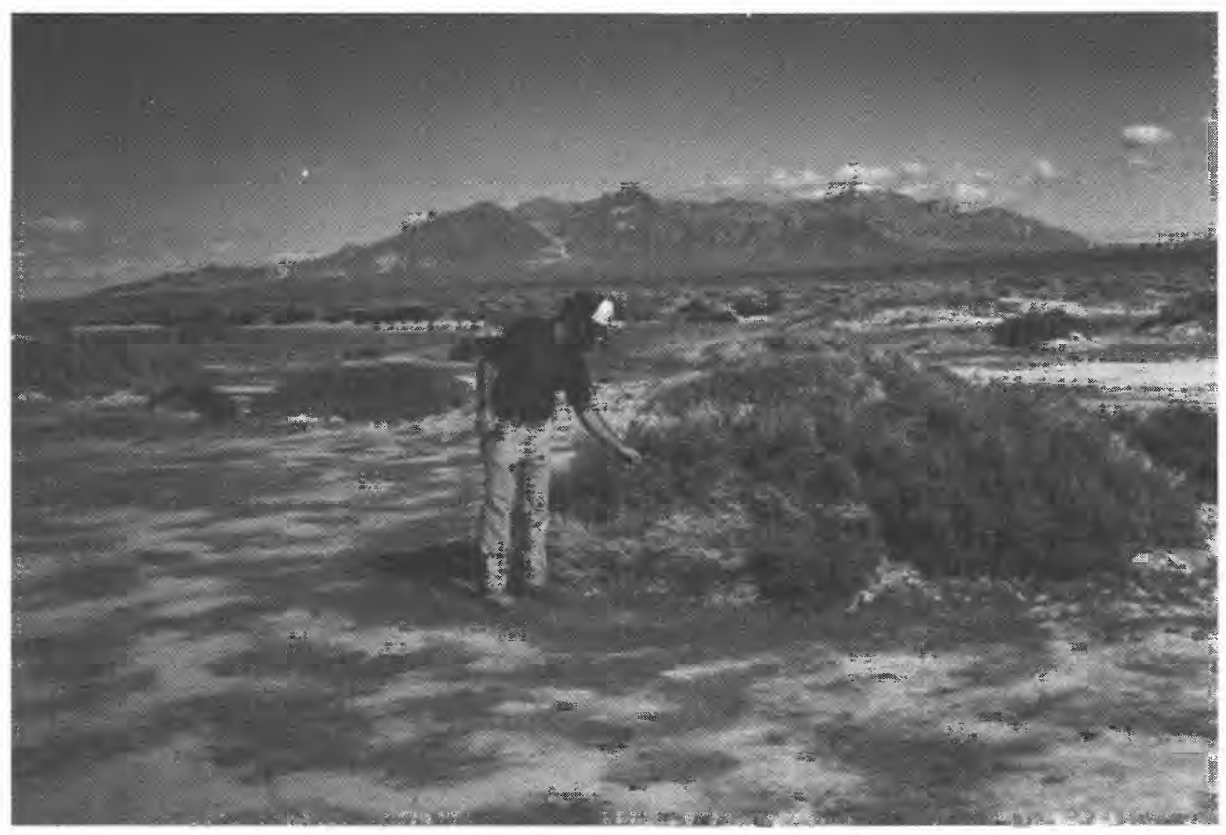

Figure 7. Phreatophyte mound. Phreatophytes are plants that habitually obtain their water from a shallow water table or ground-water discharge. The mound forms as wind-blown sediment is entrapped by the plant. The plant will grow onto the entrapped sediment to keep from being buried. The large plant next to the author is saltbush (Atriplex parryi).

that would be expected at an equivalent depth under ambient conditions for the geothermal gradient. Well 10 is located adjacent to the Amargosa River, and water did flow in the river from January through March 1985.

\section{Vegetation Surface}

Vegetation is generally limited to beyond the margins of the playa and consists of sparsely distributed phreatophytes and xerophytes. Phreatophytes are plants that habitually obtain their water in part from the saturated zone and are indicators of a shallow water table and ground-water discharge. Xerophytes derive their water from the unsaturated zone, are ubiquitous throughout the Amargosa Desert, and can coexist with phreatophytes. The stream-channel areas along the west side of the playa contain moderately spaced (10 to $40 \mathrm{~m}$ apart) phreatophyte mounds primarily covered with greasewood (Sarcobatus vermiculatus), seep weed (Suaeda fruticosa) (Munz, 1974, p. 370), and saltbush (Atriplex parryi) (fig. 7). Ground cover by these plants ranges from 1 to 5 percent of the total surface area; total plant height rarely exceeds 1 $\mathrm{m}$. On eastern and northern playa margins, saltgrass (Distichlis stricta) grows to a height of about $15 \mathrm{~cm}$, covering as much as 50 percent of the immediate land surface. Salt crust also occurs on the eastern and northern playa margins.

Saltgrass and a form of tule (Scirpus robustus) (Munz, 1974, p. 903) grow at the Ojo del Caballo study site where springs issue from the playa sediments (fig. 8). Saltgrass also occurs at the Little Oasis site.

\section{Potentiometric Surface}

Knowledge of the configuration of the potentiometric surface is required to determine the potential direction of ground-water flow. If transmissivity can be estimated, then a quantitative estimate of ground-water flux can be made. A quantification of the potentiometric gradient, both vertically and horizontally, can lead to estimates of ground-water discharge and lateral flow.

The potentiometric surface is shown in figure 9 for the Amargosa Desert. Ground-water flow generally is toward the south, with discharge occurring at Franklin Lake playa. Potentiometric-surface contours for Franklin Lake playa are shown in figure 10. A summary of all potentiometric data is listed in table 1 . Hydraulic-head data were collected from a network of 20 piezometers (GS-1 through GS-20, fig. 4) installed on or near the playa and from 15 unused wells found 


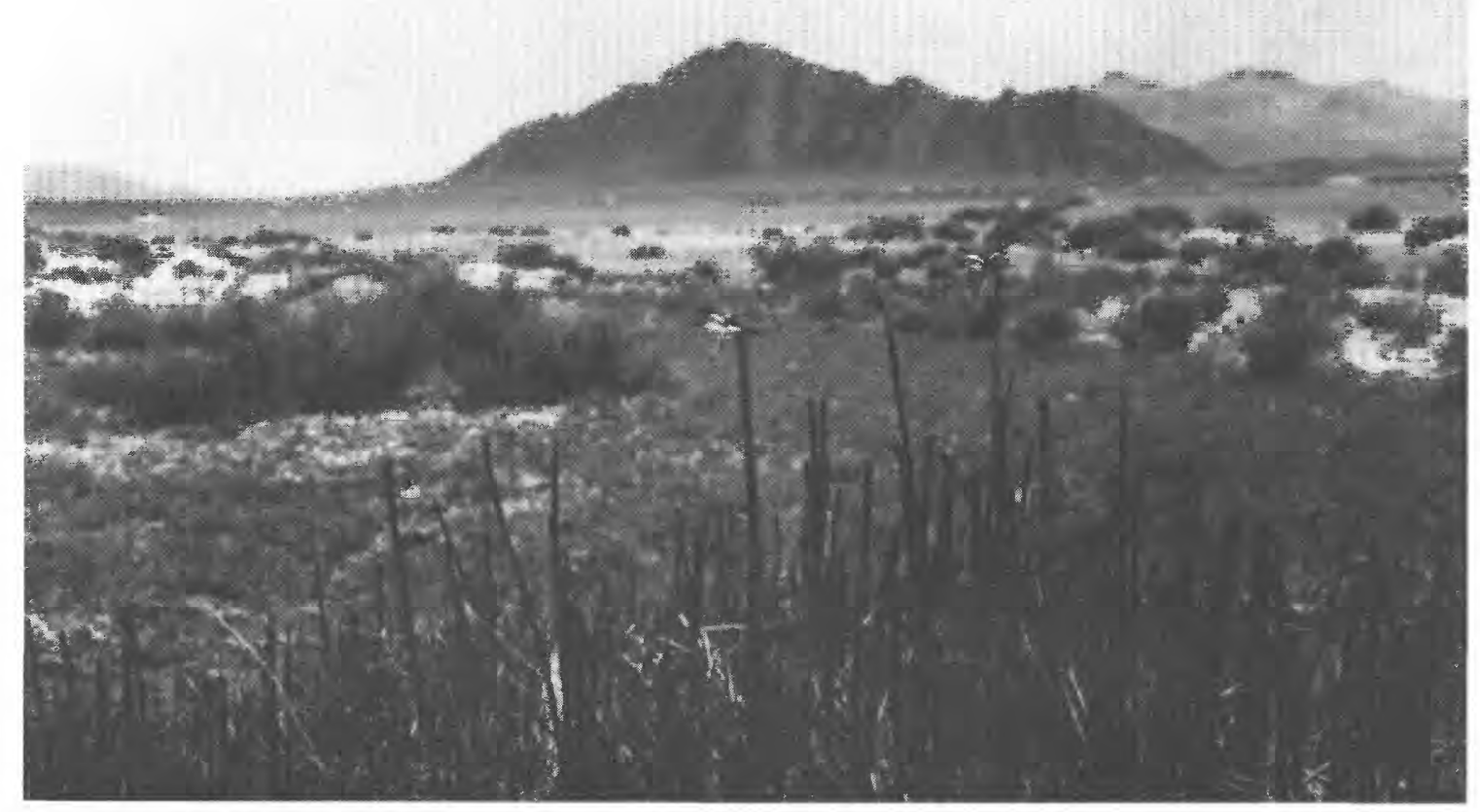

Figure 8. Ojo del Caballo study-site vegetation. Dragon flies are perched on Scirpus robustus, a form of tule. Saltgrass (Distichlis stricta) forms a low-lying ground cover in the background. Also in the background are greasewood bushes (Sarcobatus vermiculatus).

on or near the playa. Wells GS-1 through GS-20 were installed in nests at different locations to obtain hydraulic-head measurements at various depths below land surface at a specified site. A typical piezometer nest is shown in figure 11. Potentiometric contours (fig. 10) represent the temporal averages for the shallowest wells at any given site.

All piezometers constructed during this study are designated with a "GS" prefix and are numbered consecutively, north to south, and east to west. Well numbers not preceded by a prefix represent wells that existed prior to this study and were numbered in the order in which they were found. Missing well numbers $(2,4,9$, and 12$)$ represent uncased boreholes that were found at Franklin Lake playa but were not used in this study because of problems with inflowing surface water resulting from infrequent, major storms.

The potentiometric surface in the northeastern section of Franklin Lake playa is at or above land surface. Differences in altitudes between the land surface and the potentiometric surface are shown in figure 12 , based on 13 data points. Confined conditions exist in the northern part of the playa, with increasing depth to water occurring toward the south. Water levels in numerous wells were measured; these levels were shown as altitude of potentiometric surface versus time by Czarnecki (1990, figs. 3A-K). Measurements were made by using a steel tape; measurement precision generally is to within $0.002 \mathrm{~m}$. Flat hydrographs are typical of wells completed in transmissive sediments; hydrographs showing frequent water-level fluctuations indicate tighter sediments.

Water levels were recorded continuously using a Stephens F-type recorder and float in wells 5, 11, and GS -4 to obtain potential data for estimating evapotranspiration. Wells 11 and GS -4 had less than $0.002-\mathrm{m}$ variation in water-level altitude over 2 weeks; whereas, the water level in well 5 varied in direct response to barometric-pressure changes by as much as $0.06 \mathrm{~m}$ (fig. 13).

Increasing hydraulic head occurs with depth at several of the piezometer nests. Vertical-gradient calculations for several sites are presented in Czarnecki (1990, figs. 5A-E, 4G) where a range in positive values of vertical hydraulic gradients $(0.1$ to 0.8 , indicating upward flow) is shown. In contrast, the range in 


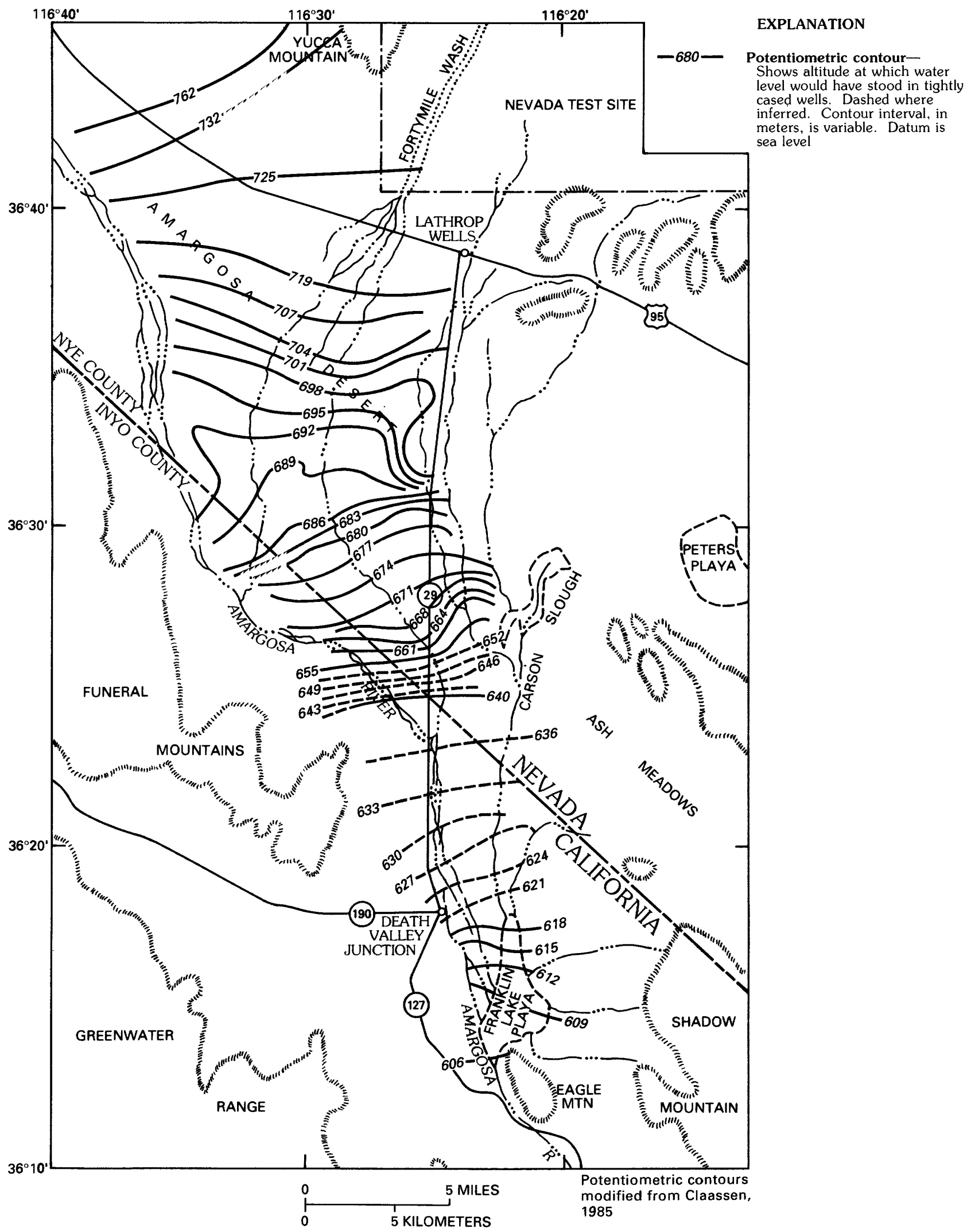

Figure 9. Potentiometric surface of the Amargosa Desert. 


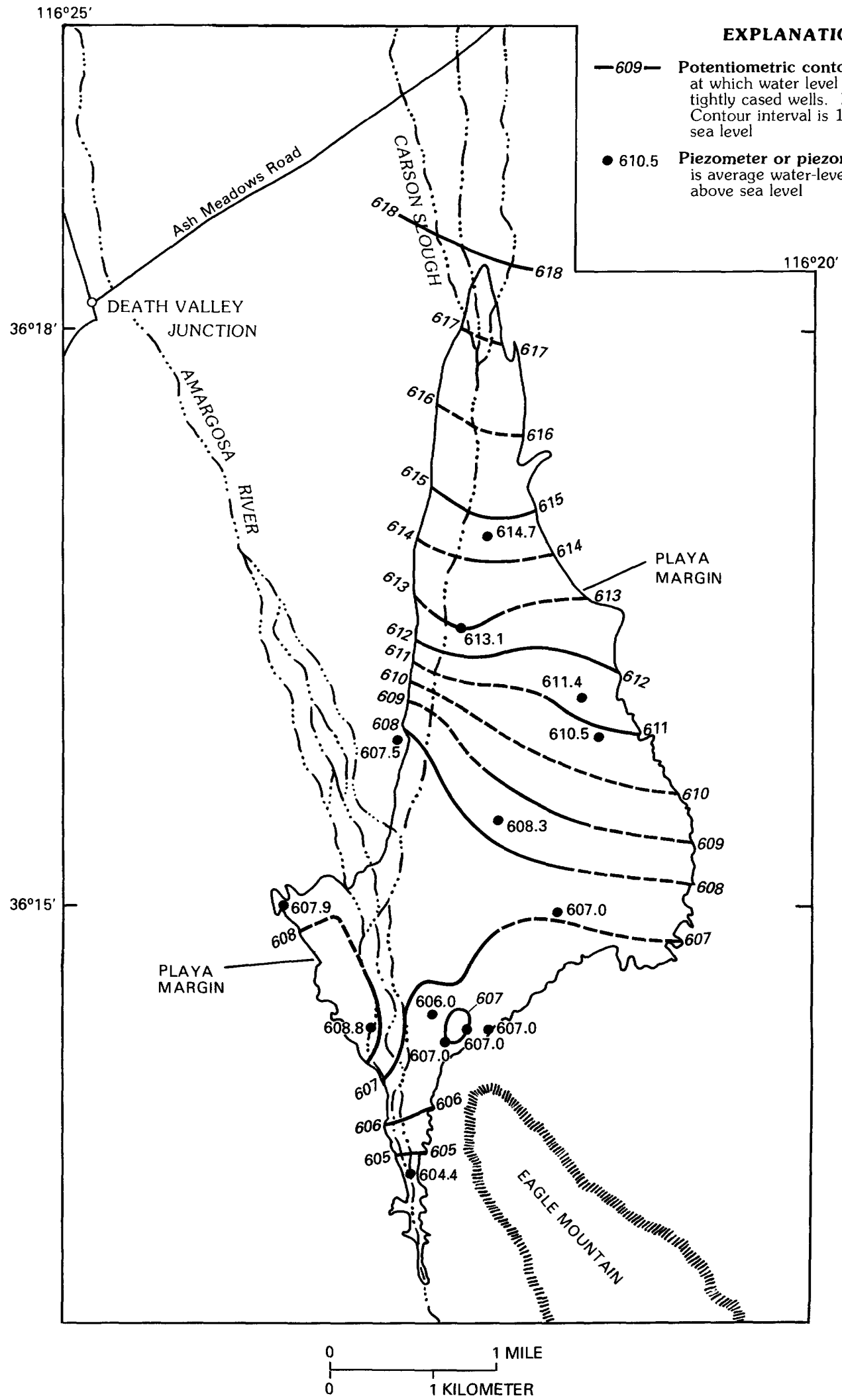

Figure 10. Potentiometric surface at Franklin Lake playa. 


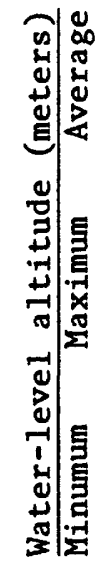

$4+\infty \stackrel{0}{0}$

- 占送告

㝳为出

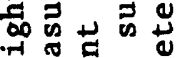

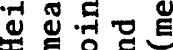

(1) 요욤

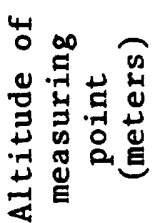

$\infty$ 出 क

단.

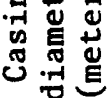

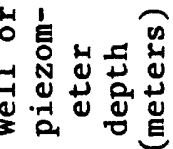

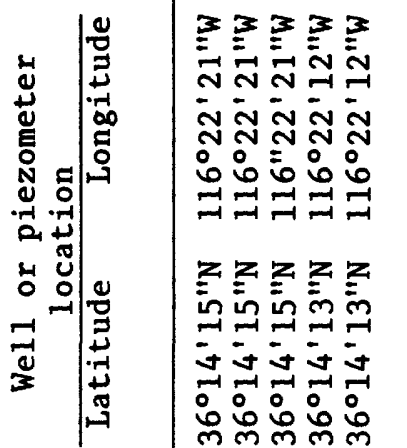

능어음

$\infty$ ن

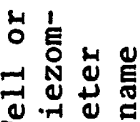

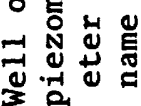

- $m$ in 0

$\infty$ 엄ㄷㄷㅁㄷㄱ

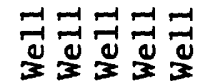

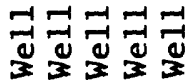

워ำษ์

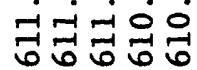

ษักิด

0

을

๓ำㅇํำ

mi் $\dot{\sim} \dot{0}$

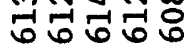

ติํํㅇํำ

$\infty \dot{0} 0 \dot{0} \dot{0}$

응ㅇㅇㅇㅇㅇㅇㅇ

$\infty \underset{\infty}{\infty} \circ \stackrel{-1}{\infty}$

$\dot{0} \dot{0} \dot{0}$

6

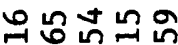

ㄷํㄴํㅇㅇㅛ

于 $\dot{\sim} \dot{\sim} \dot{\infty}$

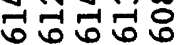

$\infty 0_{0}^{\infty} \tilde{0} 0$

ㅇํㅇㅇㅇㅇㅛ

ํำำก

ํำ ํำ ำ

거요

0ंतिं

बै

도어쇼.

mi-1

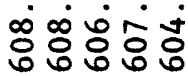

艝

ำำำำ

tơ

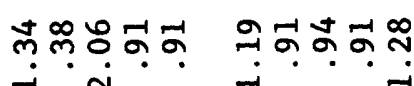

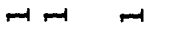

$-1 \dot{m}-\dot{-1}$

$\infty$ กิโ

ن $\dot{1} \dot{\infty} \dot{0}$

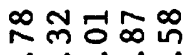

लिं

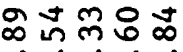
i $\dot{0}$

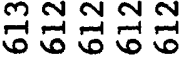

बढ

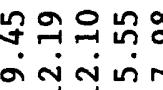

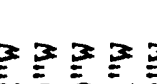

ฟิํํำำ

ฟัพับัต

ก. 0 \% 00

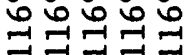

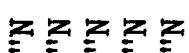

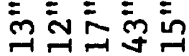

可可吉

त्र

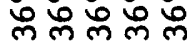

ํํㅇํํㅇํํㄴำ

ฟักั้งสัก

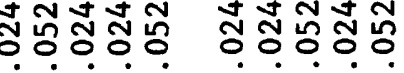

an in तं

3

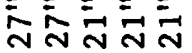

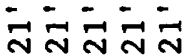

$000 \% 0$

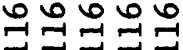

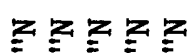
ํํㅇํํㅇํำ

io io in in

-1

లో
$-1$

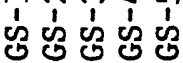

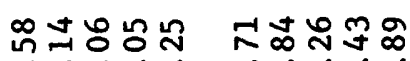
iெ $\dot{0} \dot{0}$

3 กับำสำ ㄱำ

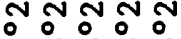
\%

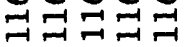

z飞飞飞更 슬ㅇㅇㅇㅇㅇㅇㅇㅇ in in

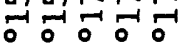
లొ

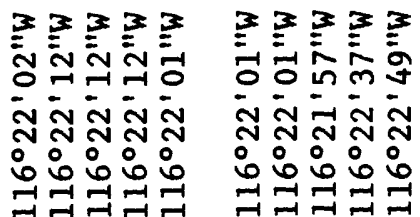

z更军文 ㅇํㅅㅊํํำ त̄o

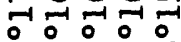
ర్లి

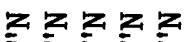

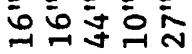
in in $=5 \mathrm{~m}$ ले ले ले

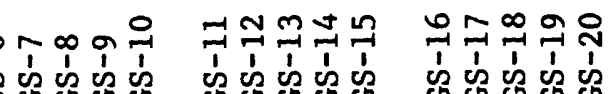

ิํํㅇํำ $\dot{0} \dot{0} \dot{0}$

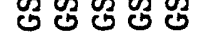




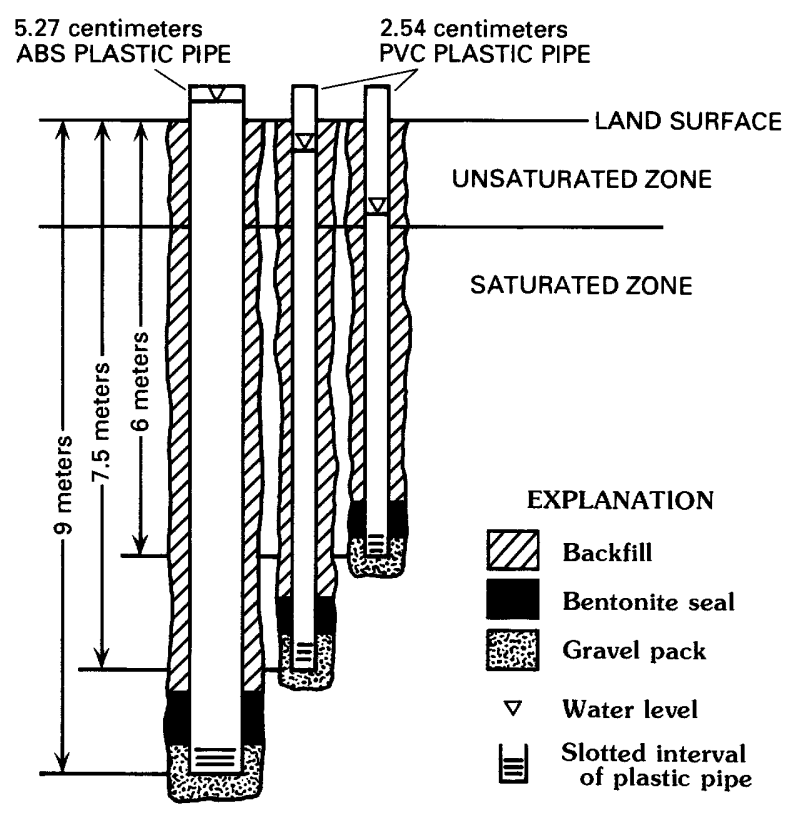

Figure 11. Typical piezometer nest construction.

horizontal hydraulic gradients estimated from potentiometric contours is 0.002 to 0.005 (fig. 10). This difference of two orders of magnitude between vertical and horizontal components of gradients, without considering differences in vertical and horizontal hydraulic conductivity, indicates that the horizontal component of flow may be insignificant when compared with the vertical component of flow. This assumption is presented in a subsequent section that uses the vertical gradient to estimate evaporation. The northern and eastern parts of Franklin Lake playa have flowing wells. Some of these wells, such as GS-8, flow at about $6 \mathrm{~L} / \mathrm{min}$.

\section{Transmissivity and Hydraulic Conductivity}

To calculate discharge using vertical-gradient estimates, the value of transmissivity needs to be known. As many independent methods as possible were used to estimate transmissivity at Franklin Lake playa. These methods include as follows: (1) pumped-well recovery tests; (2) falling-head injection tests; (3) falling-head permeameter tests performed on core; and (4) estimation of the effective pneumatic diffusivity and intrinsic permeability.

\section{Recovery Tests}

The Theis equation for aquifer recovery tests (Driscoll, 1986, p. 221) was used to estimate transmissivity using recovery data for wells 5 and 14 . This equation, relating transmissivity to residual drawdown is

$$
T=\frac{0.183 Q}{\Delta s} \log _{10}\left(t / t^{\prime}\right)
$$

where

$T$ is transmissivity, in meters squared per day;

$Q$ is the pumping rate, in cubic meters per day;

$s$ is the residual drawdown, in meters;

$t$ is the time since pumping started, in minutes;

and

$t^{\prime}$ is the time since pumping stopped, in minutes.

Hydraulic conductivity $(\mathrm{K})$ may be estimated by dividing the transmissivity by the saturated thickness $(T / b)$, or in this case, estimated by dividing the length of the open or screened section of the well, denoted as b.

Results for recovery tests for wells 5 and 14 are shown in figure 14 . The transmissivity was estimated to be $4.6 \mathrm{~m}^{2} / \mathrm{d}$ for well 5 and $43.5 \mathrm{~m}^{2} / \mathrm{d}$ for well 14 ; the hydraulic conductivity was estimated to be $0.54 \mathrm{~m} / \mathrm{d}$ for well 5 and $2.7 \mathrm{~m} / \mathrm{d}$ for well 14 . Some difficulty existed in selecting the late-time straight-line part of the recovery curve, particularly for the well-5 test. The slopes of the straight-line sections were estimated by taking the difference between two data points from the late-time part of each curve.

Appropriate usage of the previous equation requires that sufficient testing time be allowed, so that well-bore effects are minimized. Sufficient testing time may be determined from the relation (Weeks, 1978, p. 23):

$$
t>\frac{25 r_{c}^{2}}{T}
$$

where

$t$ is time, in days;

$r_{c}$ is the radius of the well, in meters; and

$T$ is aquifer transmissivity, in meters squared per day.

This time criterion represents the mininum time that pumping needs to occur during a test. Until the time indicated by the time criterion is exceeded, the pumped-well drawdown is dominated by well-bore storage effects, and the aquifer properties cannot be determined. 


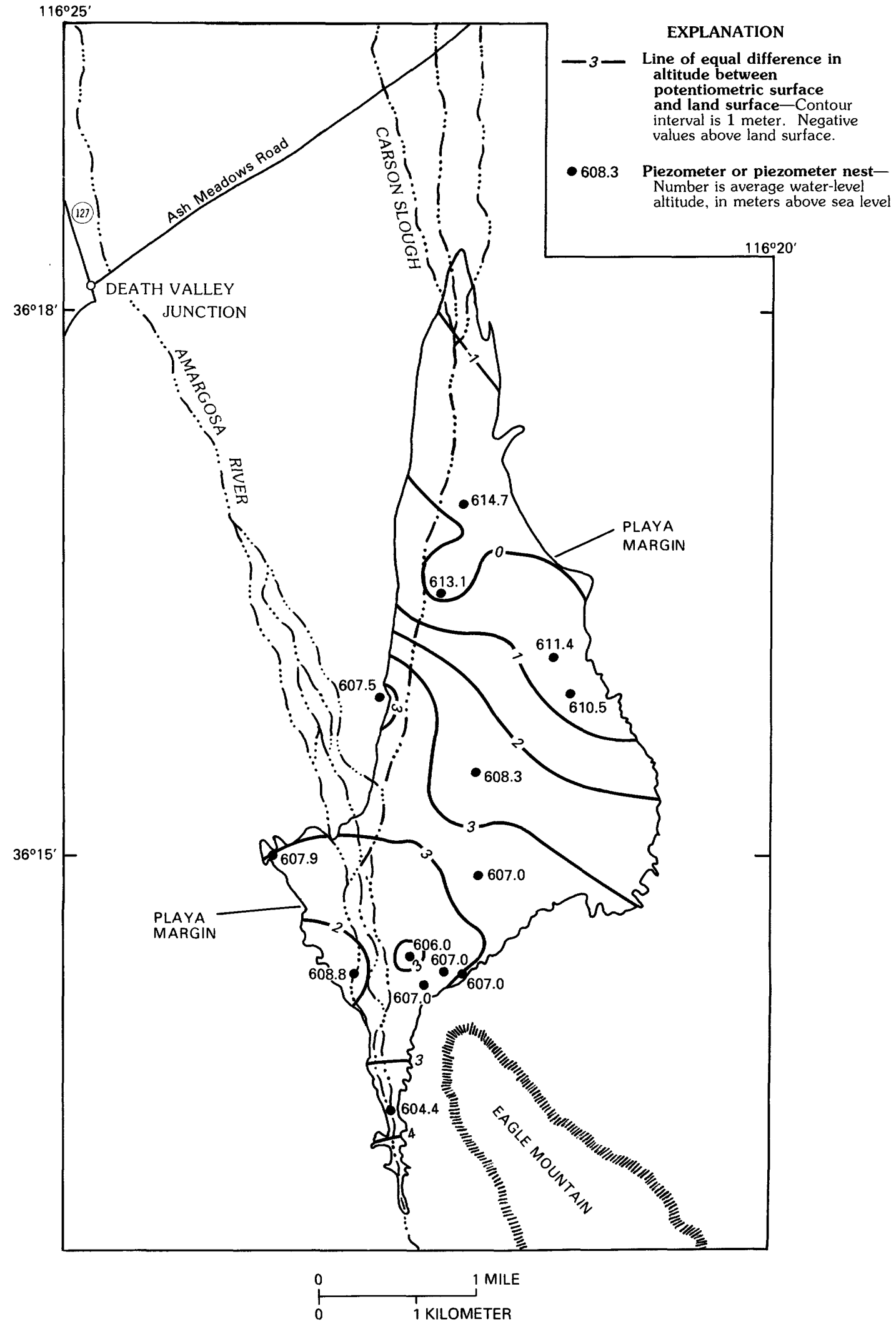

Figure 12. Difference in altitude between potentiometric surface and land surface at Franklin Lake playa. 


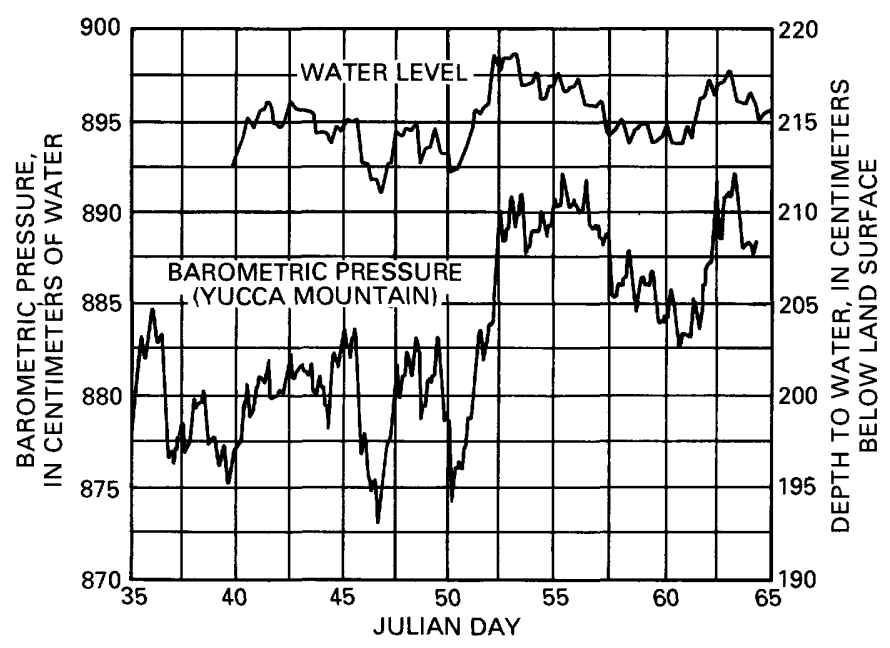

Figure 13. Water levels recorded at wells and barometric pressures recorded at Yucca Mountain from February 4 to March 6, 1985.

In the test of well 14, where the pump was run for 5,400 seconds, the minimum time required for pumping can be calculated by using equation 2 as

$$
\begin{aligned}
t & =\frac{25(0.105 \mathrm{~m})^{2}}{43.5 \mathrm{~m}^{2} / \mathrm{d}} \\
& =0.00633 \mathrm{~d}, \\
& =547 \mathrm{~s},
\end{aligned}
$$

which indicates that pumping was sufficiently long. For the test of well 5, the minimum time is calculated as

$$
\begin{aligned}
t & =\frac{25(0.105 \mathrm{~m})^{2}}{4.6\left(\mathrm{~m}^{2} / \mathrm{d}\right)} \\
& =0.0599 \mathrm{~d} \\
& =5,177 \mathrm{~s},
\end{aligned}
$$

which indicates that pumping duration of 203 seconds was too short. This duration may explain the difficulty in drawing a straight line through the well-5 test data to the origin (fig. 14). Therefore, the transmissivity value estimated from this test is suspect.

Well 5 was pumped to dryness in 203 seconds using a submersible pump at a rate of $85.5 \mathrm{~m}^{3} / \mathrm{d}(1.0$ $\mathrm{L} / \mathrm{s}$ ). Well 14, however, was pumped for 5,400 seconds, and a nearly steady water-level was reached after this time (W.J. Oatfield, U.S. Geological Survey, oral commun., 1985). Recovery of the water table was monitored using an M-Scope electric-tape measuring device. Both wells were cased with 0.21-m-diameter steel casing and slotted over the entire zone of saturation (Jay Mackenzie, Mackenzie Drilling Co., oral commun, 1983). Well 14 probably intersects a more transmissive zone, such as a gravel lens, than does well 5; the vertical or horizontal extent of this zone is unknown.

\section{Falling-Head Injection Tests}

Falling-head injection tests, or "slug" tests, were done on several wells at Franklin Lake playa. These tests were done to estimate values of horizontal hydraulic conductivity in the saturated zone adjacent to the screened interval of each well. Water-level data were collected using a pressure transducer installed in the well, slightly below static water level. For small-diameter $(5.2 \mathrm{~cm}$ or less) wells, water was poured rapidly into the well casing to cause a head rise of about $1 \mathrm{~m}$; for larger diameter casing, a weighted float was used to displace water. Hydraulic-head data from the pressure transducer was recorded as millivolt readings using a Campbell Scientific $21 \mathrm{X}$ micrologger, programmed to record pressure readings when only a specified change in hydraulic head from the previously recorded value was measured. This programming allowed selective storage of essential data.

Results from the slug tests are shown in figures $42 A-F$ in the "Supplemental Data" section at the end of this report. Cooper and others (1967) discussed a technique to determine transmissivity from such a test using type-curve matching. This technique was used for several of the tests, results of which are shown in figures $42 A, C, D, F$, and $G$.

The ratio of $H / H_{o}$ shown in the slug-test figures was calculated from the millivolt-output readings directly after the test had been made. $H_{\mathrm{o}}$ was calculated as the maximum difference between the millivolt readings before and after injection; $H$ was calculated as the difference between the current millivolt reading and the reading prior to injection at any time. Because the conversion from millivolt reading to pressure is linear, no conversion is necessary when calculating $H / H_{o}$ because the ratio is dimensionless. Some tests did not produce results conducive to this analysis; however, relative estimates of transmissivity were made by comparing the times of the first inflection point of the slug-test curves. For example, the first inflection point of the slug-test curve for well GS-17 


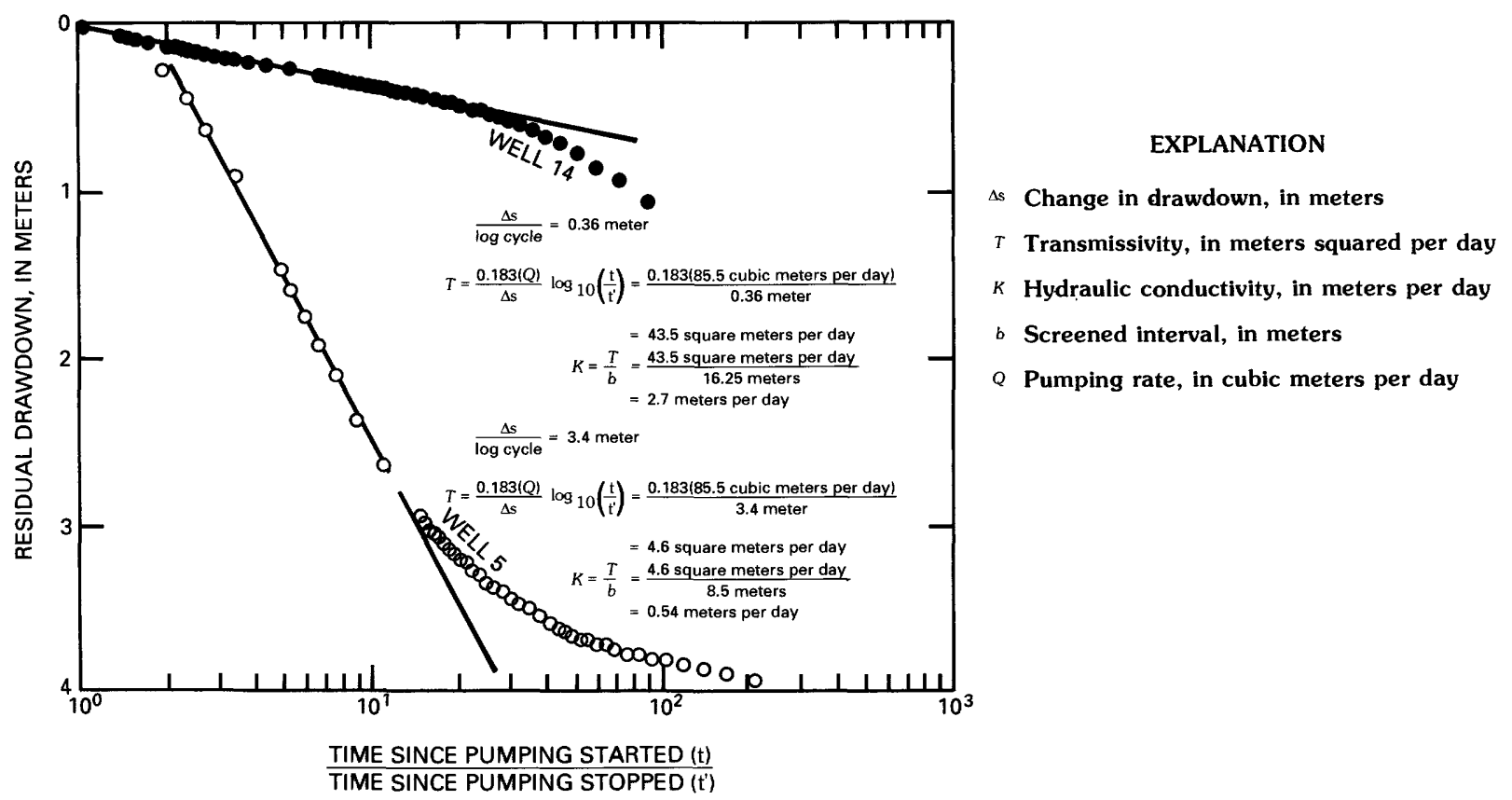

Figure 14. Recovery tests for wells 5 and 14 at Franklin Lake playa.

(fig. $42 \mathrm{H}$ in the "Supplemental Data" section) occurs at about 600 seconds, compared to about $10,000 \mathrm{sec}-$ onds for well 8 (fig. $42 \mathrm{~J}$ in the "Supplemental Data" section), indicating that the transmissivity for GS-17 is larger than that for well 8. Estimates of transmissivity and hydraulic conductivity are summarized in table 2.

Results listed in table 2 indicate that more transmissive sediments may exist to the north and west; these larger values of transmissivity possibly correspond with stream-channel deposits from the meandering stream courses of Carson Slough and the Amargosa River. The relatively large transmissivity estimated for well 14 was determined to be nearly the same for both the slug test $\left(54 \mathrm{~m}^{2} / \mathrm{d}\right)$ and the recovery test $\left(43 \mathrm{~m}^{2} / \mathrm{d}\right)$.

The transmissivity values listed in table 2 indicate a sharp division between values greater than 0.1 $\mathrm{m}^{2} / \mathrm{d}$ and values less than $10^{-3} \mathrm{~m}^{2} / \mathrm{d}$. This discontinuous set of values partly may be related to well construction and point sampling, and it reinforces the concept that playa sediments are spatially heterogeneous. This heterogeneity was observed during the drilling of piezometer holes when fine- to medium-grained sands were penetrated between layers of indurated clays and silts. In addition, mud cracks filled with coarse sand or silt may exist, allowing for preferential flow paths. The distribution of sediment size beneath the playa surface is complex, and it has profound effects on the local transmissivity estimates.

Although heterogeneity is a substantial factor affecting transmissivity estimates, other factors may affect these estimates as well. These factors include as follows: (1) length of the slotted or screened section of well casing, considered as the saturated thickness; (2) presence or absence of clogged slots in the slotted interval; (3) condition of the gravel pack and bentonite seal above the gravel pack around the slotted interval; (4) presence or absence of mud cake on the surface of the well bore; and (5) to a lesser extent, density and viscosity differences in the water resulting from differing hydrochemistries. These factors, particularly (3), in part may explain the difficulties in analyzing the slug-test results for wells GS-22 and GS-18.

\section{Falling-Head Permeameter Tests}

Holes were cored to obtain samples of Franklin Lake playa sediments for hydraulic testing. One objective was to obtain core samples that were representative of the ubiquitous clays penetrated in each augered piezometer hole and to determine the hydraulic conductivity in the vertical direction of the clay material for comparison with field measurements.

Coring was done on June 14 and 15, 1985, at the East study site (EC-2 and EC-3) to obtain saturated core samples that would remain in the core barrel 
Table 2. Summary of slug-test results for several wells at Franklin Lake playa. $[--$, not determined]

\begin{tabular}{|c|c|c|c|}
\hline $\begin{array}{c}\text { Well } \\
\text { number }\end{array}$ & $\begin{array}{l}\text { Transmissivity } \\
\text { (meters squared per day) }\end{array}$ & $\begin{array}{c}\text { Hydraulic } \\
\text { conductivity } \\
\text { (meters per day) }\end{array}$ & Location \\
\hline 14 & 54 & 3.35 & West of playa \\
\hline GS-22 & Between 3.2 and 5.4 & -- & North of playa \\
\hline 7 & 3.2 & 1.2 & South \\
\hline GS-4 & 0.42 & 1.4 & East \\
\hline GS-18 & Between 0.38 and 0.42 & -- & South-central \\
\hline 5 & 0.38 & 0.045 & South \\
\hline 10 & $2.5 \times 10^{-3}$ to $3.4 \times 10^{-2}$ & $2.5 \times 10^{-4}$ to $3.4 \times 10^{-3}$ & South \\
\hline GS-17 & Less than well 10 & -- & Central \\
\hline GS-3 & Less than well GS-17 & -- & East \\
\hline 8 & Less than well GS-3 & -- & South \\
\hline GS-5 & Less than well 8 & -- & East \\
\hline
\end{tabular}

during hydraulic testing. Sections of the recovered core samples were used to estimate the saturated hydraulic conductivity of the playa sediments and the porosity. Some core samples were collected using a hand-driven coring tool. However, this tool failed to recover samples in gravelly sections and failed to recover gravels that had sloughed into the core hole above the next interval to be cored. Sections of 5.27-cm-diameter ABS (acrylonitrile butadiene styrene) plastic pipe were driven past the overlying sloughed-in sections into the underlying clays using a sledge hammer and aluminum block to collect additional core samples. The volume of slough was estimated by measuring the depth of the hole immediately prior to and immediately after the core sample had been taken. If the depth on the next measurement prior to coring had decreased, the difference was assumed to be the result of material that sloughed into the hole. After the ABS pipe containing a section of core was taken out of the hole, the pipe and contents were cut using a hacksaw, were taped on both ends, were marked, and were sealed with wax.

Porosity estimates were made by (1) weighing slices of saturated core samples contained in the plastic pipe, (2) drying the core completely at $110^{\circ} \mathrm{C}$, (3) weighing the dried core, and (4) calculating the weight difference. This weight difference, divided by an assumed fluid density of $1 \mathrm{~g} / \mathrm{cm}^{3}$ and the volume of the pipe holding the core sample, provides an estimate of volumetric water content or porosity. Because the coring tool probably compressed the core sample, the overall porosity measured by this technique probably would produce minimum values, particularly for clays. Values of porosity are listed in table 3.

The saturated hydraulic conductivity of a porous material may be determined in the laboratory using a falling-head permeameter (Bouwer, 1978, p. 40-41), such as the one shown in figure 15 . The equation applicable for determining the hydraulic conductivity $(K)$ when using a falling-head permeameter is

$$
K=\frac{L r^{2}}{t R^{2}} \ln \left(\frac{H_{1}}{H_{2}}\right),
$$

where

$L \quad$ is the length of the sample, in centimeters;

$r$ is the radius of the standpipe, in centimeters;

$H_{1}$ and $H_{2}$ are values of hydraulic head, in centimeters at the beginning and end of a certain time interval, $t$;

$t$ is the time required, in seconds, for the water level in the standpipe to drop from $H_{l}$ to $\mathrm{H}_{2}$; and

$R \quad$ is the radius of the sample, in centimeters.

Core samples obtained in plastic pipe were fitted with end caps (fig. 15B) and used as part of a falling-head permeameter. Water used in the permeameter came from well 5 , which had a hydrochemistry similar to that of the water from the East study-site wells. Values of hydraulic conductivity for four samples are listed in tables 23-26 in the "Supplemental Data" section at the end of this report. Average values from these tests range from $0.07 \times 10^{-8} \mathrm{~cm} / \mathrm{s}$ to $1.22 \times 10^{-8}$ $\mathrm{cm} / \mathrm{s}$. An average of all the values is $0.47 \times 10^{-8} \mathrm{~cm} / \mathrm{s}$. 
Table 3. Porosity determination for core samples from hole EC-2, piece 4.

[All samples were clay; all weights include retaining-cylinder weight; $\rho_{W}$, density of water]

\begin{tabular}{|c|c|c|c|c|c|}
\hline \multirow{3}{*}{ Sample } & \multicolumn{3}{|c|}{ Weight (grams) } & \multirow{3}{*}{$\begin{array}{l}\text { Volume, } \underline{\mathrm{V}} \\
\text { (cubic } \\
\text { centimeters) }\end{array}$} & \multirow{3}{*}{$\begin{array}{l}\text { Porosity } \\
\frac{\left(\underline{w}_{w}-\underline{w}_{d}\right)}{\rho_{w} / \underline{V}}\end{array}$} \\
\hline & Saturated & Dry & Difference & & \\
\hline & $\underline{W}_{W}$ & $\underline{\underline{W}}_{\underline{\mathrm{d}}}$ & $\underline{\underline{W}}_{\underline{w}}-\underline{w}_{\underline{d}}$ & & \\
\hline 1 & 129.23 & 92.08 & 37.15 & 56.0 & 0.66 \\
\hline 2 & 110.75 & 77.60 & 33.15 & 52.3 & .63 \\
\hline 3 & 110.25 & 80.89 & 29.36 & 48.6 & .60 \\
\hline 4 & 91.57 & 66.28 & 25.29 & 40.5 & .62 \\
\hline 5 & 115.97 & 84.84 & 31.13 & 50.4 & .62 \\
\hline 6 & 108.78 & 78.93 & 28.85 & 47.9 & .60 \\
\hline \multirow[t]{2}{*}{7} & 108.80 & 78.65 & 30.15 & 47.9 & .63 \\
\hline & & & & Average porosity: & 0.62 \\
\hline
\end{tabular}

Calculated values of hydraulic conductivity decrease with increased time for a given core sample; however, the reasons for this are not clear. Decreasing hydraulic conductivity during the test may result from (1) swelling of clays within the core sample resulting from using injection water of dissimilar chemistry and removal of ambient over-burden pressure; (2) growth of bacteria in the core causing pores to clog; and (3) translocation of small particles causing pores to clog.

Results from the falling-head permeameter tests are relatively consistent from test to test and give hydraulic-conductivity values that compare favorably with the small values listed in table 2 . The data in table 2 indicate that large heterogeneities may exist, even between closely spaced wells (GS-3 and GS-4). Although the core analyses provide an estimate of the vertical hydraulic conductivity of tight clay, insufficient data exist to dismiss overall larger vertical hydraulic-conductivity values resulting from open fractures or fractures filled with coarser grained sediments. The coring technique used to obtain the core samples probably caused the clay layers to compact as they were forced into the core barrel, resulting in decreased hydraulic conductivity and porosity.

\section{Estimation of Effective Pneumatic Diffusivity and Intrinsic Permeability of the Unsaturated Zone}

By estimating the effective pneumatic diffusivity of the unsaturated zone, an estimate of intrinsic permeability and, therefore, values of hydraulic conductivity can be obtained. To do this, however, the response of the water level in a well to changes in barometric pressure needs to be known.

Changes in barometric pressure at Yucca Mountain and water level in well 5 are shown in figure 13. Inspection of the figure indicates a correlation between peaks and troughs. Weeks (1979) examined this phenomenon with respect to wells completed in deep, unconfined aquifers. He cited the work of several authors (Peck, 1960; van Hylckama, 1968; and Turk, 1975) who have described barometric effects on water levels in wells completed in shallow aquifers at depths to $2 \mathrm{~m}$ below land surface. Weeks (1979) noted that effects reported by these authors were entirely different from those he described concerning deep aquifers, and the mechanism that he described generally would not produce measurable effects in such shallow aquifers. His theoretical description of the mechanism follows:

***Water levels in wells tapping unconfined aquifers are affected by changes in barometric pressure because air must move into or out of the overlying unsaturated zone in order to transmit the pressure change to the water table. This movement is slowed by the finite permeability of the unsaturated materials and by their capacity to store or release soil gas as the pressure changes. Consequently, the change in soil gas pressure at the water table lags that at land surface. However, barometric changes are transmitted essentially instantaneously in a well. This results in a pressure imbalance between the water in the well and water in the adjacent aquifer. The pressure difference produces a water-level fluctuation in the well*** (Weeks, 1979, p. 1167-1168). 


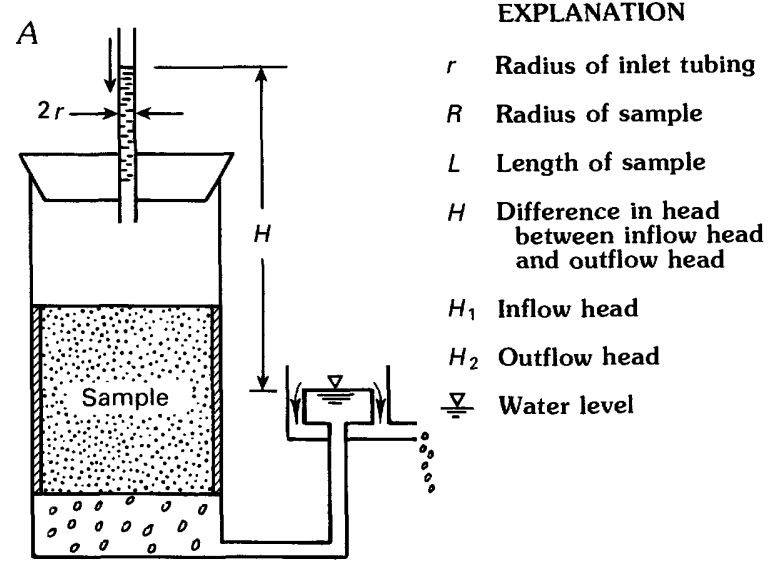

$B$
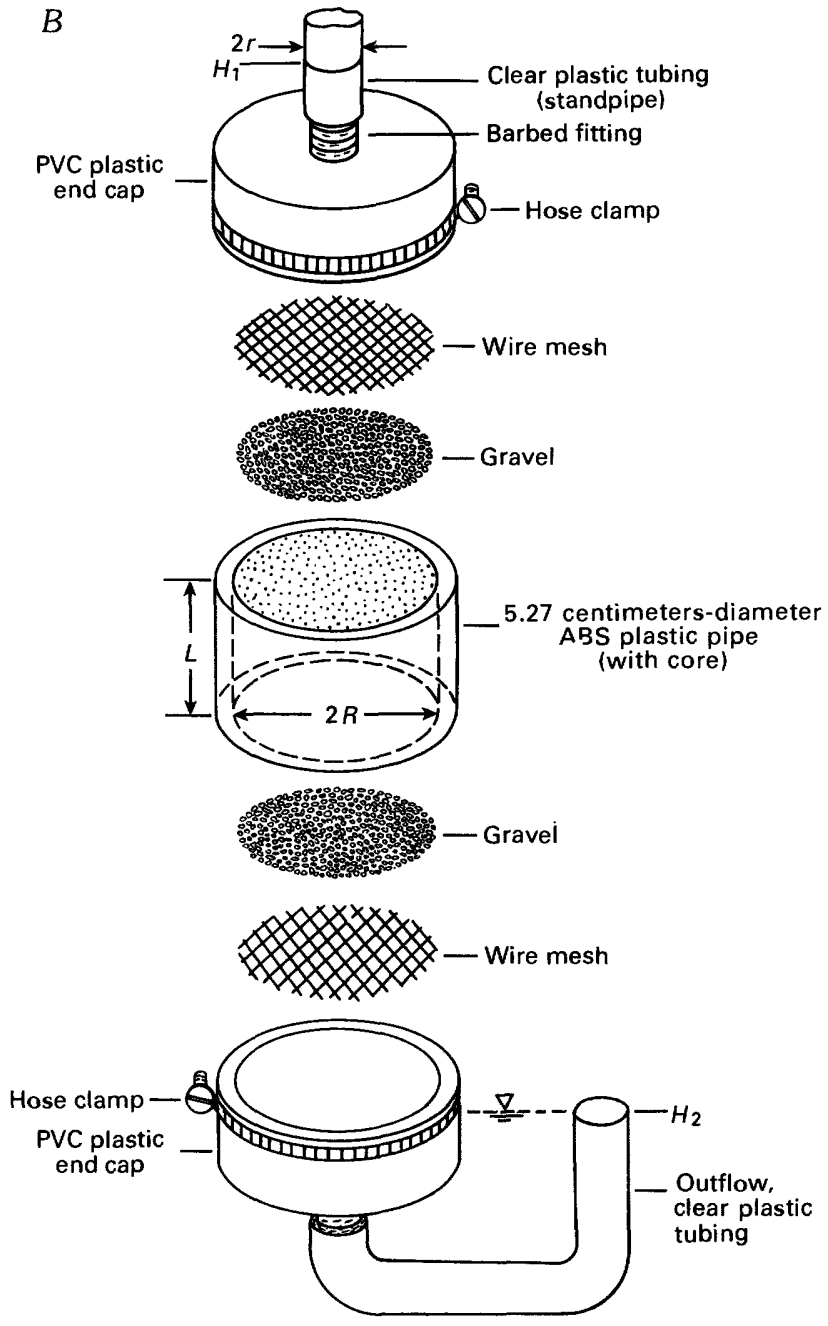

Figure 15. A, View of a falling-head permeameter; and $B$, detailed view of a falling-head permeameter. The falling-head permeameter is used to measure the difference in hydraulic head with time on opposite ends of a cylindrically shaped piece of porous media to calculate its hydraulic conductivity.
Weeks (1979, p. 1170-1172) described a method to estimate the effective pneumatic diffusivity that may be treated as a lumped parameter that includes the properties of the unsaturated materials and the properties of the soil gas. The effective pneumatic diffusivity, $\alpha$, is defined as

$$
\alpha=\frac{k k_{r a} P}{\mu_{a} n_{d}}
$$

where

$k$ is the intrinsic permeability of the porous medium composing the unsaturated zone, $L^{2}$;

$k_{r a}$ is the relative permeability of the medium to air at its prevailing moisture content, dimensionless;

$P$ is the mean pressure during a pressurechange event, $M / L \cdot T^{2}$;

$\mu_{a}$ is the dynamic viscosity of air, $M / L \cdot T$; and

$n_{d}$ is the air-filled porosity, dimensionless. Units used in this equation are specific to the situation of application.

The effective pneumatic diffusivity was estimated using the step-change method (Weeks, 1979, p. 1170-1172) that predicts the barometric effect on the water level in the well based on step changes in barometric pressure. A short computer program was used to estimate the change in water level by step changes in barometric pressure and to estimate the optimum fit with measured changes.

The change in water level $\left(\Delta W L_{j}\right)$ was estimated using the relation of Weeks (1979, p. 1171):

$$
\begin{aligned}
& \Delta W L_{j}=\sum_{i=1}^{j} \frac{4 H_{i}}{\pi} \sum_{m=1,3,5 \ldots}^{\infty}(-1)^{(m-1) / 2} \frac{1}{m} \\
& \exp \left[-m^{2} \pi^{2} \alpha \Delta t\left(j-i+\frac{1}{2}\right) / 4 l^{2}\right],
\end{aligned}
$$

where
$\Delta W L j \quad$ is the change in water level, in $\mathrm{m}$;
$H_{i}$ is the magnitude of step-change barometric pressure during the $i$ th time step, in m;

$\Delta t \quad$ is the incremental time step, 1 hour; and $l \quad$ is the thickness of the unsaturated zone, in $\mathrm{m}$.

The thickness of the unsaturated zone, 1, was specified to be $2 \mathrm{~m}$ at well 5 . 
The optimum fit was calculated as a root-mean-square error (RMSE), or:

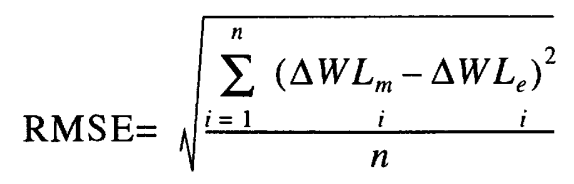

where

$n$ is the number of hourly measurements, dimensionless;

$\Delta W L_{m}$ is the measured change in water level, in m; and

$\Delta W L_{e}$ is the estimated or predicted change in water level, in $\mathrm{m}$.

The change in RMSE for different values of $\alpha$ is shown in figure 16; the best fit, or minimum value of RMSE, was achieved using a value of $0.06 \mathrm{~m}^{2} / \mathrm{h}$ for $\alpha$. The predicted and measured changes in water levels for well 5 are shown in figure 17; predicted changes are based on a value of $\alpha$ equal to $0.06 \mathrm{~m}^{2} / \mathrm{h}$.

The intrinsic permeability of the porous medium that composes the unsaturated zone, $k$, may be estimated using equation 4 , if all other variables in the equation are known. The air-filled porosity, $n_{d}$, was estimated to be 0.2 , based on soil-moisture profiles and porosity measurements. The dynamic viscosity of air was estimated to be $2 \times 10^{-4}(\mathrm{~g} / \mathrm{cm}) / \mathrm{s}$; the relative permeability of the medium to air was estimated to be 0.1 , based on figure 2-51 in Katz and others (1959, p. 64). The mean atmospheric pressure was estimated to be $1 \times 10^{6} \mathrm{dynes} / \mathrm{cm}^{2}$. Using these values and a value

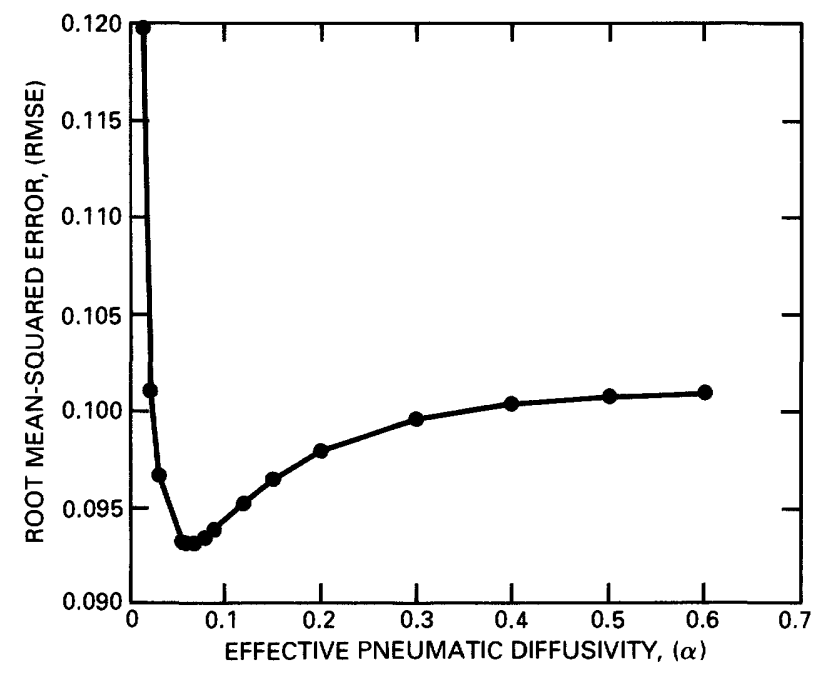

Figure 16. Relation of root-mean-squared error (RMSE) to various trial values of effective pneumatic diffusivity $(\alpha)$. of $\alpha$ equal to $0.06 \mathrm{~m}^{2} / \mathrm{h}$, the intrinsic permeability of the unsaturated zone, $k$, was calculated to be $6.6 \times$ $10^{-15} \mathrm{~m}^{2}$; it corresponds to a saturated hydraulic conductivity of $6.5 \times 10^{-6} \mathrm{~cm} / \mathrm{s}$, or $0.006 \mathrm{~m} / \mathrm{d}$.

Although the predicted and measured changes in water level in well 5 , shown in figure 17 , represent an acceptable match along certain parts of the graph, the fit was not perfect. The differences probably are related to any of the following factors: (1) Airtemperature effect; (2) the Klinkenberg effect; and (3) errors in water-level and air-pressure measurement.

\section{Air-Temperature Effect}

The effects of air temperature on measured water levels have been documented previously (Gatewood and others, 1950). During tank studies designed to measure changes in water level in lysimeters containing soil, water, and phreatophytes, Gatewood and others (1950, p. 112-114) recorded water-level rises resulting from the sudden heating of the soil from placement of hot rocks on the soil surface. Although the temperature at land surface at Franklin Lake playa varies up to $25^{\circ} \mathrm{C}$ in any given day, the effect on the water level in a well cannot readily be determined because atmospheric pressure also responds to changes in air temperature. Because of this coupled response and the difficulty in separating individual components, no correction for the air-temperature effect was made.

\section{The Klinkenberg Effect}

The Klinkenberg effect (Klinkenberg, 1941, p. 200 ) occurs during gas flow through a capillary or porous medium when, at low pressures, the length of the mean free path of the gas molecules approaches the diameter of the capillary tube or pore (Weeks, 1979, p. 1170). Under these conditions, the Hagan-Poiseuille velocity distribution no longer holds because some gas molecules tend to slip along the capillary walls. Thus, for very fine grained materials, such as those beneath Franklin Lake playa, the intrinsic permeability, as measured by gas flow, exceeds that measured by liquid flow. 


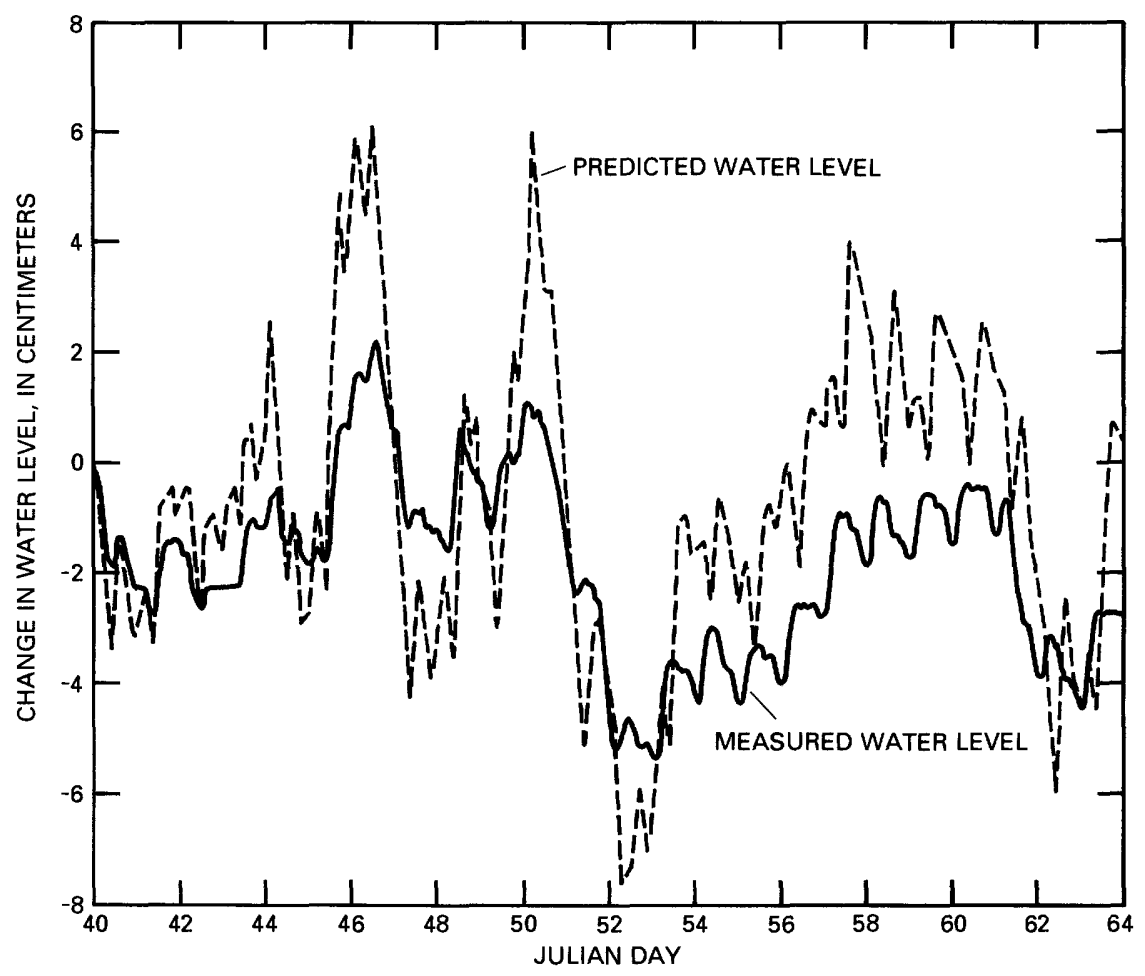

Figure 17. Predicted and measured changes in water levels in well 5 resulting from changes in atmospheric pressure at Franklin Lake playa.

Katz and others (1959, p. 44-45) gave a relation to estimate air permeability $\left(K_{a}\right)$, based on liquid permeability $\left(K_{l}\right)$, as

$$
K_{a}=K_{l}\left(1+\frac{b}{P_{m}}\right)
$$

where

$b$ is a factor that is a function of liquid permeability, in atmospheres, $K_{l}$;

and

$P_{m}$ is the atmospheric pressure, in atmospheres.

When an atmospheric pressure of 1 atmosphere is assumed, a value of $b$ equal to 0.4 (obtained from figure 2-17 of Katz and others, 1959, p. 45), and a value of $6.6 \times 10^{-15} \mathrm{~m}^{2}$ for $K_{l}$, the air permeability, $K_{a}$, is 40 percent greater than the liquid permeability.

\section{Errors in Measurement}

The effects of errors that result in improper measurement are directly related to obtaining a suitable match between predicted and measured changes in water level. One assumption made in using equation 5 was that the barometric data from Yucca
Mountain were appropriate for use at Franklin Lake playa. The two locations are about $60 \mathrm{~km}$ apart, and they differ by about $600 \mathrm{~m}$ in altitude. Most of the major atmospheric-pressure changes result from regional storm systems. Some of the lag or offset shown in figures 13 and 17 may result from the distance between these two locations. Errors in measurement probably are less than the uncertainty in estimates of air-filled porosity (which is directly proportional to intrinsic permeability) and relative permeability of the medium to air (which is inversely proportional to intrinsic permeability) used to estimate intrinsic permeability of the unsaturated zone (eq. 4).

\section{Summary of Transmissivity and Hydraulic-Con- ductivity Estimates}

A summary of values of transmissivity and hydraulic conductivity for all the techniques used is listed in table 4. The first two techniques listed (pumped-well recovery tests and falling-head injection tests) were designed to estimate horizontal components of hydraulic conductivity; the latter two techniques (falling-head permeameter tests and determination of effective pneumatic diffusivity) were designed to estimate vertical hydraulic conductivity. 
Table 4. Summary of transmissivity and hydraulic-conductivity values obtained from all techniques.

$[--$ indeterminable $]$

\begin{tabular}{|c|c|c|}
\hline Technique & $\begin{array}{l}\text { Transmissivity } \\
\text { meters squared per day) }\end{array}$ & $\begin{array}{l}\text { Hydraulic conductivity } \\
\text { (meters per day) }\end{array}$ \\
\hline $\begin{array}{l}\text { Pumped-well recovery tests } \\
\text { Falling-head injection tests } \\
\text { Falling-head permeameter tests } \\
\text { Determination of effective } \\
\text { pneumatic diffusivity }\end{array}$ & $\begin{aligned} 4.6 \text { to } 43.5 \\
<\times 10^{-8} \text { to } 54 \\
\ldots-\end{aligned}$ & $\begin{array}{l}<4 \times 10^{-54} \text { to } 2.7 \\
6 \times 10^{-7} \text { to } 3.4 \\
\\
6 \times 10^{-3}\end{array}$ \\
\hline
\end{tabular}

The first two techniques gave a wide range of estimates of horizontal hydraulic conductivity for well and piezometer sites located throughout most of the playa. The latter two techniques were used to estimate hydraulic conductivity at only two locations on the playa (East and South sites), but because these estimates are of the vertical component of hydraulic conductivity, they are more appropriate for estimating vertical flow than are the horizontal estimates. In addition, the results obtained using the falling-head permeameter tests on core samples probably underestimate the ambient, vertical hydraulic conductivity because of (1) swelling of clays within core samples, (2) pore clogging that results from growth of bacteria in the core sample and translocation of small particles, and (3) compaction of the core sample during the coring procedure. Consequently, the estimate of vertical hydraulic conductivity of $0.006 \mathrm{~m} / \mathrm{d}$ obtained by determining the effective pneumatic diffusivity probably is the better estimate because it is based on onsite measurements.

\section{ESTIMATION OF EVAPOTRANSPIRATION}

Several methods were used to directly or indirectly estimate evapotranspiration at Franklin Lake playa: (1) estimation of local evapotranspiration by direct measurement of the local energy budget using the eddy-correlation technique; (2) indirect estimation of potential evapotranspiration (PET) using empirical relations for meteorological data from distant, but similar, locations; (3) indirect estimation of evapotranspiration using the difference in moisture contents derived from neutron logs in the unsaturated zone over time; (4) indirect estimation of evapotranspiration based on mapping location and distribution of phreatophytes in and around the playa; (5) indirect estimation of evapotranspiration using temperature logs to estimate vertical ground-water velocity; (6) estimation of evapotranspiration by measuring vertical ground-water flow in the saturated zone; and (7) indirect estimation of evapotranspiration using a one-dimensional finite-difference model of flow from the water table to land surface. All but (3) and (5) give usable estimates of evapotranspiration. Each of these methods is described in detail in the following sections. This application of multiple, independent methods provides an opportunity to check and compare evapotranspiration estimates.

\section{Energy-Balance Eddy-Correlation Technique}

\section{By David I. Stannard}

To characterize the evapotranspiration rate in the study area on an annual basis, periodic micrometeorological measurements were made using eddy-correlation equipment based on the energy-balance eddy-correlation technique (EBEC). Latent heat flux (the energy flux used in evaporating water from a surface) was estimated as the residual to an energy-balance equation. Measurements were made during periods of 1 to 3 days in June and October 1983, and in January, April, and September 1984. In June 1983, measurements were made at only two sites on the playa because of limited equipment. More sites were added on successive measurement periods; the two original sites were retained throughout the program.

\section{Theory}

Energy-balance techniques for estimation of evapotranspiration have received increasing use since their inception about the beginning of this century (Brutsaert, 1982). If advection can be neglected (Campbell, 1977, p. 40), and the change in energy 
stored in the plant canopy and the upper $2 \mathrm{~cm}$ of soil is negligible (Fritschen, 1965), the energy-flux densities associated with a vegetated surface are related by an energy-balance equation (Campbell, 1977, p. 136):

$$
R_{n}-G-H-\lambda E=0
$$

where

$R_{n}$ is the net-radiation-flux density for the surface, in watts per square meter;

$G$ is the heat-flux density into the soil, in watts per square meter;

$H$ is the sensible-heat-flux density into the air above the plant canopy, in watts per square meter;

$\lambda$ is the latent heat of vaporization of water, in joules per gram; and

$E$ is the rate of evapotranspiration, in grams per second per square meter.

The sensors used to evaluate $R_{n}$ and $H$ in equation 8 need to be located above the plant canopy if the land surface is vegetated. The sensors used to measure $G$ in equation 8 need to be located just below the soil surface. The distance from the sensors to the upwind edge of the vegetation type being studied is known as the fetch. Generally, advection is negligible if the fetch is at least 100 times the instrument height (Campbell, 1977, p. 40). The term "vegetative type" implies that no obvious large-scale inhomogeneities in soil or vegetation occur within the fetch.

When the energy-balance method is used, a horizontal layer (fig. 18) is established that has an upper boundary just above the plant canopy (at the height of the sensors used to measure $R_{n}$ and $H$ ) and a lower boundary just below the soil surface (at the depth of the sensors used to measure $G$ ). The layer extends horizontally to the boundaries of the vegetation type. The change in energy storage in the plant canopy and in the soil within the layer is negligible if energy-flux measurements are integrated over a 24-hour period (Fritschen, 1965). Therefore the 24-hour integrals of $R_{n}, G, H$, and $\lambda E$ that enter or leave the layer are virtually equal to the 24-hour integrals of $R_{n}, G, H$, and $\lambda E$ that enter or leave the vegetated surface. In this study, the energy-flux densities, $R_{n}, G$, and $H$, that enter or leave the layer are measured, and $\lambda E$ is estimated by solving equation 8 . For brevity, flux densities are hereinafter referred to simply as fluxes.
Net-radiation, $R_{n}$, is the energy source "driving" the other fluxes; it is equal to the solar and atmospheric radiation entering the layer less the surface thermal radiation and the reflected solar radiation leaving the layer. Incoming short-wave (visible) radiation less reflected shortwave radiation always is directed downward; whereas, outgoing longwave (thermal) radiation less incoming atmospheric thermal radiation usually is directed upward. Because the daytime shortwave magnitude is larger than longwave, daytime net radiation is directed downward; conversely, nighttime net radiation usually is directed upward. The 24-hour integral is a large flux, directed downward.

Soil-heat flux, $G$, is the heat that flows by conduction and by latent heat transport through the lower boundary of the layer. Usually, soil-heat flux is directed downward during the day and upward during the night, producing a 24-hour integral that is often near zero. As the soil surface is warmed through the day, some of that energy is convected into the air above, establishing an air-temperature profile characterized by decreasing temperature with altitude.

Heat flux across the upper boundary of the layer resulting from this temperature gradient is the sensible-heat flux $(H)$. Over most terrestrial surfaces, sensible-heat flux is directed upward during the day and downward during the night; over a period of 1 day, the integral of sensible-heat flux is directed upward. However, over a dry surface with a large specific-heat capacity (such as dry sand or rock), sensible-heat flux may be directed upward continuously during warm months. Conversely, a very lush, well-watered crop (such as alfalfa) often remains cooler than the overlying air through the day, maintaining a downward flow of sensible heat, known as an inversion.

The evaporation of water from the plant and soil surfaces into the atmosphere requires energy, known as the latent heat of vaporization of water, $\lambda$; it is equal to 2,450 joules per gram of water at $20^{\circ} \mathrm{C}$, and it varies slightly as temperature changes. Evapotranspiration, then, can be thought of as an energy flux directed upward, equal to $\lambda$ times the mass flow rate of water. Most evapotranspiration occurs during daylight hours. If air temperature drops below the dewpoint during early morning hours, a downward-directed vapor flux occurs, resulting in dew.

The four energy fluxes, which are assumed to be distributed evenly over a given vegetation type, are 


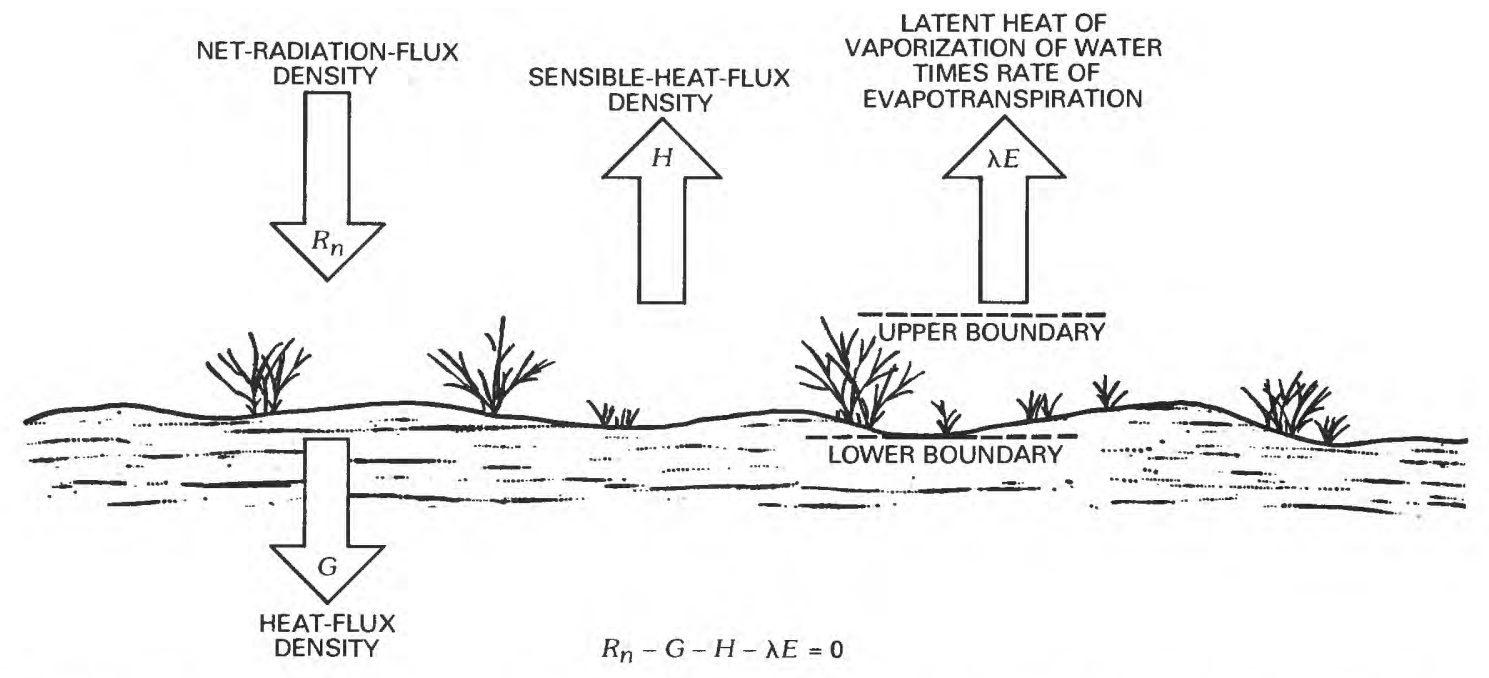

Figure 18. The energy-balance method for estimating evapotranspiration. Net radiation, $R_{n}$, supplies energy to the vegetated surface. The energy is lost to the surroundings through $G$, the soil-heat flux, by conduction and by latent heat transport of soil water; through $H$, the sensible-heat flux, by convection to the overlying air; and through $\lambda E$, the latent-heat flux, on energy flux equal to the latent heat of vaporization of water $(\lambda)$ times $E$, the evapotranspiration rate of water from the leaf and soil surfaces to the overlying air.

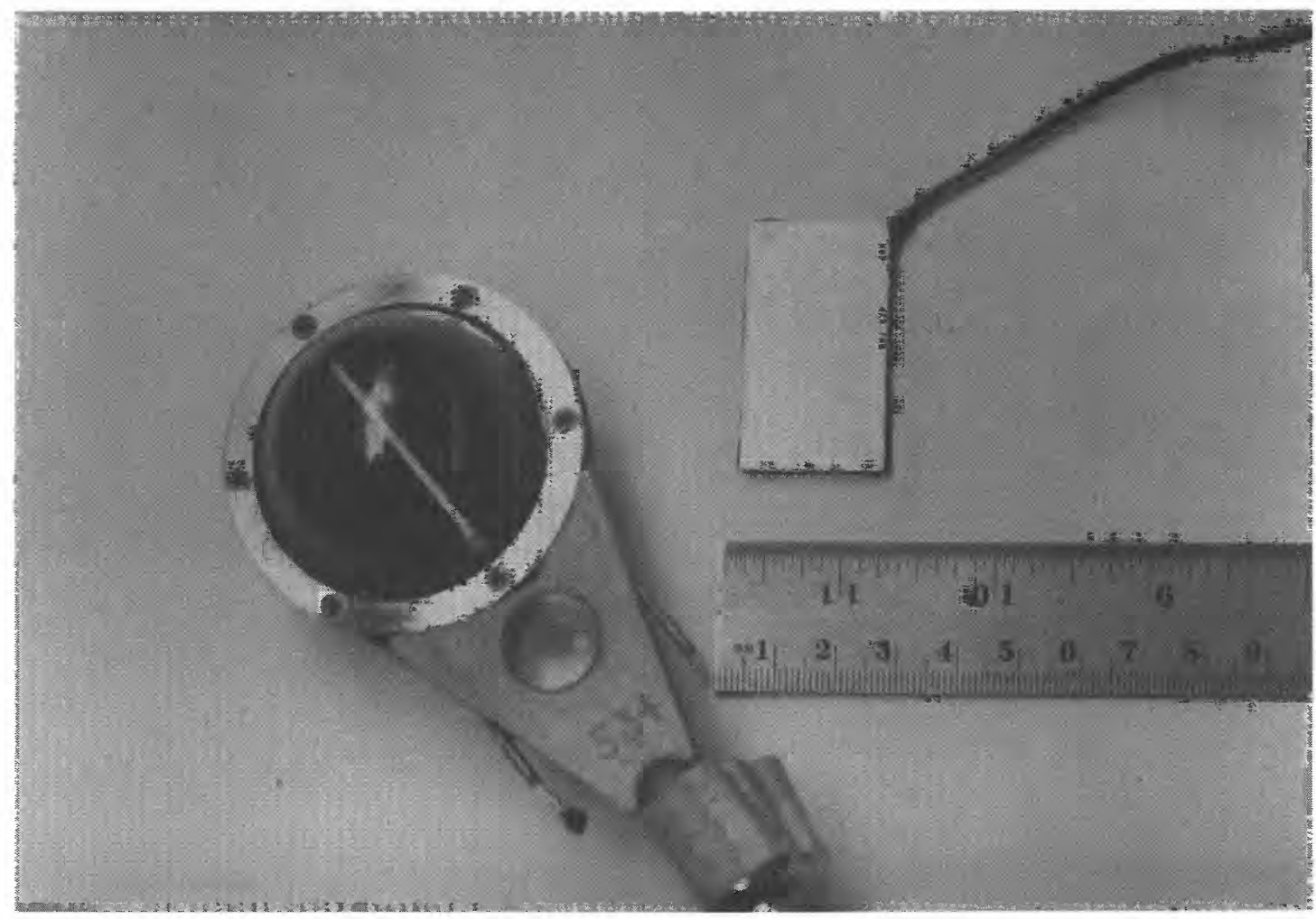

Figure 19. Net radiometer and soil-heat-flux plate. Net radiometer (below, in photo) uses a thermopile to measure temperature difference between upper blackened surface (visible beneath polystyrene window) and lower blackened surface (not visible). Soil-heat-flux plate (above, in photo) uses a copper-constantan thermopile to measure temperature difference between upper surface (visible) and lower surface (not visible). Both sensors output a voltage proportional to flux. Scale in photo has inches on left side and centimeters on right side. 
expressed as energy-flux densities per unit time.The units used in this report are $\mathrm{Wm}^{-2}$ (watts per square meter).

\section{Equipment}

Net-radiation and soil-heat flux were measured at Franklin Lake playa with two types of thermopile devices. For net radiation, Fritschen-type net radiometers (Fritschen, 1965) were used; these radiometers have a nominal sensitivity of about $4.5 \mu \mathrm{Vm}^{2} \mathrm{~W}^{-1}$ and are nonventilated two-sided, blackened thermal transducers with polystyrene radiation windows (fig. 19). The temperature difference between the upper and lower surfaces is converted to a voltage signal by a thermopile. These radiometers were positioned level at the upper boundary of the layer, about $1.5 \mathrm{~m}$ above land surface.

Two types of soil-heat-flux plates were buried at various depths below land surface. The first type of plate uses a copper-constantan thermopile to convert the temperature difference between the upper and lower surfaces of the plate into a voltage signal (Tanner, 1963); the second type uses a thermopile made of semiconductor materials to do the same thing (Weaver and Campbell, 1985). The sensitivity of the first type ranges between 5 and $10 \mu \mathrm{Vm}^{2} \mathrm{~W}^{-1}$, and the thermal conductivity is $1.0 \mathrm{Wm}^{-1}{ }^{\circ} \mathrm{C}^{-1}$, corresponding to that of a dry sand (Weaver and Campbell, 1985). The sensitivity of the second type ranges between 70 and 80 $\mu \mathrm{Vm}^{2} \mathrm{~W}^{-1}$, and the thermal conductivity is $0.4 \mathrm{Wm}^{-1}$ ${ }^{\circ} \mathrm{C}^{-1}$ (Weaver and Campbell, 1985).

If the thermal conductivity of the heat-flux plate is different from the surrounding soil, an error in measured heat flux will occur (Philip, 1961) because of a thermal disturbance caused by the plate. No data were collected to estimate the thermal conductivity of the soil surrounding the heat-flux plates of Franklin Lake playa; therefore, no correction to the measured soil-heat flux was made.

In June and October 1983, the plates were buried $5 \mathrm{~cm}$ below land surface; thereafter, they were buried at 1- or 2-cm depths. Simultaneous placement of plates at all three depths showed very little change in the 24-hour integrals of soil-heat-flux density with depth, even though the playa sediments often were moist at a depth of $5 \mathrm{~cm}$. Resulting differences in estimation of $\lambda E$ were considered insignificant.
Sensible-heat-flux density, $\mathrm{H}$, was measured with a CA 27-T sonic anemometer made by Campbell Scientific in Logan, Utah (fig. 20). The anemometer uses the phase shift between upwardand downward-directed high-frequency sound waves to measure vertical windspeed. In addition, it is equipped with a $12.7-\mu \mathrm{m}$-diameter, fine-wire thermocouple to measure the air-temperature fluctuations at the same location. A Campbell CR-5 data logger with special firmware (fig. 21) was used to integrate the vertical windspeed and air-temperature fluctuations at an effective frequency of 3-4 hertz (Weeks and others, 1987) to produce 5-minute means and covariances. The sensible-heat flux was calculated from the covariance of vertical windspeed with air temperature as

where

$$
H=\bar{\rho}_{\alpha} C_{p} \overline{w^{\prime} T^{\prime}},
$$

$H$ is sensible-heat flux, in watts per square meter

$\bar{\rho}_{a}$ is mean air density, in grams per cubic meter;

$C_{p}$ is specific heat capacity of air, in joules per gram per degree Celsius; and

$\overline{w^{\prime} T}$ is the covariance of vertical windspeed $(w)$ with air temperature, $(T)$ in meter-degree Celsius per second.

The sound path of the sonic anemometer was aligned vertically at the upper boundary of the layer, about $1.5 \mathrm{~m}$ above land surface. Copper-constantan thermocouples were positioned about $1 \mathrm{~m}$ above land surface, shaded from direct sunlight, to measure air temperature. Air temperature was used to determine the value of $\bar{\rho}_{a}$ equation 9. The value of $C_{p}$ in equation 9 was assumed to be $1.01 \mathrm{~J} \mathrm{~g}^{-1{ }^{\circ}} \mathrm{C}^{-1}$.

\section{Measurement Sites}

Most of the surface of Franklin Lake playa is not vegetated, and about one-half of the nonvegetated surface is a white to off-white salt crust; the other half is a fragile, porous, silty-sand surface, ranging in color from tan to brown. The Amargosa River channel enters the playa from the northwest, and Carson Slough enters the playa from the north (fig. 4); these channels braid out, and the more prominent channels are located in the western one-third of the playa. Although the surface usually is dry, the sediments just 


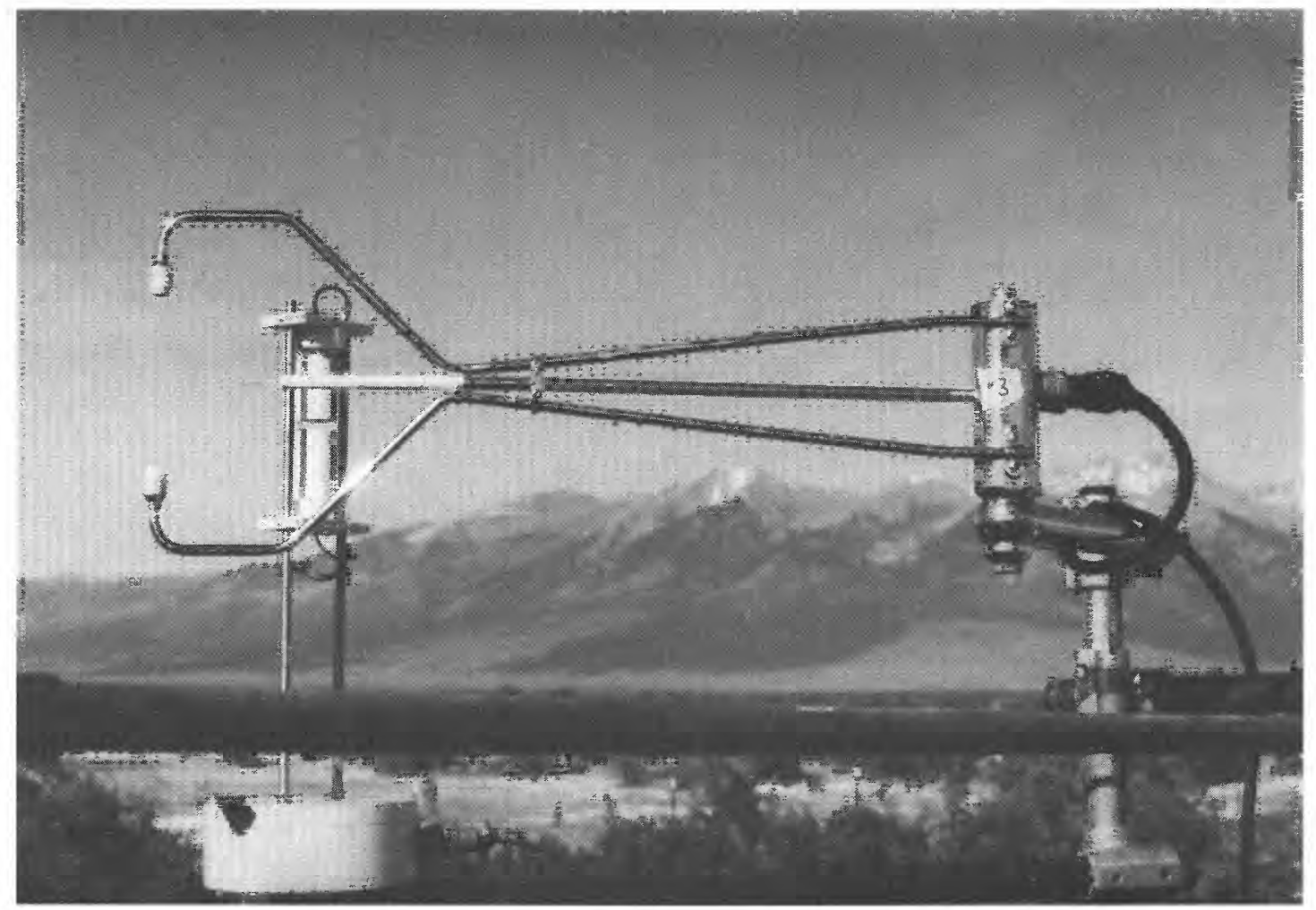

Figure 20. Sonic anemometer. (The sensor in the background is a krypton hygrometer, but was not used in this study.) The upper and lower white-colored transponders emit and receive high frequency sound waves. A measurement of the phase shift of the received frequency is proportional to the vertical windspeed between the two transponders. A fine-wire thermocouple (too small to see) that rapidly measures air temperature fluctuations is supported midway between the transponders by the white rod to the right of the transponders.

below the surface remain mucky, especially in the broad expanses that are void of braiding.

Vegetation primarily consists of the phreatophytes seep weed (Suaeda fruticosa, Munz, 1974, p. 370) and greasewood (Sarcobatus vermiculatus, Jaeger, 1940, p. 45), although small quantities of saltgrass (Distichlis stricta, Beatley, 1976, p. 283) occur, mainly concentrated near the few springs and seeps at the northern and eastern playa margins. The white, salt crust apparently prevents the establishment of seedlings, restricting vegetation to the lower salt content, darker colored areas, mainly along the braided river channel.

Eddy-correlation sites (fig. 22) were selected to (1) optimally cover as much of the playa surface with as few measurement sites as possible, (2) represent the different land-surface types, and (3) be accessible by four-wheel drive vehicles. The last requirement prevented using much of the southeast quadrant, because it usually was mucky just below land surface.

The North site is located in a sparse but extensive greasewood and seep weed community (fig.
23) that has an average plant separation of $10 \mathrm{~m}$. The shortest fetch is $0.7 \mathrm{~km}$ from the south, the average plant height is about $0.6 \mathrm{~m}$, and maximum plant height is about $1.0 \mathrm{~m}$.

The South-Central site (fig. 24) is unvegetated, has a light-reddish-brown soil, and is located near the southern end of the playa. Adequate fetch occurs in all directions except to the east, where a single 4-m-wide, white river channel runs north and south about $100 \mathrm{~m}$ from the site. The channel was considered to be small enough and far enough away that it had an insignificant effect on the measured sensible-heat flux.

The South-West site was included primarily to represent the western extent of the playa. The site is located near the northwestern corner of a whitish, sparsely vegetated lobe of the playa, about $0.7 \mathrm{~km}^{2}$ in area. Seep weed and greasewood grow at this site and have an average plant separation of $15 \mathrm{~m}$. If the wind is from the west, the fetch is inadequate, and sensible heat advected from the hot, dry area west of the playa would produce erroneously low estimates of 


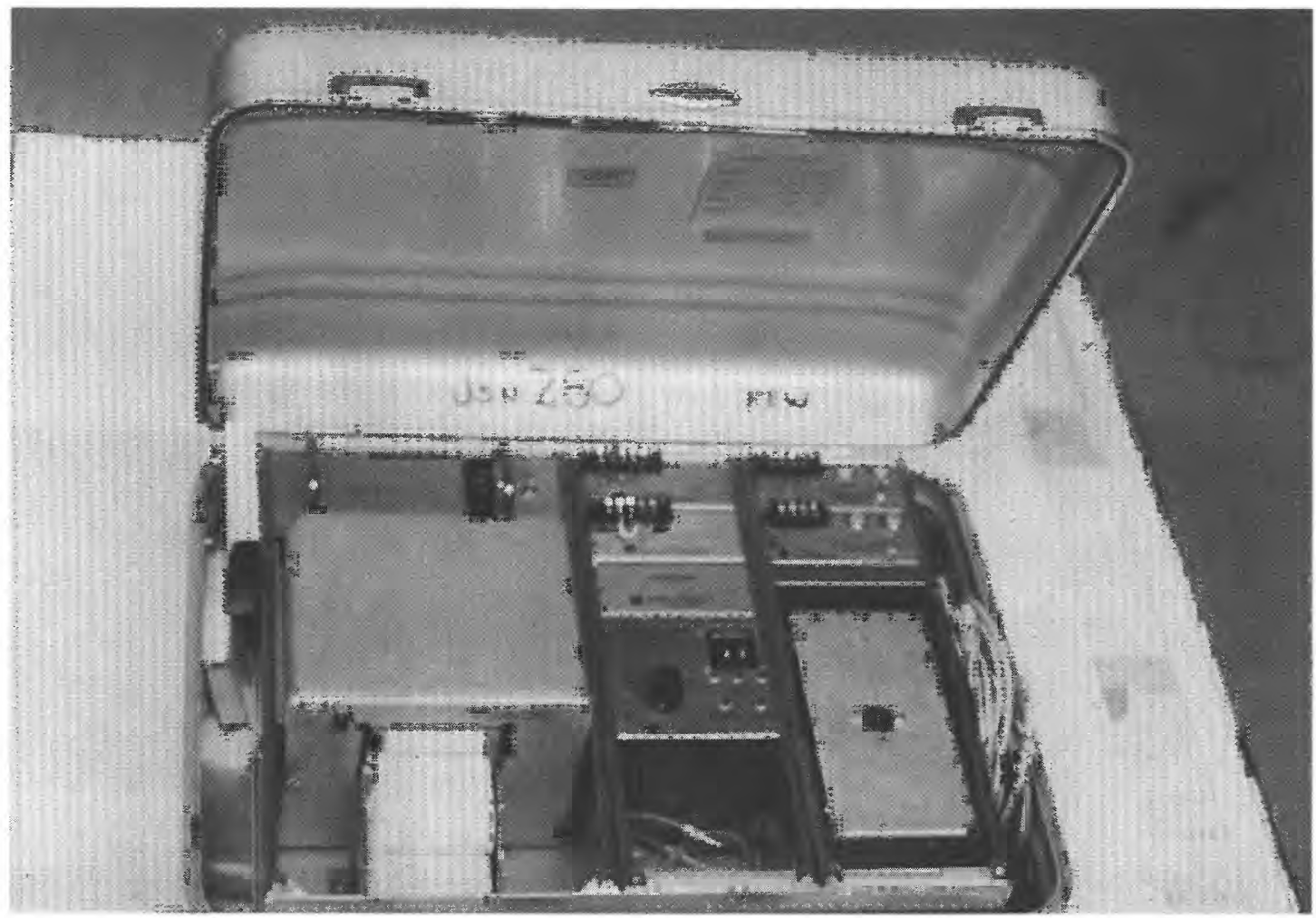

Figure 21. Solid-state datalogger. Wires from sensors are connected to terminals at right-rear of logger. Date and time are set with thumb wheel (center), and data are recorded on paper tape (left-front) and on magnetic cassette tape (not shown). Latching case is weatherproof.

evapotranspiration. However, the soft playa surface prevented the selection of a new site at a location more representative of the lobe.

The East site, located near the eastern edge of the playa, was selected to represent the shallower water-table conditions that occur there. The site is not vegetated (although saltgrass is abundant a few hundred meters to the north), and it has adequate fetch in all directions.

The Obelisk and Salt sites are not on the playa but are near its extreme northern end. The Obelisk site was selected to represent dense vegetation. Greasewood and seep weed grow extensively and have an average plant separation of $3 \mathrm{~m}$. Average plant height is $1 \mathrm{~m}$; maximum plant height is $1.4 \mathrm{~m}$. Adequate fetch occurs in all directions. The Salt site is located near the eastern edge of a very white, uniform, triangular salt flat, about $4.6 \mathrm{~km}$ north of the North site. The Salt site was selected because the brilliance and thickness of the salt crust indicated the possibility of steady upward movement of water. A mucky subsurface prevented the instruments from being located near the center of this surface, which resulted in an inadequate fetch when winds were from the east.

The Central site is similar to the South-Central site in land-surface type except that it is a little lighter in color. Adequate fetch occurs in all directions at the Central site.

\section{Measurements}

The covariance of vertical windspeed with air temperature, $\overline{\mathrm{w}^{\prime} \mathrm{T}^{\prime}}$, was calculated every 5 minutes by the CR-5 datalogger, and six 5-minute covariances were accumulated to produce 30 -minute averages. The net-radiometer, soil-heat-flux plate, and thermocouple signals continuously were integrated to produce 30-minute averages. The 30-minute averages, reported at the end of each one-half hour, were recorded on magnetic cassette tapes and printed on paper tape. Average fluxes subsequently were calculated for an integral number of days, to minimize the 


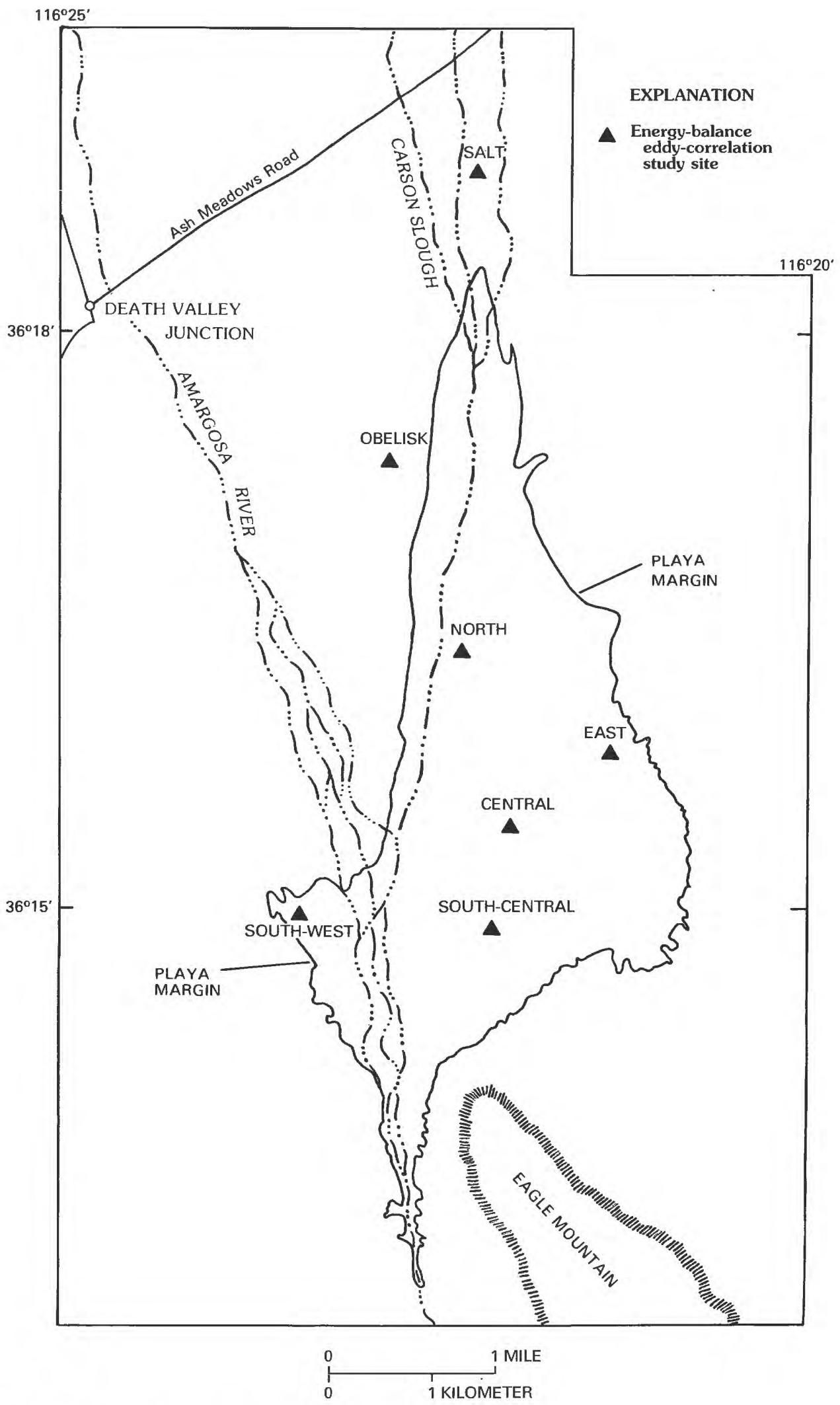

Figure 22. Location of eddy-correlation sites. 


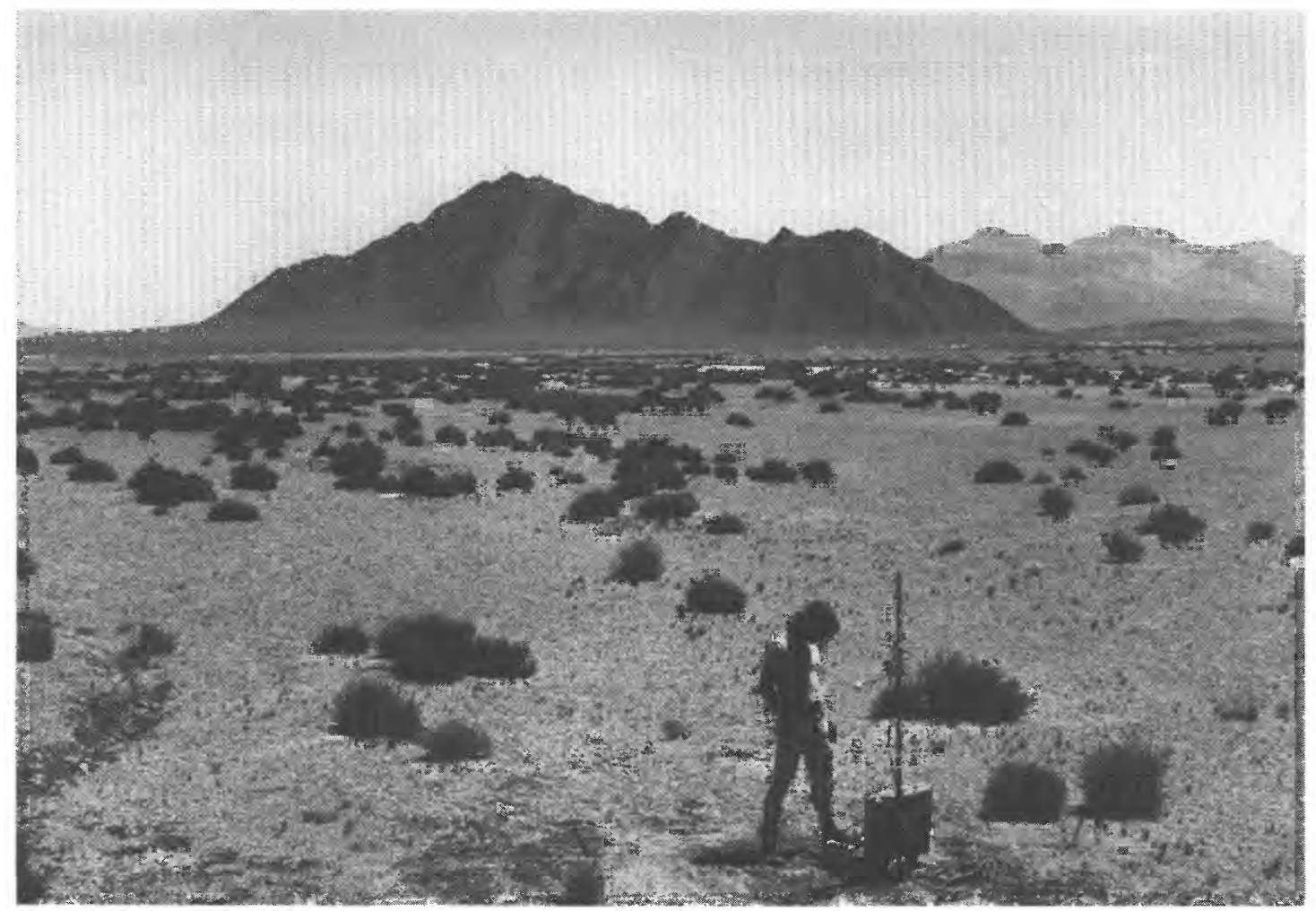

Figure 23. The North site during energy-balance eddy-correlation measurements of evapotranspiration. Vegetation is primarily greasewood (Sarcobatus vericulitus) and seep weed (Suaeda fruticosa) occurring on average approximately $10 \mathrm{~m}$ apart. This site is occasionally flooded by Carson Slough, although there are no noticeable stream-channel features in the photo. Instrument stand next to author contains sensors used to measure components at the energy balance of the surface. Eagle Mountain is prominent to the south.

Table 5. Measurement periods used for the energy-budget eddy-correlation technique.

[Numbers in table represent dates of the month; --, indicate no data were collected]

\begin{tabular}{cccccc}
\hline \multirow{2}{*}{$\begin{array}{c}\text { Site } \\
\text { number }\end{array}$} & \multicolumn{5}{c}{ Sampling dates } \\
\cline { 2 - 5 } & $\begin{array}{c}\text { June } \\
1983\end{array}$ & $\begin{array}{c}\text { October } \\
1983\end{array}$ & $\begin{array}{c}\text { January } \\
1984\end{array}$ & $\begin{array}{c}\text { April } \\
1984\end{array}$ & $\begin{array}{c}\text { September } \\
1984\end{array}$ \\
\hline 1 & $21-24$ & $14-16$ & $25-27$ & $21-23$ & $4-5$ \\
2 & $19-20$ & $14-15$ & $25-26$ & $21-23$ & $4-5$ \\
3 & -- & $16-18$ & $25-27$ & $23-25$ & $5-7$ \\
4 & -- & 16 & $27-29$ & $23-25$ & $5-7$ \\
5 & -- & -- & $25-27$ & $25-26$ & $7-9$ \\
6 & -- & -- & $26-27$ & $25-26$ & $7-9$ \\
7 & -- & -- & $27-28$ & -- & -- \\
\hline
\end{tabular}

effects of energy storage in the plant canopy and soil surface.

Equipment availability and time limitations caused variability in the length of measurement periods and the number of sites that were occupied during each trip. A summary of site occupation and measurement periods is listed in table 5 .

On January 25, 1984, between 0530 and 0930 hours, equipment failure at site 2 interrupted data collection. On the basis of flux occurrence at two other 


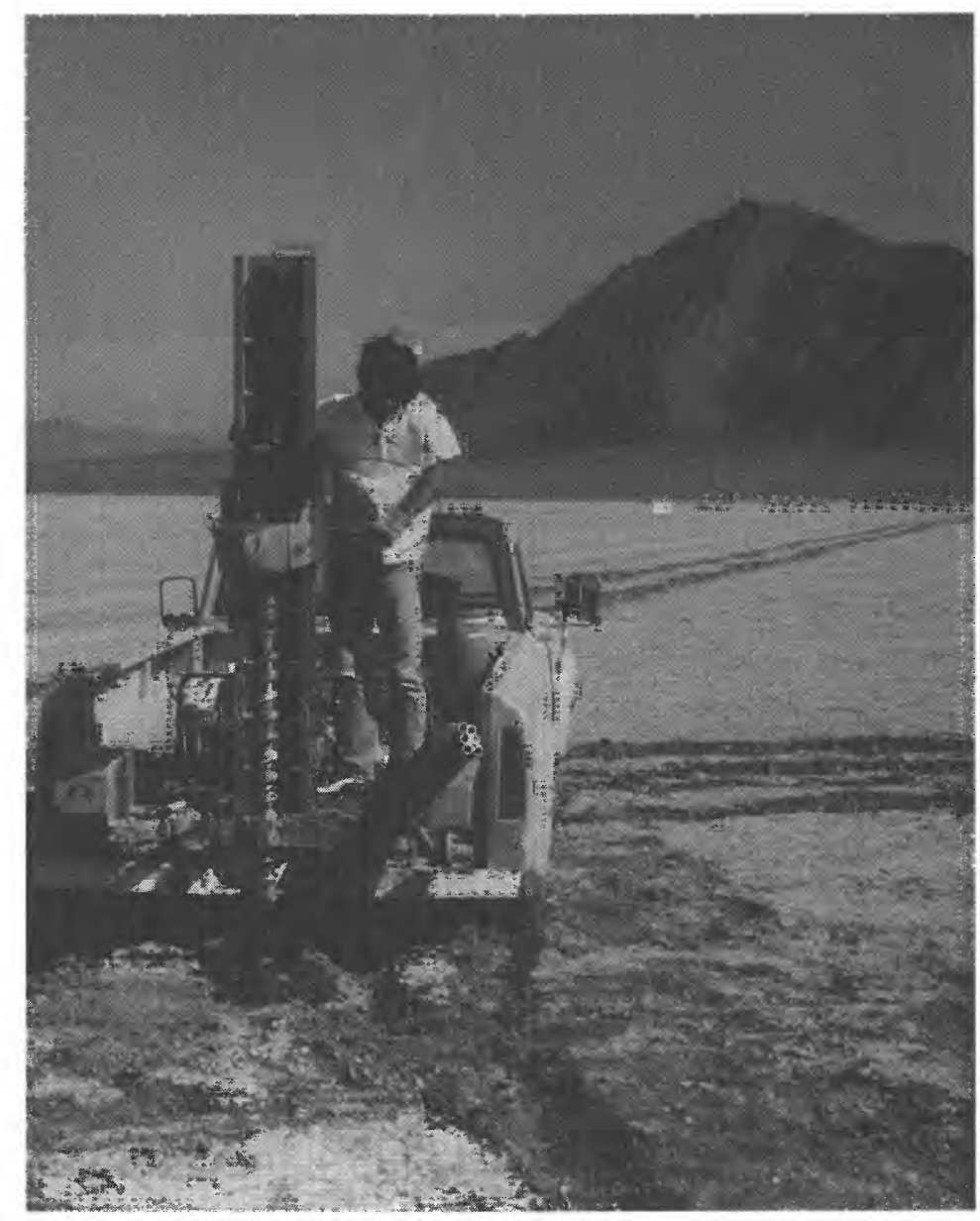

Figure 24. South-Central site showing puffy, porous surface. Drilling rig is being used to construct well GS-18. Eagle Mountain is seen to the south.

sites, the 0530 hours evapotranspiration (ET) value $(\approx 0)$ also was used at 0600,0630 , and 0700 hours. Linear interpolation then was used to estimate ET values at $0730,0800,0830,0900$, and 0930 hours. On January 28, 1984, between 0930 and 1030 hours, equipment failure at site 4 interrupted data collection. The missing ET values were estimated by using linear interpolation.

Typical 24-hour time series of the four flux densities measured at the North site in June 1983 are shown in figures $25 \mathrm{~A}-\mathrm{C}$. Net radiation, soil-heat flux, and sensible-heat flux all were positive during the day and negative during the night in this desert environment. Latent-heat flux, when estimated as a residual, fluctuates on a 30 -minute basis resulting from variation in sensible-heat flux and fluctuates on a slightly longer basis when changes in energy storage occur (for example, when the latent-heat flux became slightly negative shortly before sunset). The nighttime latent-heat flux averages usually were slightly positive, probably indicating a much smaller evaporation rate and a negligible transpiration rate.

\section{Results and Analysis}

Average ET rates are given in table 6 for the measurement periods and locations in table 5. Variation in rates is evident among the sites, especially in April and September 1984. Trends among most sites are not apparent; however, ET at the South-Central site tended to be greater than ET at the North site. Vegetated sites, on the average, did not have significantly higher ET rates than bare-soil sites. Apparently, evaporation is an equally effective transport mechanism at the surface as is transpiration, probably because of the 


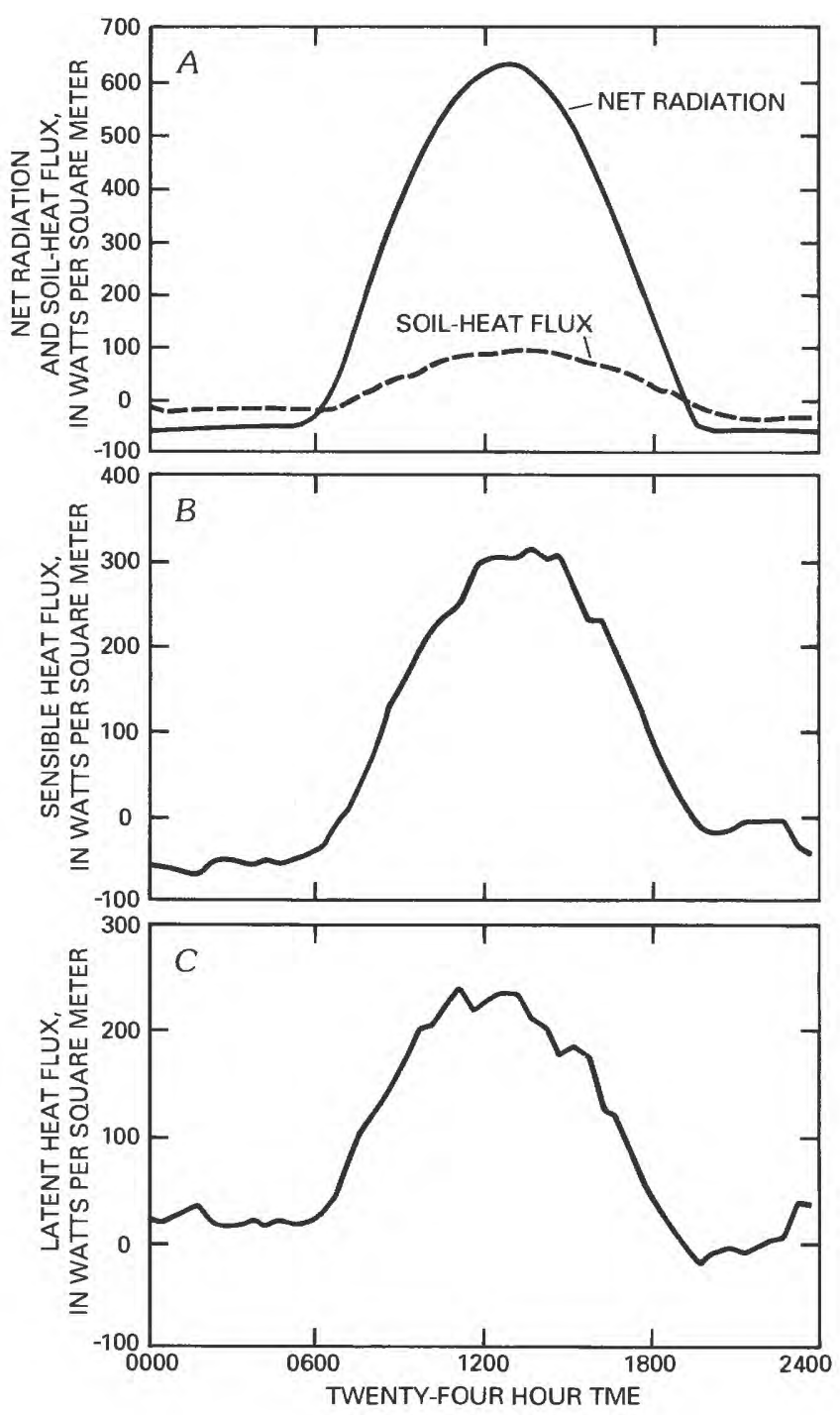

Figure 25. Typical 24-hour time series of $A$, net radiation and soil-heat flux; $B$, sensible-heat flux; and $C$, latent-heat flux.

sparse vegetation and shallow water table. Two methods were adopted to analyze the data to minimize bias in the results.

In the first method, only the North and South-Central sites were included, because measurements were made at these sites during every trip and because these two sites represent the two primary land-cover types on the playa. For this method, ET rates for the two sites were averaged together, and the averages were plotted against time. Rates were plotted on a monthly basis (fig. 26A), ignoring the year during which the data were collected (1983 or 1984).

In the second method, the ET rates from all sites measured for a given month were averaged together,

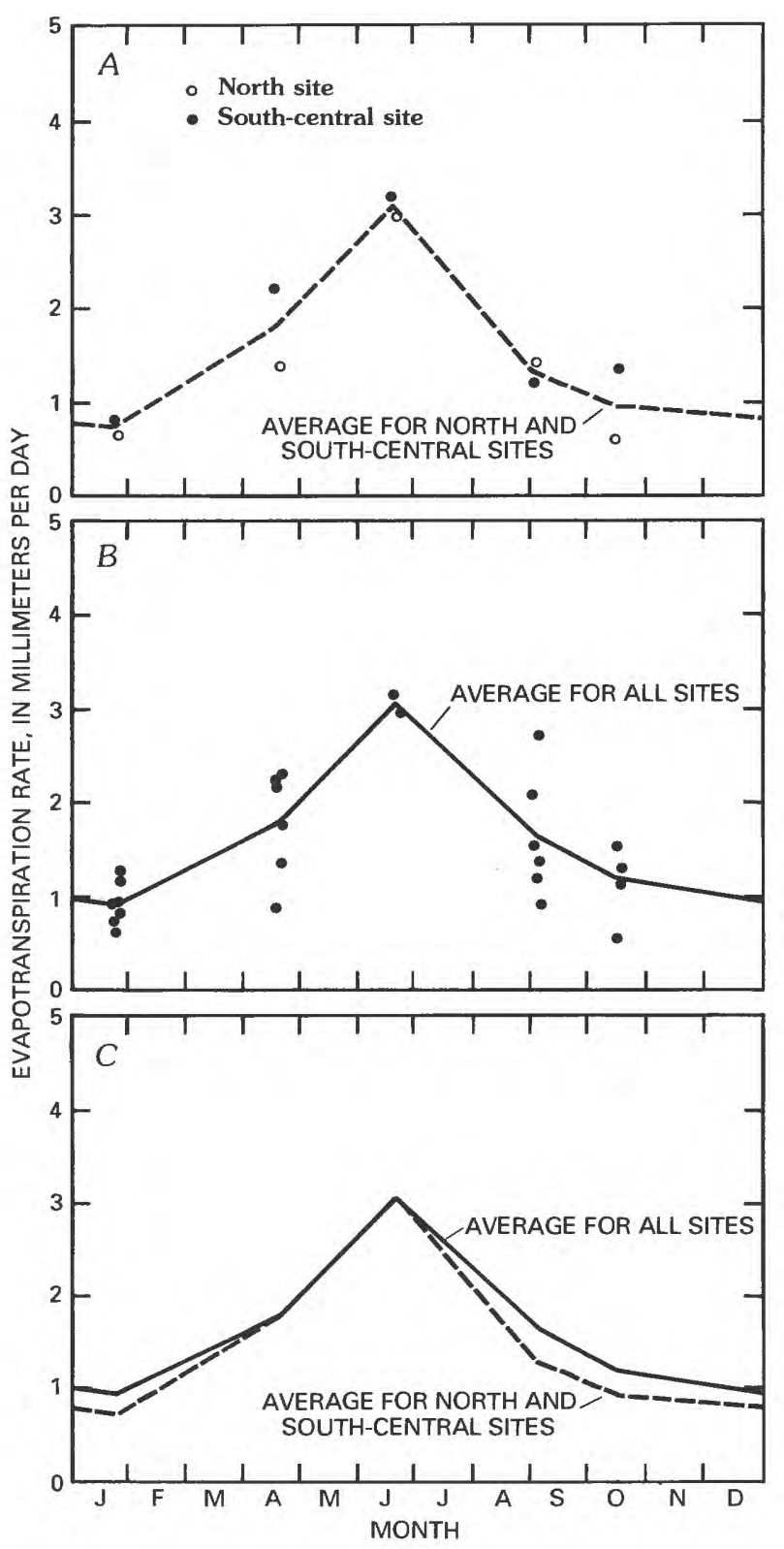

Figure 26. Evapotranspiration rates $A$, for the North and South-Central sites; $B$, for all sites; and $C$, for a comparison of the average for the North and South-Central sites with the average for all sites.

and the averages were plotted against time (fig. 26B). A comparison of the two methods is shown in figure $26 C$; general agreement exists between the two yearly curves.

Yearly ET totals were computed for each method by using linear interpolation between data points. Method 1 yielded a rate of $54 \mathrm{~cm} / \mathrm{a}$, or 0.15 $\mathrm{cm} / \mathrm{d}$; method 2 yielded a rate of $59 \mathrm{~cm} / \mathrm{a}$, or 0.16 $\mathrm{cm} / \mathrm{d}$. Because of the close agreement of the two 
Table 6. Average daily evapotranspiration rates estimated using the energy-budget eddy-correlation technique. $[-$, no data were collected]

\begin{tabular}{cccccc}
\hline \multirow{2}{*}{$\begin{array}{c}\text { Site } \\
\text { number }\end{array}$} & \multicolumn{5}{c}{ Evapotranspiration rate } \\
\cline { 2 - 6 } & $\begin{array}{c}\text { June } \\
1983\end{array}$ & $\begin{array}{c}\text { October } \\
1983\end{array}$ & $\begin{array}{c}\text { January } \\
1984\end{array}$ & $\begin{array}{c}\text { April } \\
1984\end{array}$ & $\begin{array}{c}\text { September } \\
1984\end{array}$ \\
\hline 1 & 3.0 & 0.5 & 0.6 & 1.4 & 1.4 \\
2 & 3.2 & 1.3 & .8 & 2.2 & 1.2 \\
3 & -- & 1.5 & .9 & .8 & 2.1 \\
4 & -- & 1.4 & .8 & 2.3 & .9 \\
5 & -- & -- & .9 & 2.2 & 1.6 \\
6 & -- & -- & 1.1 & 1.8 & 2.7 \\
7 & -- & -- & 1.3 & -- & -- \\
\hline
\end{tabular}

values, a rate of $59 \mathrm{~cm} / \mathrm{a}$ has been estimated as an upper limit of evapotranspiration at Franklin Lake playa. This value is considered to be an upper limit because the energy-balance eddy-correlation method historically has produced a value higher than some other methods, such as direct eddy-correlation and Bowen ratio (Weeks and others, 1987).

Experiments done by the author in Denver, Colo., during March 1986 to calibrate the Fritschen-type net radiometers using Eppley precision shortwave and longwave radiometers indicate that the Fritschen-type radiometers are less sensitive to longwave radiation than they are to shortwave radiation, producing an overestimate of net radiation. Such an overestimate could account for much of the discrepancy seen by Weeks and others (1987) between direct and energy-balance estimates of ET. If the Fritschen-type net radiometers have dissimilar longwave and shortwave sensitivities, the resulting errors in the 30-minute values of net radiation would be dependent upon the land-surface temperature. Land-surface temperature was not measured at Franklin Lake playa; therefore, a formal correction of net radiation was not possible. However, on the basis of subsequent experiments done by the author in which a Fritschen-type radiometer was used in a semiarid environment adjacent to a radiometer with equal sensitivities to longwave and shortwave radiation (as determined by the March 1986 calibration), an estimated correction of -20 percent to the measurement of net radiation is proposed. This proposed correction has not been observed by others (L.J. Fritschen, University of Washington, oral commun., 1986; E.T. Kanemasu, Kansas State University, oral commun.,
1987) using the same model of net radiometer under different environmental conditions, and further experiments need to be done to resolve the apparently inconsistent behavior of the radiometer observed by different investigators. Application of this -20 percent correction to all of the measurement periods at Franklin Lake decreases calculated ET by about 30 percent. The revised value for method 1 is $38 \mathrm{~cm} / \mathrm{a}$, or 0.10 $\mathrm{cm} / \mathrm{d}$.

On the basis of the data collected and evidence regarding the Fritschen-type net radiometer, the range of 38 to $41 \mathrm{~cm} / \mathrm{a}$ is suggested as the most reliable estimate of ET at Franklin Lake playa for 1983-84. Typically, eddy-transport fluxes, such as sensible-heat flux, can be measured to within \pm 10 percent, and $R_{n}$ and $G$ can be measured to within \pm 5 percent. A rigorous error analysis of energy-balance ET would apply the error bars to $R_{n}, G$, and $H$, and present either a worst-case or root-sum-square error in the calculated ET. However, because of the large, approximate correction suggested for $R_{n}$ (and because $R_{n}$ is the largest term in the energy-balance equation), such an error analysis would have little significance here. Also, other information (L.J. Fritschen, University of Washington, oral commun., 1986) suggests that the Fritschen-type net radiometer has equal sensitivities to longwave and shortwave radiation. Until this question is fully resolved, the rate of $59 \mathrm{~cm} / \mathrm{a}$ cannot be discounted entirely, and it is retained in the present analysis as a maximum estimate of ET. The ET values presented in this section represent averages for 1983-84; insufficient data are available to determine whether these values also represent long-term averages. 


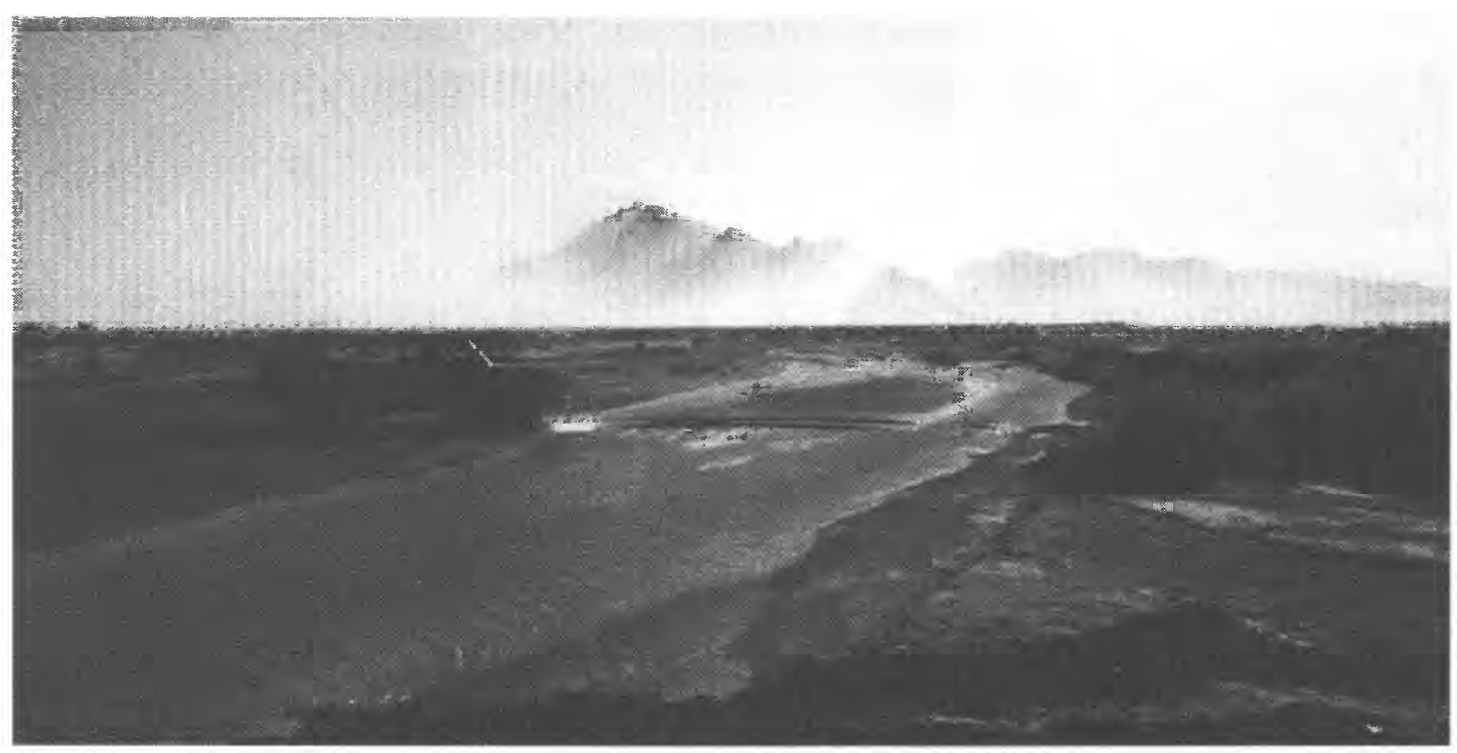

Figure 27. Eagle Mountain with dust blowing over the top as viewed from Franklin Lake playa.

The preceding section of the report identifies one technique for estimating evapotranspiration. Subsequent sections identify alternative techniques used to estimate evapotranspiration of ground water at Franklin Lake playa.

\section{Empirical Meteorological-Data Relations}

Potential evapotranspiration (PET) may be estimated from meteorological data using a variety of relations (Jensen, 1973, p. 63-111). Many of these empirical relations were determined by using comparisons between potential evapotranspiration and various meteorological variables; however, these relations vary in their suitability for site-specific estimation requirements. The initial objective of developing these methods was to estimate consumptive use of irrigation water by different types of crops under different climatic conditions. Empirical relations were developed for various well-watered crops to try to estimate evapotranspiration from meteorologic data. Because few plants grow at Franklin Lake playa (the majority of the playa is bare soil), and because the setting there is substantially different from that of a well-watered crop, the relations presented in this section probably greatly overestimate the quantity of evapotranspiration that, in this setting, primarily is bare-soil evaporation. Overestimation could occur because plants improve the efficiency of water movement from the unsaturated zone to the atmosphere, resulting in larger rates of water movement than occur from bare-soil conditions.

Meteorologic data used in estimating PET at Franklin Lake playa were supplied by the U.S.

National Weather Service, Nuclear Support Office (Douglas Soule, written commun., 1985), for weather stations located at Mercury, Nev. (lat $36^{\circ} 37^{\prime} \mathrm{N}$.; long $116^{\circ} 01^{\prime} \mathrm{W}$.; altitude 1,005 m); Boulder City, Nev. (lat $35^{\circ} 59^{\prime} \mathrm{N}$.; long $114^{\circ} 51^{\prime} \mathrm{W}$.; altitude $770 \mathrm{~m}$ ); and Silverpeak, Nev. (lat $38^{\circ} 57^{\prime} \mathrm{N}$.; long $119^{\circ} 20^{\prime} \mathrm{W}$.; altitude $1,299 \mathrm{~m}$ ). Meteorologic data for these three stations are listed in Czarnecki (1990, tables 1-3). The most complete record exists for Mercury, Nev.; however, pan-evaporation data do not exist for this station.

The annual climate at Franklin Lake playa is variable; average minimum temperatures during January are near freezing $\left(0^{\circ} \mathrm{C}\right)$ and maximum temperatures during June are higher than $54^{\circ} \mathrm{C}$. Peak precipitation occurs during the summer months as localized, sporadic thunderstorms. During winter months, regional storm systems cause precipitation to occur throughout the area. The estimated annual rainfall at Franklin Lake playa is less that $5 \mathrm{~cm} / \mathrm{a}$ (Winograd and Thordarson, 1975); however, intense localized thunderstorms can cause more than the average annual precipitation to fall in less than 1 hour. Winds are variable, and prevailing winds blow from the southwest and west during winter months; summer 
months bring localized convection, frequently causing "dust devils" to occur by early afternoon; they occur up to $50 \mathrm{~m}$ in height and easily are capable of lifting pea-sized gravel. Dust transported by strong northerly winds blowing over Eagle Mountain, which is $600 \mathrm{~m}$ higher than the playa surface, is shown in figure 27 .

Applicable techniques for estimating potential evapotranspiration from meteorological data may be classified by (1) temperature (Thornthwaite, 1948); (2) humidity (Ivanov, 1954; Papadakis, 1966); (3) pan evaporation (Doorenbos and Pruitt, 1974); (4) solar radiation (Turc, 1961; Jensen and Haise, 1963; Stephens, 1965); and (5) a combination of temperature, humidity, wind-speed, solar-radiation, and other various data (Penman, 1948; Behnke and Maxey, 1969; Linacre, 1969; and Linsley and others, 1975). Jensen (1973, p. 90-111) evaluated most of these methods, comparing results to direct measurements of evapotranspiration that were made by using weighing lysimeters for an extensively instrumented site at Kimberly, Idaho. Jensen's evaluation of each method included the percentage of difference between measured evapotranspiration and estimated potential evapotranspiration. Methods that gave smaller estimates of PET were deemed more suitable for estimating PET at Franklin Lake playa because most of the evapotranspiration at the playa occurs through bare-soil evaporation that typically is less than evapotranspiration would be for a well-watered crop under identical meteorological conditions. Many of the methods presented by Jensen were not used for this reason and, also, because of a lack of appropriate meteorologic data needed for input to these methods.

Not all the empirical methods used to estimate PET were developed using metric units and, for consistency, the original units were retained and used in this report. Also, the original measurements of temperature from the U.S. Weather Service were reported in degrees Fahrenheit and are also retained in this report to facilitate comparison. Units for constants used in the empirical equations are listed in the Appendix.

\section{Temperature}

Jensen's analysis of the Thornthwaite (1948) method indicates that the method "****should not be used in areas that are not similar to the east-central United States. However, because it can be computed from temperature and latitude it has been one of the most misused empirical equations generating inaccurate estimates of evapotranspiration for arid and semiarid irrigated areas***." For this reason, the Thornthwaite method was not used.

\section{Humidity}

The technique of Ivanov (1954) was used to estimate PET at Franklin Lake playa. The governing empirical relation for this method is

$$
\text { PET }=0.0018(25+T)^{2}(100-\text { r.h. }),
$$

where

PET is the potential evapotranspiration, in millimeters per month;

$T$ is the mean monthly temperature, in degrees Celsius;

and

r.h. is the mean monthly relative humidity, in percent.

Results from this method are listed in table 7. Jensen (1973, p. 96) observed that this method of estimating PET produced a result 22 percent lower than the result measured with a weighing lysimeter. The average annual estimate for PET using this method was 0.75 $\mathrm{cm} / \mathrm{d}$.

The method of Papadakis (1966) uses the following relation:

$$
\operatorname{PET}=0.5625\left(e_{\max }-e_{z}\right)
$$

where

PET is the potential evapotranspiration, in centimeters per month;

$e_{\max }$ is the saturation vapor pressure, in millibars correspondingtoaverage daily maximum temperature;

and

$e_{\mathrm{z}}$ is the average vapor pressure for the month, in millibars.

Monthly estimates of PET made using this technique are listed in tables $8-10$. Table 8 contains data from Mercury, NV; tables 9 and 10 contain data from Boulder City, NV. Saturation-vapor pressures were obtained from Jensen (1973, table A3, p. 189). The 
Table 7. Estimated potential evaporation at Franklin Lake playa using the technique of Ivanov (1954, as in Jensen, 1973, p. 96), and Turc (1961, as in Jensen, 1973, p. 100) for meteorologic data for Mercury, Nevada.

[ ${ }^{\mathrm{C}}$, degrees Celsius; ly/d, langleys per day; $\mathrm{mm} / \mathrm{mo}$, millimeters per month; $\mathrm{cm} / \mathrm{d}$, centimeters per day]

\begin{tabular}{|c|c|c|c|c|c|c|}
\hline \multirow[b]{2}{*}{ Month } & \multirow{2}{*}{$\begin{array}{l}\text { Average monthly } \\
\text { temperature } \\
\left({ }^{\circ} \mathrm{C}\right)\end{array}$} & \multirow{2}{*}{$\begin{array}{l}\text { Relative } \\
\text { humidity } \\
\text { (percent) }\end{array}$} & \multirow{2}{*}{$\begin{array}{l}\text { Solar } \\
\text { radiation } \\
(1 \mathrm{y} / \mathrm{d})\end{array}$} & \multicolumn{3}{|c|}{ Potential evapotranspiration } \\
\hline & & & & $\frac{\text { Ivanov }}{(\mathrm{mm} / \mathrm{mo})}$ & $\frac{(1954)}{(\mathrm{cm} / \mathrm{d})}$ & $\frac{\text { Turc (1961) }}{(\mathrm{cm} / \mathrm{d})}$ \\
\hline January & 6.4 & 50.8 & 345 & 87.7 & 0.28 & 0.15 \\
\hline February & 8.5 & 48.3 & 496 & 104.5 & .37 & .26 \\
\hline March & 10.1 & 48.0 & 568 & 115.0 & .37 & .33 \\
\hline April & 14.7 & 30.8 & 700 & 196.7 & .66 & .62 \\
\hline May & 19.6 & 29.8 & 742 & 251.0 & .81 & .75 \\
\hline June & 25.7 & 16.3 & 800 & 387.8 & 1.29 & 1.03 \\
\hline July & 29.2 & 20.0 & 761 & 422.5 & 1.36 & 1.00 \\
\hline August & 27.9 & 24.8 & 697 & 378.9 & 1.22 & .86 \\
\hline September & 24.0 & 27.5 & 603 & 313.3 & 1.04 & .69 \\
\hline October & 17.7 & 27.8 & 477 & 236.7 & .76 & .49 \\
\hline November & 10.4 & 36.8 & 380 & 142.6 & .48 & .27 \\
\hline \multirow[t]{2}{*}{ December } & 7.2 & 42.8 & 313 & 107.0 & .35 & .17 \\
\hline & & & & Average: & 0.75 & 0.55 \\
\hline
\end{tabular}

Table 8. Estimated potential evapotranspiration at Franklin Lake playa using the technique of Papadakis (1966, as in Jensen, 1973, p. 97) for meteorologic data for Mercury, Nevada.

[ $T_{\max }$, average monthly maximum temperature in degrees Celsius; $e_{\text {max }}^{\circ}$, saturated vapor pressure over water corresponding to $T_{\max } ; T_{\min }$, average monthly minimum temperature in ${ }^{\circ} \mathrm{C}$ less $2^{\circ} \mathrm{C} ; e_{\mathrm{z}}$, vapor pressure over water corresponding to $T_{\min } ; \mathrm{PET}$, potential evapotranspiration; $\mathrm{mb}$, millibars; $\mathrm{cm} / \mathrm{mo}$, centimeters per month; $\mathrm{cm} / \mathrm{d}$, centimeters per day]

\begin{tabular}{|c|c|c|c|c|c|c|}
\hline \multirow{2}{*}{ Month } & \multirow{2}{*}{$T_{\max }\left({ }^{\circ} \mathrm{C}\right)$} & \multirow{2}{*}{$\begin{array}{c}{ }^{1} e^{0}{ }_{\max } \\
(\mathrm{mb})\end{array}$} & \multirow{2}{*}{$\begin{array}{l}T_{\text {min }} \\
\left({ }^{\circ} \mathrm{C}\right)\end{array}$} & \multirow{2}{*}{$\begin{array}{c}e_{z} \\
(m b)\end{array}$} & \multicolumn{2}{|c|}{ PET } \\
\hline & & & & & $(\mathrm{cm} / \mathrm{mo})$ & $(\mathrm{cm} / \mathrm{d})$ \\
\hline $\begin{array}{l}\text { January } \\
\text { February } \\
\text { March } \\
\text { April } \\
\text { May } \\
\text { June }\end{array}$ & $\begin{array}{l}12.3 \\
14.9 \\
16.2 \\
21.8 \\
26.9 \\
33.7\end{array}$ & $\begin{array}{l}14.3 \\
17.0 \\
18.4 \\
26.1 \\
35.4 \\
52.3\end{array}$ & $\begin{array}{r}-1.3 \\
.1 \\
1.9 \\
5.6 \\
10.3 \\
15.8\end{array}$ & $\begin{array}{l}6.0 \\
6.16 \\
7.02 \\
9.11 \\
12.5 \\
18.0\end{array}$ & $\begin{array}{r}4.7 \\
6.1 \\
6.4 \\
9.6 \\
12.9 \\
19.3\end{array}$ & $\begin{array}{r}0.15 \\
.22 \\
.21 \\
.32 \\
.42 \\
.64\end{array}$ \\
\hline $\begin{array}{l}\text { July } \\
\text { August } \\
\text { September } \\
\text { October } \\
\text { November } \\
\text { December }\end{array}$ & $\begin{array}{l}37.2 \\
35.7 \\
31.8 \\
25.3 \\
17.3 \\
13.9\end{array}$ & $\begin{array}{l}63.5 \\
58.4 \\
47.0 \\
32.2 \\
19.8 \\
15.9\end{array}$ & $\begin{array}{r}19.1 \\
18.1 \\
14.2 \\
8.0 \\
1.5 \\
-1.4\end{array}$ & $\begin{array}{c}22.1 \\
20.8 \\
16.2 \\
10.7 \\
6.82 \\
6.0\end{array}$ & $\begin{array}{r}23.3 \\
21.2 \\
17.3 \\
12.1 \\
7.3 \\
5.6\end{array}$ & $\begin{array}{l}.75 \\
.68 \\
.58 \\
.39 \\
.24 \\
.18 \\
\end{array}$ \\
\hline & & & & & Avera & 0.40 \\
\hline
\end{tabular}

1Jensen (1973), table A3, p. 189. 
Table 9. Estimated potential evapotranspiration at Franklin Lake playa using the technique of Papadakis (1966, as in Jensen, 1973, p. 97) for meteorologic data for Boulder City, Nevada, during 1982.

[ $T_{\text {max }}$, average monthly maximum temperature in degrees Celsius; $e^{\circ} \max$, saturated vapor pressure over water corresponding to $T_{\max } ; T_{\min }$, average monthly minimum temperature in ${ }^{\circ} \mathrm{C}$ less $2^{\circ} \mathrm{C} ; e_{\mathrm{Z}}$, vapor pressure over water corresponding to $T_{\min } ; \mathrm{PET}$, potential evapotranspiration; $\mathrm{mb}$, millibars; $\mathrm{cm} / \mathrm{mo}$, centimeters per month; $\mathrm{cm} / \mathrm{d}$, centimeters per day]

\begin{tabular}{|c|c|c|c|c|c|c|}
\hline \multirow{2}{*}{ Month } & \multirow{2}{*}{$T_{\max }$} & \multirow{2}{*}{$\begin{array}{c}{ }^{1} \mathrm{e}_{\max }^{0} \\
(\mathrm{mb})\end{array}$} & \multirow{2}{*}{$\begin{array}{l}T_{\text {min }} \\
\left({ }^{\circ} \mathrm{C}\right)\end{array}$} & \multirow{2}{*}{$\begin{array}{r}{ }^{1} e_{z} \\
(\mathrm{mb})\end{array}$} & \multicolumn{2}{|c|}{ PET } \\
\hline & & & & & $(\mathrm{cm} / \mathrm{mo})$ & $(\mathrm{cm} / \mathrm{d})$ \\
\hline $\begin{array}{l}\text { January } \\
\text { February } \\
\text { March } \\
\text { April } \\
\text { May } \\
\text { June }\end{array}$ & $\begin{array}{l}11.1 \\
15.1 \\
17.8 \\
24.3 \\
28.1 \\
31.4\end{array}$ & $\begin{array}{l}13.2 \\
17.2 \\
20.4 \\
30.4 \\
38.0 \\
45.9\end{array}$ & $\begin{array}{r}-0.8 \\
2.2 \\
3.2 \\
5.2 \\
9.7 \\
12.2\end{array}$ & $\begin{array}{l}6.0 \\
7.17 \\
7.70 \\
8.86 \\
12.0 \\
14.2\end{array}$ & $\begin{array}{r}4.0 \\
5.6 \\
7.1 \\
12.1 \\
14.6 \\
17.8\end{array}$ & $\begin{array}{r}0.13 \\
.20 \\
.23 \\
.40 \\
.47 \\
.59\end{array}$ \\
\hline $\begin{array}{l}\text { July } \\
\text { August } \\
\text { September } \\
\text { October } \\
\text { November } \\
\text { December }\end{array}$ & $\begin{array}{l}32.7 \\
33.4 \\
29.2 \\
21.8 \\
14.8 \\
11.9\end{array}$ & $\begin{array}{l}49.4 \\
51.1 \\
40.5 \\
26.1 \\
16.8 \\
13.9\end{array}$ & $\begin{array}{r}16.0 \\
16.7 \\
12.6 \\
5.3 \\
1.0 \\
-1.2\end{array}$ & $\begin{array}{c}18.2 \\
19.0 \\
14.6 \\
8.92 \\
6.58 \\
6.00\end{array}$ & $\begin{array}{r}17.6 \\
18.1 \\
14.6 \\
9.7 \\
5.8 \\
4.4\end{array}$ & $\begin{array}{l}.57 \\
.58 \\
.49 \\
.31 \\
.19 \\
.14\end{array}$ \\
\hline December & & & & & $\mathrm{Av}$ & 0.36 \\
\hline
\end{tabular}

\section{Jensen (1973), table A3, p. 189.}

Table 10. Estimated potential evapotranspiration at Franklin Lake playa using the technique of Papadakis (1966, as in Jensen, 1973, p. 97) for meteorologic data for Boulder City, Nevada, during 1983.

[ $T_{\max }$, average monthly maximum temperature in degrees Celsius; $e_{\text {max }}^{\circ}$, saturated vapor pressure over water corresponding to $T_{\max } ; T_{\min }$, average monthly minimum temperature in ${ }^{\circ} \mathrm{C}$ less $2^{\circ} \mathrm{C} ; e_{z}$, vapor pressure over water corresponding to $T_{\min } ; \mathrm{PET}$, potential evapotranspiration; $\mathrm{mb}$, millibars; $\mathrm{cm} / \mathrm{mo}$, centimeters per month; $\mathrm{cm} / \mathrm{d}$, centimeters per day; --, missing data]

\begin{tabular}{|c|c|c|c|c|c|c|}
\hline \multirow{2}{*}{ Month } & \multirow{2}{*}{$\begin{array}{l}T_{\max } \\
\left({ }^{\circ} \mathrm{C}\right)\end{array}$} & \multirow{2}{*}{${ }_{(\mathrm{mb})}^{1 e^{0}}$} & \multirow{2}{*}{$T_{\min }$} & \multirow{2}{*}{${ }_{(\mathrm{mb})}^{{ }^{1} e}$} & \multicolumn{2}{|c|}{ PET } \\
\hline & & & & & $(\mathrm{cm} / \mathrm{mo})$ & $(\mathrm{cm} / \mathrm{d})$ \\
\hline $\begin{array}{l}\text { January } \\
\text { February } \\
\text { March } \\
\text { April } \\
\text { May } \\
\text { June }\end{array}$ & $\begin{array}{l}14.4 \\
20.0 \\
23.7 \\
29.8 \\
32.1\end{array}$ & $\begin{array}{c}-- \\
16.4 \\
23.4 \\
29.3 \\
41.9 \\
47.8\end{array}$ & $\begin{array}{r}-- \\
2.4 \\
4.1 \\
3.4 \\
8.6 \\
12.2\end{array}$ & $\begin{array}{l}--- \\
7.27 \\
8.20 \\
7.81 \\
11.2 \\
14.2\end{array}$ & $\begin{array}{l}-- \\
5.14 \\
8.55 \\
12.1 \\
17.3 \\
18.9\end{array}$ & $\begin{array}{r}(2) \\
0.18 \\
.28 \\
.40 \\
.56 \\
.63\end{array}$ \\
\hline $\begin{array}{l}\text { July } \\
\text { August } \\
\text { September } \\
\text { October } \\
\text { November } \\
\text { December }\end{array}$ & $\begin{array}{l}33.9 \\
34.0 \\
31.6 \\
24.8 \\
16.3 \\
12.5\end{array}$ & $\begin{array}{l}52.9 \\
53.2 \\
46.5 \\
31.3 \\
18.5 \\
14.5\end{array}$ & $\begin{array}{r}14.2 \\
16.8 \\
15.0 \\
8.9 \\
3.6 \\
0.1\end{array}$ & $\begin{array}{c}16.2 \\
19.1 \\
17.1 \\
11.4 \\
7.92 \\
6.15\end{array}$ & $\begin{array}{r}20.6 \\
19.2 \\
16.5 \\
11.2 \\
6.0 \\
4.7\end{array}$ & $\begin{array}{l}.67 \\
.62 \\
.55 \\
.36 \\
.20 \\
.15\end{array}$ \\
\hline & & & & & Aver & 0.40 \\
\hline
\end{tabular}

1Jensen (1973), Table A3, p. 189.

2Missing PET value estimated as 0.15 centimeter per day. 
Table 11. Estimated potential evapotranspiration at Franklin Lake playa using the technique of Doorenbos and Pruitt (1974, as in Jensen, 1973, p. 76, 101-102) for pan evaporation data for Boulder City, Nevada, 1982 through 1983.

[Mean relative humidity, 19 percent; mean wind speed, $363 \mathrm{~km}$ per day; $E_{\mathrm{p}}$, pan evaporation; $C_{\mathrm{et}}$, pan coefficient (from Jensen, 1973 , table 6.3 p. 76), 0.45; cm/d, centimeters per day; --, missing data]

\begin{tabular}{|c|c|c|c|c|}
\hline Month & ${ }^{E_{p}} \underset{(\mathrm{cm} / \mathrm{d})}{(1982)}$ & $\begin{array}{c}C_{\text {et }} \times E_{p} \\
(\mathrm{~cm} / \mathrm{d})\end{array}$ & $E_{\mathrm{p}} \underset{(\mathrm{cm} / \mathrm{d})}{(1983)}$ & $\begin{array}{c}C_{\text {et }} \times E_{p} \\
(\mathrm{~cm} / \mathrm{d})\end{array}$ \\
\hline $\begin{array}{l}\text { January } \\
\text { February } \\
\text { March } \\
\text { April } \\
\text { May } \\
\text { June }\end{array}$ & $\begin{array}{c}0.29 \\
.36 \\
.50 \\
.82 \\
1.07 \\
1.21\end{array}$ & $\begin{array}{r}0.13 \\
.16 \\
.22 \\
.37 \\
.48 \\
.54\end{array}$ & $\begin{array}{r}-- \\
0.28 \\
.50 \\
.70 \\
1.14 \\
1.39\end{array}$ & $\begin{array}{l}-- \\
0.13 \\
.22 \\
.32 \\
.51 \\
.63\end{array}$ \\
\hline $\begin{array}{l}\text { July } \\
\text { August } \\
\text { September } \\
\text { October } \\
\text { November } \\
\text { December }\end{array}$ & $\begin{array}{l}1.18 \\
1.03 \\
.75 \\
.56 \\
.31 \\
-.\end{array}$ & $\begin{array}{l}.53 \\
.46 \\
.34 \\
.25 \\
.14 \\
.-\end{array}$ & $\begin{array}{r}1.43 \\
.82 \\
.86 \\
.56 \\
.43 \\
.25\end{array}$ & $\begin{array}{l}.64 \\
.37 \\
.39 \\
.25 \\
.19 \\
.11\end{array}$ \\
\hline December & & 0.27 & & 0.34 \\
\hline
\end{tabular}

average annual estimates for PET using this method varied from 0.36 to $0.40 \mathrm{~cm} / \mathrm{d}$.

\section{Pan Evaporation}

Doorenbos and Pruitt (1974) proposed the following relation for obtaining PET:

$$
\mathrm{PET}=C_{\mathrm{et}} E_{\mathrm{p}}
$$

where

PET is potential evapotranspiration, in centimeters per day;

$C_{\text {et }}$ is a dimensionless pan coefficient that is determined from Jensen (1973, table 6.3,p. 76) and is dependent on wind speed, relative humidity, whether or not the land is dry, and the length of fetch upwind of

and the pan;

$E_{\mathrm{p}}$ is the measured pan evaporation, in centimeters per day.

This method was applied to pan-evaporation data for Boulder City, Nev.; results are listed in table 11.

When this method was applied, a major assumption was that the pan evaporation is identical to the pan evaporation that would be measured at Franklin Lake playa. The average annual estimate for PET using this method varied from 0.27 to $0.34 \mathrm{~cm} / \mathrm{d}$.

\section{Solar Radiation}

Solar-radiation data used in estimating potential evapotranspiration at Franklin Lake playa were from table 3.1 of Jensen (1973, p. 22-23). These data were calculated for specific northern latitudes for cloudless skies. Values used are those corresponding to $35^{\circ} \mathrm{N}$ latitude.

Turc (1961) developed the relation:

$$
\begin{aligned}
& \operatorname{PET}=0.013(T /[T+15])(R+50) \\
& (1+[50-\text { r.h. }] / 70),
\end{aligned}
$$

where

PET is potential evapotranspiration, in millimeters per day;

$T$ is mean monthly temperature, in degrees Celsius;

$R$ is solar radiation, in langleys per day; and r.h. is mean monthly relative humidity, in percent. 
Table 12. Estimated potential evapotranspiration at Franklin Lake playa using the technique of Jensen and Haise (1963, as in Jensen, 1973, p. 99) and Stephens (1965, as in Jensen, 1973, p. 100) for meteorological data.

$\left[e_{1}\right.$ and $e_{2}$, saturation vapor pressures at the mean monthly maximum and mean monthly minimum temperatures; ${ }^{\circ} \mathrm{C}$, degrees Celsius; $\mathrm{mb}$, millibars; ly/d, langleys per day; $\mathrm{cm} / \mathrm{d}$, centimeters per day]

\begin{tabular}{|c|c|c|c|c|c|c|}
\hline \multirow[b]{2}{*}{ Month } & \multirow[b]{2}{*}{$\begin{array}{l}\text { Mean monthly } \\
\text { temperature } \\
\quad\left({ }^{\circ} \mathrm{C}\right)\end{array}$} & \multirow[b]{2}{*}{$\begin{array}{l}{ }^{1} e_{1} \\
(\mathrm{mb})\end{array}$} & \multirow[b]{2}{*}{$\begin{array}{l}{ }^{1} e_{2} \\
(m b)\end{array}$} & \multirow[b]{2}{*}{$\begin{array}{l}\text { Solar } \\
\text { radiation } \\
(1 y / d)\end{array}$} & \multicolumn{2}{|c|}{ PET } \\
\hline & & & & & $\begin{array}{l}\text { Jensen and } \\
\text { Haise method } \\
(\mathrm{cm} / \mathrm{d})\end{array}$ & $\begin{array}{l}\text { Stephens } \\
\text { method } \\
(\mathrm{cm} / \mathrm{d})\end{array}$ \\
\hline $\begin{array}{l}\text { January } \\
\text { February } \\
\text { March } \\
\text { April } \\
\text { May } \\
\text { June }\end{array}$ & $\begin{array}{r}6.4 \\
8.5 \\
10.1 \\
14.7 \\
19.6 \\
25.7\end{array}$ & $\begin{array}{l}14.3 \\
17.0 \\
18.4 \\
26.1 \\
35.4 \\
52.3\end{array}$ & $\begin{array}{l}6.44 \\
7.12 \\
8.09 \\
10.5 \\
14.3 \\
20.4\end{array}$ & $\begin{array}{l}345 \\
496 \\
568 \\
700 \\
742 \\
800\end{array}$ & $\begin{array}{r}0.09 \\
.17 \\
.23 \\
.46 \\
.69 \\
1.09\end{array}$ & $\begin{array}{r}0.14 \\
.24 \\
.32 \\
.53 \\
.72 \\
.98\end{array}$ \\
\hline $\begin{array}{l}\text { July } \\
\text { August } \\
\text { September } \\
\text { October } \\
\text { November } \\
\text { December }\end{array}$ & $\begin{array}{r}29.2 \\
27.9 \\
24.0 \\
17.7 \\
10.4 \\
7.2\end{array}$ & $\begin{array}{l}63.5 \\
58.4 \\
47.0 \\
32.2 \\
19.8 \\
15.9\end{array}$ & $\begin{array}{l}25.0 \\
23.5 \\
18.4 \\
12.3 \\
7.86 \\
6.39\end{array}$ & $\begin{array}{l}761 \\
697 \\
603 \\
474 \\
380 \\
313\end{array}$ & $\begin{array}{r}1.23 \\
1.05 \\
.75 \\
.40 \\
.17 \\
.10 \\
\end{array}$ & $\begin{array}{r}1.05 \\
.92 \\
.70 \\
.42 \\
.22 \\
.14 \\
\end{array}$ \\
\hline & & & & Average: & 0.54 & 0.53 \\
\hline
\end{tabular}

1Jensen (1973), table A3, p. 189.

Turc's method (1961) gave estimates of PET that were 33 percent less than that measured by Jensen (1973).

Monthly estimates of PET for Franklin Lake playa are listed in table 7 the yearly average estimated PET for Franklin Lake playa using this method was $0.55 \mathrm{~cm} / \mathrm{d}$.

Jensen and Haise (1963) developed an empirical relation to estimate PET from solar radiation, temperature, and saturation vapor pressure, based on numerous measurements of evapotranspiration from soil-sampling procedures, correlated with well-watered crops of various types. From these observations, they derived the relations:

$$
\begin{gathered}
\mathrm{PET}=0.00171 C_{T}\left(T-T_{X}\right) R, \\
C_{T}=1 /\left(C_{1}+C_{2} C_{H}\right), \\
T_{\mathrm{x}}=-2.5-0.14\left(e_{2}-e_{1}\right) \text { alt. } / 550, \\
\mathrm{C}_{1}=38-\left(2^{\circ} \mathrm{C} \times \text { alt } . / 305\right) \\
C_{2}=7.6^{\circ} \mathrm{C} \\
C_{H}=C_{3} /\left(e_{2}-e_{1}\right),
\end{gathered}
$$

where

PET is potential evapotranspiration, in centimeters per day;

$T$ is mean monthly temperature, in degrees Celísius;

$R$ is solar radiation, in langleys per day;

alt. is the altitude, in meters, of the measuring point;

$C_{3}$ is a constant equal to 50 millibars;

$e_{2}$ is the saturation vapor pressure, in millibars for the mean maximum air temperature;

and

$e_{1}$ is the saturation vapor pressure, in millibars for the mean minimum air temperature.

Estimates of evapotranspiration made using the method of Jensen and Haise (1963) are listed in table 12. The altitude used in these calculations was assumed to be that of Franklin Lake playa (approximately $610 \mathrm{~m}$ ). The average annual estimate for PET using this method was $0.54 \mathrm{~cm} / \mathrm{d}$. 
Table 13. Estimated potential evapotranspiration at Franklin Lake playa using the technique of Benke and Maxey (1969, as in Jensen, 1973, p. 97) for meteorological data.

$\left[{ }^{\circ} \mathrm{C}\right.$, degrees Celsius; $W_{0}$, monthly onsite water-requirement-characteristic constant for lat $35^{\circ} \mathrm{N}$.; $\mathrm{cm} / \mathrm{d}$, centimeters per day]

\begin{tabular}{lccc}
\hline Month & $\begin{array}{c}\text { Average monthly } \\
\text { temperature } \\
\left({ }^{\circ} \mathrm{C}\right)\end{array}$ & $w_{0}$ & $\begin{array}{c}\text { Potential } \\
\text { evapotranspiration } \\
(\mathrm{cm} / \mathrm{d})\end{array}$ \\
\hline January & 6.4 & 0.032 & 0.11 \\
February & 8.5 & .042 & .19 \\
March & 10.1 & .060 & .32 \\
April & 14.7 & .073 & .56 \\
May & 19.6 & .083 & .86 \\
June & 25.7 & .083 & 1.12 \\
& & & 1.23 \\
July & 29.2 & .083 & 1.03 \\
August & 27.9 & .070 & .85 \\
September & 24.0 & .067 & .46 \\
October & 17.7 & .049 & .19 \\
November & 10.4 & .034 & .10 \\
December & 7.2 & .027 & Average: \\
& & & 0.58 \\
\hline
\end{tabular}

Stephens (1965) proposed the following relation to calculate PET:

$$
\mathrm{PET}=(0.014 T-0.37) \times R / 1500,
$$

where

PET is potential evapotranspiration, in inches per day;

$T$ is mean monthly air temperature, in degrees Fahrenheit;

and

$R$ is mean monthly solar radiation, in langleys per day.

Jensen's (1973) application of this method to the Kimberly, Idaho, experimental data gave estimates of evapotranspiration that were 20 percent lower than measured. Estimates for Franklin Lake playa are listed in table 12. The average annual estimate for PET using the method of Stephens (1965) is 0.53 $\mathrm{cm} / \mathrm{d}$.

\section{Combination Methods}

Various methods were developed by investigators to estimate PET using combinations of temperature, humidity, wind-speed, solar-radiation, and other data. Behnke and Maxey (1969) developed a relation for estimating PET from monthly field-water-requirement characteristic constants and the simulated wet-bulb depression, as

$$
\mathrm{PET}=T / 1.9 \times W_{\mathrm{o}}
$$

where

PET is potential evapotranspiration, in centimeters per day;

$T / 1.9$ is the simulated wet-bulb depression; and

$W_{\mathrm{o}}$ is the monthly field-water-requirement characteristic constant, dimensionless.

Values for $W_{\mathrm{o}}$ vary with latitude and time during the year (Jensen, 1973, p. 73, table 6.2). Jensen (1973) reported that this method overestimated evapotranspiration by 15 percent. Values of potential evapotranspiration for Franklin Lake playa obtained by using this method are listed in table 13. The annual average value for PET is $0.58 \mathrm{~cm} / \mathrm{d}$. Temperature data for Mercury, Nev., were used in these estimates. 
Table 14. Estimated potential evapotranspiration at Franklin Lake playa using the estimation technique of Linacre (1969, see Jensen, 1973, p. 71) for temperature data for Mercury, Nevada.

$\left[{ }^{\circ} \mathrm{C}\right.$, degrees Celsius; $\mathrm{km} / \mathrm{h}$, kilometer per hour; ly/d, langley per day; $\mathrm{cm} / \mathrm{d}$, centimeters per day; Source, D.A. Soule, National Weather Service, Nuclear Support Office, written commun., 1985]

\begin{tabular}{|c|c|c|c|c|c|}
\hline \multirow[t]{2}{*}{ Month } & \multicolumn{2}{|c|}{$\begin{array}{l}\text { Average monthly } \\
\text { temperature }\left({ }^{\circ} \mathrm{C}\right)\end{array}$} & \multirow{2}{*}{$\begin{array}{l}\begin{array}{l}\text { Wind } \\
\text { speed }\end{array} \\
(\mathrm{km} / \mathrm{h})\end{array}$} & \multirow{2}{*}{$\begin{array}{l}\text { Solar } \\
\text { radiation } \\
(1 y / d)\end{array}$} & \multirow{2}{*}{$\begin{array}{c}\text { Potential } \\
\text { evapo- } \\
\text { trans- } \\
\text { piration } \\
(\mathrm{cm} / \mathrm{d})\end{array}$} \\
\hline & maximum & minimum & & & \\
\hline January & 12.3 & 0.67 & 328.3 & 345 & 0.55 \\
\hline February & 14.9 & 2.1 & 355.3 & 496 & .75 \\
\hline March & 16.2 & 3.9 & 363.0 & 568 & .83 \\
\hline April & 21.8 & 7.6 & 401.7 & 700 & 1.12 \\
\hline May & 26.9 & 12.3 & 370.8 & 742 & 1.24 \\
\hline June & 33.7 & 17.8 & 424.9 & 800 & 1.60 \\
\hline July & 37.2 & 21.1 & 363.0 & 761 & 1.56 \\
\hline August & 35.7 & 20.1 & 343.8 & 697 & 1.40 \\
\hline September & 31.8 & 16.2 & 322.2 & 603 & 1.17 \\
\hline October & 25.3 & 10.0 & 324.4 & 474 & .89 \\
\hline November & 17.3 & 3.5 & 316.7 & 380 & .66 \\
\hline \multirow[t]{2}{*}{ December } & 13.9 & 0.6 & 297.4 & 313 & .54 \\
\hline & & & & Average: & 1.02 \\
\hline
\end{tabular}

\section{Jensen (1973), p. 22}

Table 15. Estimated potential evapotranspiration at Franklin Lake playa using the technique of Linacre (1969, as in Jensen, 1973, p. 71) for temperature data for Boulder City, Nevada, for 1982.

$\left[{ }^{\circ} \mathrm{C}\right.$, degrees Celsius; $\mathrm{km} / \mathrm{h}$, kilometer per hour; ly/d, langley per day; $\mathrm{cm} / \mathrm{d}$, centimeters per day; in./mo, inches per month; --, missing data; source, D.A. Soule, National Weather Service, Nuclear Support Office, written commun., 1985]

\begin{tabular}{|c|c|c|c|c|c|c|c|}
\hline \multirow[t]{2}{*}{ Month } & \multicolumn{2}{|c|}{$\begin{array}{l}\text { Average monthly } \\
\text { temperature }\left({ }^{\circ} \mathrm{C}\right)\end{array}$} & \multirow{2}{*}{$\begin{array}{c}\begin{array}{r}\text { Wind } \\
\text { speed }\end{array} \\
(\mathrm{km} / \mathrm{h})\end{array}$} & \multirow{2}{*}{$\begin{array}{l}\text { Solar } \\
\text { radia- } \\
\text { tion } \\
(1 y / d)\end{array}$} & \multirow{2}{*}{$\begin{array}{l}\text { Potential } \\
\text { evapotrans- } \\
\text { piration } \\
(\mathrm{cm} / \mathrm{d})\end{array}$} & \multicolumn{2}{|c|}{$\begin{array}{c}\text { Pan } \\
\text { evaporation } \\
\end{array}$} \\
\hline & maximum & minimum & & & & (in./mo) & $(\mathrm{cm} / \mathrm{d})$ \\
\hline January & 11.1 & 1.2 & 71.7 & 345 & 0.34 & 3.48 & 0.29 \\
\hline February & 15.1 & 4.2 & 38.4 & 496 & .46 & 3.92 & .36 \\
\hline March & 17.8 & 5.2 & 101.8 & 568 & .61 & 6.14 & .50 \\
\hline April & 24.3 & 7.2 & 95.0 & 700 & .81 & 9.98 & .82 \\
\hline May & 28.1 & 11.7 & 81.3 & 742 & .89 & 13.00 & 1.07 \\
\hline June & 31.4 & 14.2 & 72.0 & 800 & 1.00 & 14.78 & 1.21 \\
\hline July & 32.7 & 18.0 & 53.2 & 761 & .96 & 14.45 & 1.18 \\
\hline August & 33.4 & 18.7 & 46.3 & 697 & .89 & 12.62 & 1.03 \\
\hline September & 29.2 & 14.6 & 54.0 & 603 & .72 & 9.10 & .75 \\
\hline October & 21.8 & 7.3 & 54.5 & 474 & .51 & 6.85 & .56 \\
\hline November & 14.8 & 3.0 & 52.0 & 380 & .37 & 3.82 & .31 \\
\hline \multirow[t]{2}{*}{ December } & 11.9 & 0.6 & 55.5 & 313 & .30 & -- & -- \\
\hline & & & & Average & 0.68 & & \\
\hline
\end{tabular}


Table 16. Estimated potential evapotranspiration at Franklin Lake playa using the technique of Linacre (1969, as in Jensen, 1973, p. 71) for temperature data for Boulder City, Nevada, for 1983.

$\left[{ }^{\circ} \mathrm{C}\right.$, degrees Celsius; $\mathrm{km} / \mathrm{h}$, kilometer per hour; ly/d, langley per day; $\mathrm{cm} / \mathrm{d}$, centimeters per day; in./mo, inches per month; --, missing data; source, D.A. Soule, National Weather Service, Nuclear Support Office, written commun., 1985]

\begin{tabular}{|c|c|c|c|c|c|c|c|}
\hline \multirow[t]{2}{*}{ Month } & \multicolumn{2}{|c|}{$\begin{array}{l}\text { Average monthly } \\
\text { temperature }\left({ }^{\circ} \mathrm{C}\right)\end{array}$} & \multirow{2}{*}{$\begin{array}{l}\text { Wind } \\
\text { speed }\end{array}$} & \multirow{2}{*}{$\begin{array}{c}\text { Solar } \\
\text { radia- } \\
\text { tion } \\
(1 y / d)\end{array}$} & \multirow{2}{*}{$\begin{array}{l}\text { Potential } \\
\text { evapotrans- } \\
\text { piration } \\
(\mathrm{cm} / \mathrm{d})\end{array}$} & \multicolumn{2}{|c|}{$\begin{array}{l}\text { Pan } \\
\text { evaporation }\end{array}$} \\
\hline & maximum & minimum & & & & (in./mo) & $(\mathrm{cm} / \mathrm{d})$ \\
\hline January & -- & -- & -- & 345 & $\left({ }^{1}\right)$ & -- & -- \\
\hline February & 14.4 & 4.4 & 43.4 & 496 & 0.46 & 3.39 & 0.28 \\
\hline March & 20.1 & 6.1 & 71.5 & 568 & .60 & 6.06 & .50 \\
\hline April & 23.7 & 5.4 & 114.5 & 700 & .83 & 8.56 & .70 \\
\hline May & 29.8 & 10.6 & 97.4 & 742 & .94 & 13.87 & 1.14 \\
\hline June & 32.1 & 14.2 & 79.4 & 800 & 1.02 & 16.94 & 1.39 \\
\hline July & 33.9 & 16.2 & 88.3 & 761 & 1.03 & 17.45 & 1.43 \\
\hline August & 34.0 & 18.8 & 43.0 & 697 & .89 & 10.01 & .82 \\
\hline September & 31.7 & 17.0 & 55.8 & 603 & .76 & 10.49 & .86 \\
\hline October & 24.8 & 10.9 & 42.5 & 474 & .53 & 6.80 & .56 \\
\hline November & 16.3 & 5.6 & 87.4 & 380 & .41 & 5.27 & .43 \\
\hline December & 12.5 & 2.1 & 48.6 & 213 & .22 & 3.02 & .25 \\
\hline & & & & Average: & 0.68 & & \\
\hline
\end{tabular}

${ }^{1}$ Missing value assumed to be 0.30 centimeter per day.

Table 17. Estimated potential evapotranspiration at Franklin Lake playa using the technique of Linacre (1969, as in Jensen, 1973, p. 71) for temperature data for Silverpeak, Nevada, for 1983.

$\left[{ }^{\circ} \mathrm{C}\right.$, degrees Celsius; $\mathrm{km} / \mathrm{h}$, kilometer per hour; ly/d, langley per day; $\mathrm{cm} / \mathrm{d}$, centimeters per day; in./mo, inches per month; --, missing data; source, D.A. Soule, National Weather Service, Nuclear Support Office, written commun., 1985]

\begin{tabular}{|c|c|c|c|c|c|c|c|}
\hline \multirow[t]{2}{*}{ Month } & \multicolumn{2}{|c|}{$\begin{array}{l}\text { Average monthly } \\
\text { temperature }\left({ }^{\circ} \mathrm{C}\right)\end{array}$} & \multirow{2}{*}{$\begin{array}{c}\text { Wind } \\
\text { speed } \\
(\mathrm{km} / \mathrm{h})\end{array}$} & \multirow{2}{*}{$\begin{array}{l}\text { Solar } \\
\text { radia- } \\
\text { tion } \\
(1 y / d)\end{array}$} & \multirow{2}{*}{$\begin{array}{l}\text { Potential } \\
\text { evapotrans- } \\
\text { piration } \\
(\mathrm{cm} / \mathrm{d})\end{array}$} & \multicolumn{2}{|c|}{$\begin{array}{c}\text { Pan } \\
\text { evaporation } \\
\end{array}$} \\
\hline & maximum & minimum & & & & (in./mo) & $(\mathrm{cm} / \mathrm{d})$ \\
\hline January & -- & -- & -- & 345 & -- & -- & -- \\
\hline February & -- & -- & -- & 495 & -- & -- & -- \\
\hline March & 16.2 & 2.3 & 223.2 & 568 & 0.72 & -- & -- \\
\hline April & 18.2 & 2.7 & 278.6 & 700 & .94 & -- & -- \\
\hline May & 24.3 & 6.7 & 252.3 & 742 & 1.07 & 12.76 & 1.05 \\
\hline June & 29.3 & 10.4 & 86.9 & 800 & .98 & 16.59 & 1.36 \\
\hline July & 28.7 & 9.6 & 259.4 & 761 & 1.21 & 20.24 & 1.66 \\
\hline August & 27.6 & 14.0 & 182.6 & 697 & .96 & 13.22 & 1.08 \\
\hline September & 26.7 & 10.3 & 192.6 & 603 & .88 & 12.38 & 1.01 \\
\hline October & 19.5 & 5.3 & 130.7 & 474 & .58 & 6.18 & .51 \\
\hline November & 13.3 & .6 & 174.1 & 380 & .47 & -- & -- \\
\hline December & -- & -- & -- & 313 & -- & -- & -- \\
\hline
\end{tabular}


Table 18. Estimated potential evapotranspiration at Franklin Lake playa using the nomograph for shallow lake evaporation presented in Linsley and others (1975, p. 161).

$\left[{ }^{\circ} \mathrm{F}\right.$, degrees Fahrenheit; ly/day, langleys per day; dew point calculated from eqs. 2-7 of Linsley and others (1975, p. 35); mi/d, miles per day; in./d, inches per day; $\mathrm{cm} / \mathrm{d}$, centimeters per day; air temperatures are from 5-year climatological summary (June 1978-May 1983) for Mercury, Nev., in table 14 of this report; solar radiation data is from Jensen $(1973$, p. 22)]

\begin{tabular}{|c|c|c|c|c|c|c|c|}
\hline \multirow{2}{*}{ Month } & \multirow{2}{*}{$\begin{array}{l}\text { Mean } \\
\text { daily air } \\
\text { temperature } \\
\left({ }^{\circ} \mathrm{F}\right)\end{array}$} & \multirow{2}{*}{$\begin{array}{l}\text { Solar } \\
\text { radiation } \\
\text { (ly/day) }\end{array}$} & \multirow{2}{*}{$\begin{array}{l}\text { Relative } \\
\text { humidity } \\
\text { (percent) }\end{array}$} & \multirow{2}{*}{$\begin{array}{c}\text { Dew } \\
\text { point } \\
\text { (oF) }\end{array}$} & \multirow{2}{*}{$\begin{array}{l}\text { Wind } \\
\text { speed } \\
(\mathrm{mi} / \mathrm{d})\end{array}$} & \multicolumn{2}{|c|}{ PET } \\
\hline & & & & & & (in/d) & $(\mathrm{cm} / \mathrm{d})$ \\
\hline January & 43.6 & 345 & 50.8 & 36.3 & 204.0 & 0.08 & 0.20 \\
\hline February & 47.3 & 496 & 48.3 & 39.4 & 220.8 & .14 & .35 \\
\hline March & 50.1 & 568 & 48.0 & 42.2 & 225.6 & .12 & .30 \\
\hline April & 58.5 & 700 & 30.8 & 44.8 & 249.5 & .25 & .64 \\
\hline May & 67.2 & 742 & 29.8 & 53.1 & 230.4 & .29 & .74 \\
\hline June & 78.3 & 800 & 16.3 & 54.9 & 264.0 & .40 & 1.02 \\
\hline July & 84.5 & 761 & 20.0 & 64.3 & 225.6 & .38 & .97 \\
\hline August & 82.2 & 697 & 24.8 & 65.5 & 213.6 & .36 & .91 \\
\hline September & 75.2 & 603 & 27.5 & 60.0 & 206.4 & .26 & .66 \\
\hline October & 63.8 & 477 & 27.8 & 48.7 & 201.6 & .18 & .45 \\
\hline November & 50.7 & 380 & 36.8 & 39.2 & 196.8 & .16 & .41 \\
\hline \multirow[t]{2}{*}{ December } & 45.0 & 313 & 42.8 & 35.4 & 184.8 & .08 & .20 \\
\hline & & & & & Average: & 0.22 & 0.57 \\
\hline
\end{tabular}

Linacre (1969) developed a method for estimating PET based on the relation:

$$
\operatorname{PET}=\frac{\left[0.167 R+0.014 u\left(T_{\max }-T_{\min }\right)\right]}{\left[22.0-0.15\left(T_{\max }+T_{\min }\right)\right]},
$$

where

PET is potential evapotranspiration, in millimeters per day;

$R$ is mean net solar radiation, in langleys per day;

$u$ is mean wind speed, 1 meter above land surface, in kilometers per day;

$T_{\max }$ is the mean monthly maximum temperature, in degrees Celsius; and

$T_{\min }$ is the mean monthly minimum temperature, in degrees Celsius.

Results obtained by using this method to estimate PET at Franklin Lake playa are listed in tables 14-17. Estimates were made for those periods that had measurements of the required variables available for stations at Mercury, Boulder City, and Silverpeak, Nev. Average annual PET was calculated for station data from Mercury and Boulder City to be 1.02 and $0.65 \mathrm{~cm} / \mathrm{d}$.
The final method used to estimate PET from meteorological data is presented in Linsley and others (1975, p. 161). This technique was developed by the U.S. Weather Service; it is used to estimate PET, using the relations developed by Penman (1948). This method requires mean daily air-temperature, solar-radiation, relative-humidity, dew-point, and wind-speed data. Results from application of this method are listed in table 18; average annual potential evapotranspiration was estimated to be $0.57 \mathrm{~cm} / \mathrm{d}$.

\section{Results and Analysis}

Results for all of the above potential evapotranspiration estimation techniques are shown in figure 28 . These rates have a wide range, spanning from about 0.1 to $0.5 \mathrm{~cm} / \mathrm{d}$ for January and 0.5 to $1.7 \mathrm{~cm} / \mathrm{d}$ for July. Because these estimates are for "potential" evapotranspiration under agricultural conditions, all of them probably indicate values larger than those that actually would be measured onsite. In addition, bare-soil conditions typically exhibit less evapo-transpiration than equivalent locations with well-watered vegetation.

Additional empirical relations were developed to estimate actual evapotranspiration at Franklin Lake 
Table 19. Measured and predicted evapotranspiration at Franklin Lake playa using average monthly temperature and average monthly solar-radiation data.

[ET, evapotranspiration; ${ }^{\circ} \mathrm{C}$, degrees Celsius; ly/d, langleys per day; $\mathrm{cm} / \mathrm{d}$, centimeters per day]

\begin{tabular}{lcccccc}
\hline Month & $\begin{array}{c}\text { Average } \\
\text { temperature } \\
\left({ }^{\circ} \mathrm{C}\right)\end{array}$ & $\begin{array}{c}\text { Average } \\
\text { solar } \\
\text { radiation } \\
(\text { ly/d) }\end{array}$ & $\begin{array}{c}\text { Measured ET, } \\
\text { figure 26B } \\
(\mathrm{cm} / \mathrm{d})\end{array}$ & $\begin{array}{c}\text { ET, } \\
\text { equation } \\
19 \mathrm{a} \\
(\mathrm{cm} / \mathrm{d})\end{array}$ & $\begin{array}{c}\text { ET, } \\
\text { equation } \\
19 \mathrm{~b} \\
(\mathrm{~cm} / \mathrm{d})\end{array}$ & $\begin{array}{c}\text { ET, } \\
\text { equation } \\
19 \mathrm{c} \\
(\mathrm{cm} / \mathrm{d})\end{array}$ \\
\hline January & 6.4 & 345 & 0.10 & 0.10 & 0.08 & 0.08 \\
February & 8.5 & 498 & .11 & .11 & .14 & .13 \\
March & 10.1 & 568 & .14 & .12 & .16 & .15 \\
April & 14.7 & 700 & .17 & .15 & .21 & .20 \\
May & 19.6 & 742 & .22 & .18 & .23 & .22 \\
June & 25.7 & 800 & .30 & .22 & .25 & .25 \\
July & 29.2 & 761 & .26 & .25 & .23 & .24 \\
August & 27.9 & 697 & .20 & .24 & .21 & .22 \\
September & 24.0 & 603 & .16 & .21 & .18 & .19 \\
October & 17.7 & 474 & .12 & .17 & .13 & .14 \\
November & 10.4 & 380 & .11 & .12 & .10 & .10 \\
December & 7.2 & 313 & .10 & .10 & .07 & .08 \\
\hline
\end{tabular}

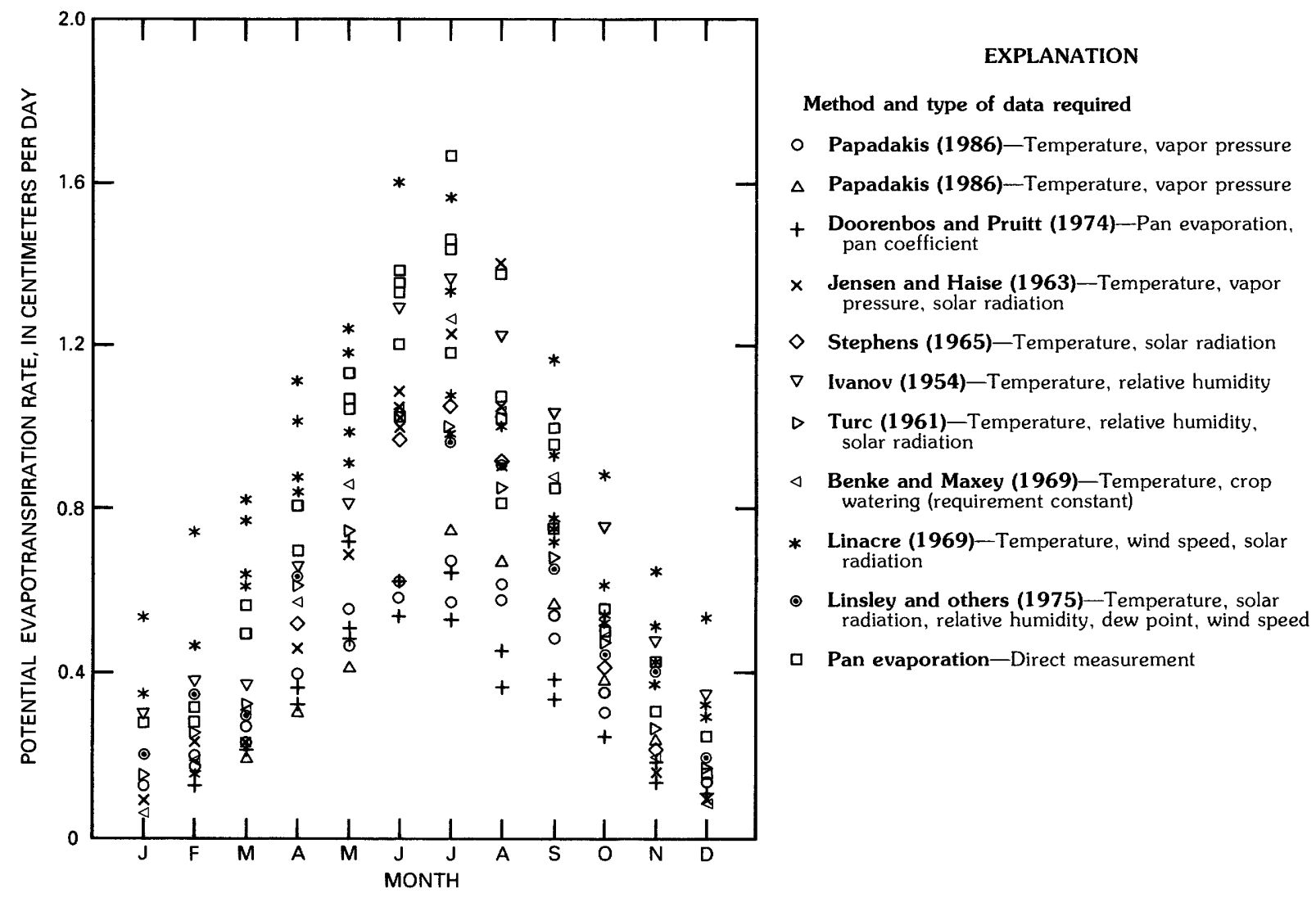

Figure 28. Summary of potential evapotranspiration estimation results. 


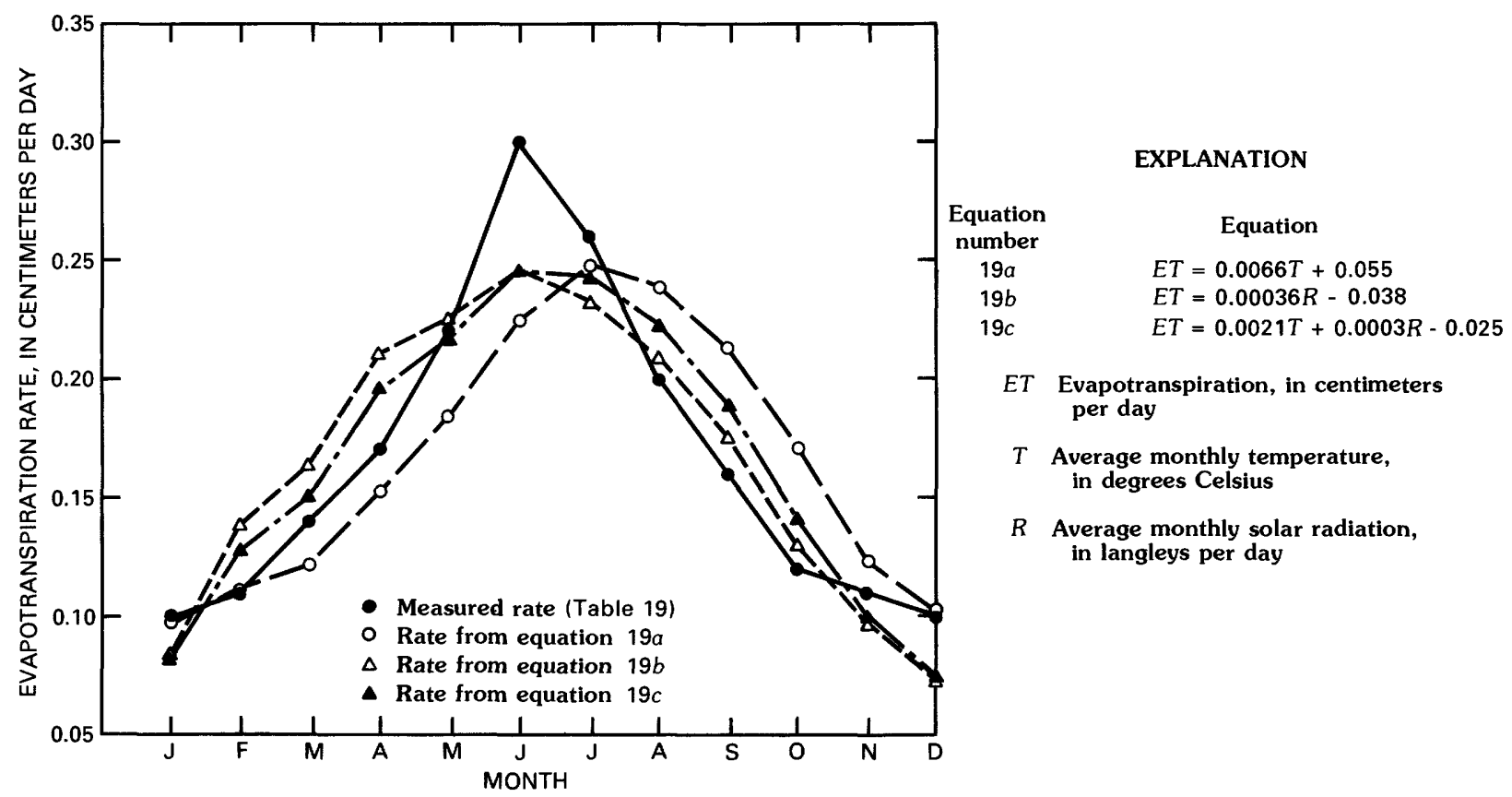

Figure 29. Evapotranspiration estimates based on energy-budget eddy-correlation technique and selected equations.

playa from air-temperature and solar-radiation data. Evapotranspiration estimates made for Franklin Lake playa based on the results of the energy-budget eddy-correlation technique (fig. 26) were correlated with average monthly temperature from table 1 in Czarnecki (1990) and monthly solar-radiation data from Jensen (1973, p. 22). A multiple-regression procedure was used to derive the following relations to estimate evapotranspiration:

$$
\begin{gathered}
E T=0.0066 T+0.055, \\
E T=0.00036 R-0.038, \\
E T=0.0021 T+0.0003 R-0.025,
\end{gathered}
$$

where

$E T$ is evapotranspiration, in centimeters per day;

$T$ is the average monthly temperature, in degrees Celsius;

and

$R$ is average monthly solar radiation, in langleys per day.

These equations represent a useful way to estimate evapotranspiration at Franklin Lake playa based on average monthly air-temperature and solar-radiation data. The estimates of evapotranspiration from the energy-budget eddy-correlation technique are compared with predicted values of evapotranspiration using equations $19 \mathrm{a}, \mathrm{b}$, and $\mathrm{c}$ in table 19 , the agreement between predicted and measured values is good (fig. 29). The correlation coefficients $\left(R^{2}\right)$ for equations $19 \mathrm{a}, \mathrm{b}$, and $\mathrm{c}$ were $0.66,0.82$, and 0.85 ; the standard errors were $0.039,0.029$, and 0.028 percent. These equations represent a useful way to estimate evapotranspiration at Franklin Lake playa based on average monthly air-temperature and solar-radiation data. Although these equations enable estimation of evapotranspiration from two relatively easily measured variables, the equations are based on average monthly air-temperature and solar-radiation data obtained at Mercury, Nev. Also, other factors, such as relative humidity, depth to the water table, water salinity, and soil-moisture characteristics, are not taken into consideration in these equations but would have an effect on the actual evapotranspiration. For these reasons, care needs to be taken when these relations are used to estimate evapotranspiration elsewhere.

\section{Moisture Content in the Unsaturated Zone}

Evapotranspiration rates conceivably may be estimated by measuring changes in soil-moisture content in the unsaturated zone. When a profile is obtained of the soil-moisture content with depth at various times, the direction of moisture movement can 
be inferred by the soil-moisture gradients, and estimates may be made of losses or gains in the moisture content from profiles obtained at different times.

Moisture contents in the unsaturated zone beneath Franklin Lake playa were determined from logging data by using a soil-moisture probe (Campbell Pacific Nuclear, Model 503 Hydroprobe). The soil-moisture probe emits neutrons that are slowed in the presence of water. Moisture content can be obtained by measuring the number of neutrons emitted and deflected back to the probe. Soil-moisture logs for wells GS-4, GS-5, GS-6, GS-15, GS-18, and GS-20 are shown in Czarnecki (1989, figs. 5A-F). These wells were constructed using 5.27 -cm-diameter ABS plastic pipe; this construction allowed insertion of the neutron probe and permitted pumping to obtain hydrochemical samples.

The soil-moisture probe was calibrated by first obtaining cores of the shallow unsaturated zone and immediately logging the core hole, using the soil-moisture probe with and without plastic casing inserted in the core hole. Moisture content of the sealed core then was measured in the laboratory by using a gravimetric procedure. In addition, soil-moisture probe calibrations were made in pipe suspended in air ( 0 percent water saturation) and in capped pipe suspended in a barrel of water (100 percent water saturation).

Soil-moisture profiles were used to identify changes in moisture content with time in the unsaturated zone, such as from cooler winter months to hot summer months. During these periods, changes in evapotranspiration may occur, and these changes might indicate differences in total moisture content in the soil-moisture-content profiles. This method was used to estimate moisture-flux rates. Differences in moisture contents for different logs for all combinations of periods are listed in Czarnecki (1990, table 16 $A-F)$. These differences, divided by time, were used to estimate moisture flux, $E$, as:

$$
E=\frac{m_{1}-m_{2}}{t_{1}-t_{2}}, t_{1}<t_{2}
$$

where

$m_{1}$ is the moisture content of the soil column in centimeters of water taken at time $t_{1}$;

and

$m_{2}$ is the moisture content measured at time $t_{2}$. The spectrum of possible differences in moisture contents, divided by the period of time between

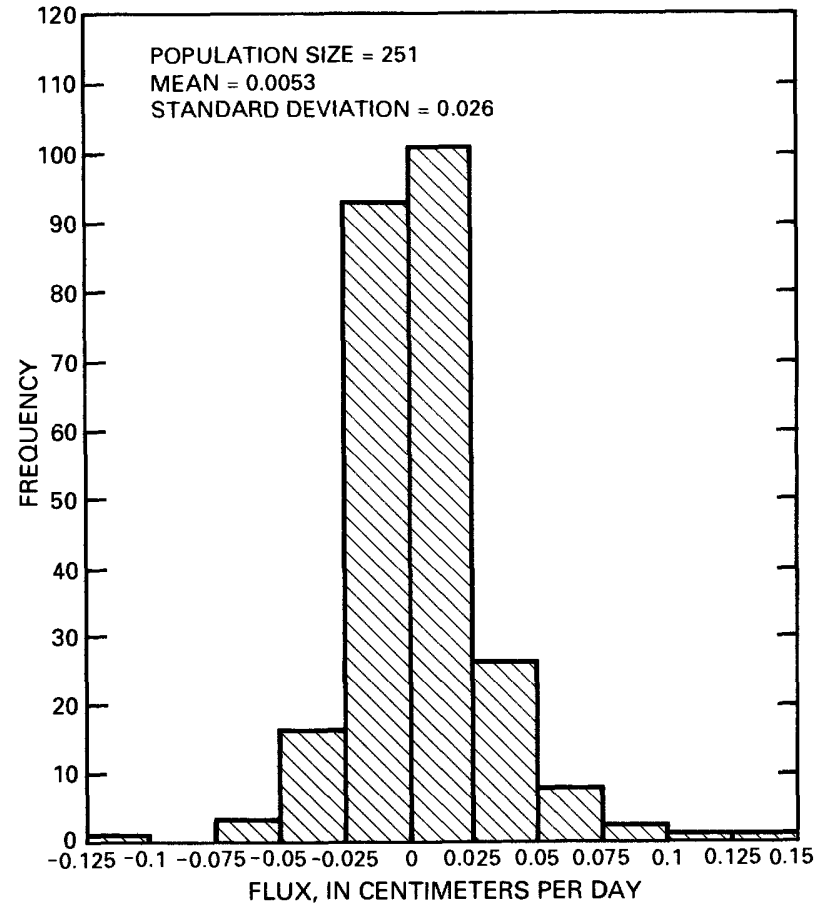

Figure 30. Distribution of fluxes estimated from changes in soil-moisture contents with time.

the times at which the profiles were obtained, is shown in Czarnecki (1990, fig. 6). A histogram for all of the fluxes is shown in figure 30; data for fluxes is listed in Czarnecki (1990, tables 16A-F).

The data (Czarnecki, 1990, tables 16A-F) show positive fluxes, indicating an increase in soil moisture with time, and negative fluxes, indicating a decrease in soil moisture with time. Although sampling was sparse, the data tend to cluster around $0.0 \mathrm{~cm} / \mathrm{d}$, indicating that static conditions may exist. However, a grouping of positive fluxes indicates that recharge conditions may occur at or near GS-20 (Czarnecki, 1990, fig. $6 F$ ); well GS-20 is located adjacent to the Amargosa River stream channel.

Comparisons of soil-moisture profiles obtained at intervals greater than 1 year probably indicate overall increases in precipitation and streamflow for the period of this study. Generally, there was less precipitation in 1983 than in 1984 and 1985. This is also supported by the hydrograph for GS-20 (Czarnecki, 1990, fig. $3 H$ ).

A limitation to this method is that, although a flux magnitude may be estimated, direction cannot be estimated only from the water content of the soil-moisture profiles. The flow direction might be determined by comparing neutron logs side by side and looking for moisture-pulse movements in the 
profile (Czarnecki, 1990, fig. 5). However, no major pulses are apparent, probably because conditions are static. Also, because the upward moisture flux toward land surface probably is near steady state throughout the year, differences in moisture content between logs probably would be small, as indicated by the small range in flux estimates.

Soil-moisture profiles are limited in applicability for estimating evapotranspiration. The greatest limitation probably is that data for the upper $30 \mathrm{~cm}$ of the soil-moisture profile are absent, resulting from the design of the soil-moisture probe. It is likely that the largest changes in soil moisture occur in the upper 30 $\mathrm{cm}$. Increases or decreases in moisture content in the unsaturated zone can result from changes in water-table position or from recharge that occurs from precipitation or runoff. In general, the neutron logs indicate a nearly steady-state moisture profile with time, particularly near land surface. All moisture-content profiles almost invariably show a decrease in moisture content from the saturated zone toward land surface resulting from an evaporative driving force. This permits the assumption that evapotranspiration results in discharge of ground water originating from the saturated zone rather than discharge of unsaturated-zone water originating from precipitation or runoff. Many of the observed changes are in the lower part of the unsaturated zone. Evaporative fluxes estimated by this technique give larger magnitudes for smaller time differences and smaller magnitudes for larger times, as would be expected if time is the flux denominator.

\section{Evapotranspiration by Phreatophytes}

Extensive studies have been done by various researchers (Lee, 1912; White, 1932; Young and Blaney, 1942; Houston, 1950; Robinson, 1958, 1965; Blaney and Hanson, 1965; and Harr and Price, 1972) to determine rates of evapotranspiration for various phreatophytes at different geographic locations in the United States. Robinson (1958) tabulated estimates of evapotranspiration for saltgrass (Distichlis stricta) grown in tanks; annual rates for California (Owens Valley and Santa Ana) ranged from 0.09 to $0.34 \mathrm{~cm} / \mathrm{d}$.

Relations between evapotranspiration and depth to the water table and evapotranspiration and average annual temperature (Robinson, 1958, fig. 7, p. 18) indicate that evapotranspiration rates increased with decreasing depths to the water table and with

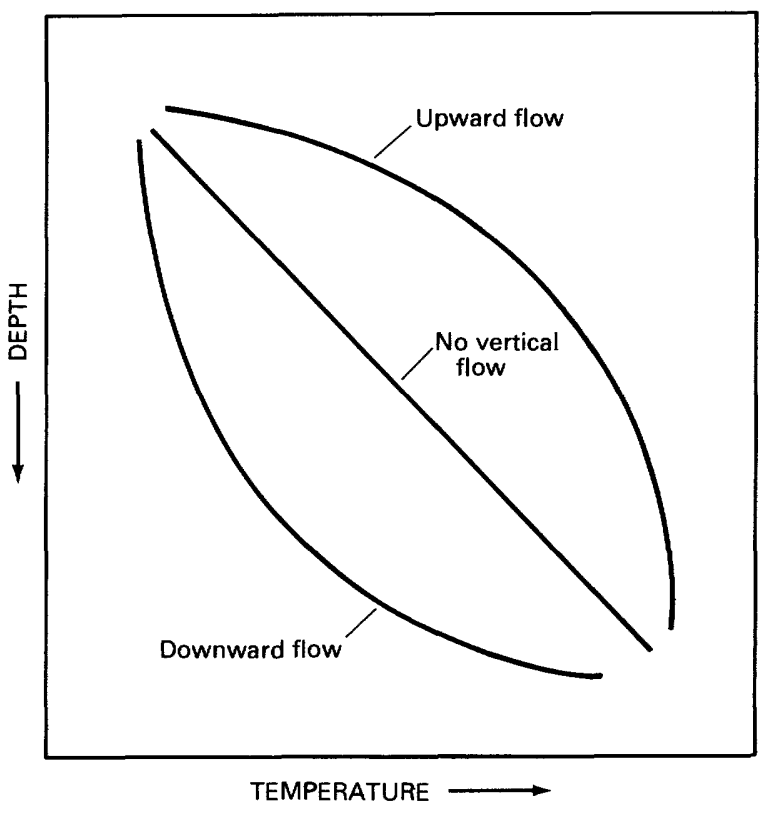

Figure 31. Idealized temperature profiles for upward, downward, and no vertical ground-water flow within the saturated zone below the zone of surface heating and cooling effects (modified from Bredehoeft and Papadopulos, 1965, fig. 2).

increased average annual temperature. Depths to the water table at the eastern margin of Franklin Lake playa range between 0.2 and $1.2 \mathrm{~m}$; these depths compare well with the range in depths to water given as 1.0 to $4.0 \mathrm{ft}$ in the tank experiment of Young and Blaney (1942, p. 44); the average annual temperature of Franklin Lake playa is approximately $62^{\circ} \mathrm{F}$, as reported by Czarnecki (1989, table 1). This temperature compares well with the average temperatures of Owens Valley $\left(68^{\circ} \mathrm{F}\right)$ and Santa Ana $\left(61^{\circ} \mathrm{F}\right)$ measured during the saltgrass-evapotranspiration experiments. Although evapotranspiration by saltgrass (Distichlis stricta) was not measured directly at the margins of Franklin Lake playa, the average annual rate probably falls within the range of 0.1 to $0.3 \mathrm{~cm} / \mathrm{d}$. Published evaporation data for seep weed (Suaeda fruticosa) and greasewood (Sarcobatus vermiculatus) were unavailable. However, evapotranspiration estimates from the eddy-correlation technique for sites with these phreatophytes were similar to evapotranspiration estimates from sites without phreatophytes.

\section{Vertical Ground-Water Velocity Estimated from Temperature Logs}

Temperature measurements at different depths in the saturated zone may be used to estimate heat flux 
and vertical ground-water velocity. This estimate of velocity then may be used as an estimate of the vertical specific discharge represented as evapotranspiration. The temperature profile of the zone of saturation may be obtained by measuring the temperature of the water column in a well at prescribed depths. Idealized temperature profiles for upward, downward, and no vertical ground-water flow within the saturated zone below the zone of surface heating and cooling effects are shown in figure 31 . This temperature profile or log then may be used to estimate heat flux through the zone of saturation. This heat flux, $q$, may be estimated (Lachenbruch and Sass, 1977) from the following expression:

$$
q=K \frac{\mathrm{d} T}{\mathrm{~d} Z}
$$

where

$K$ is the thermal conductivity of the saturatporous media, in watts per meter per degree Celsius; and

$\frac{\mathrm{d} T}{\mathrm{dZ}}$ is the temperature gradient calculated between two temperature measuring points separated by a distance, $d Z$, in degrees Celsius per meter.

In general, the vertical heat flow in the saturated zone in a homogeneous porous media is a constant if ground-water flow is strictly horizontal. When ground-water flow has a vertical component of flow, then heat may be convected in the direction of flow. By estimating the heat flux, $q$, at points along the vertical in the zone of saturation, the following expresson (Sass and Lachenbruch, 1982) may be used to estimate the velocity of the vertical-flowcomponent:

$$
\begin{gathered}
q=q_{\mathrm{o}} \mathrm{e}^{-A Z}, \\
\ln q=\ln q_{\mathrm{o}}-A Z, \\
A=\rho^{\prime} c^{\prime} V / \mathrm{K},
\end{gathered}
$$

where

$A$ is the slope of the line in equation 23 , in meters $^{-1}$;

$Z \quad$ is the depth below land surface, in meters;

$q_{\mathrm{o}}$ is the y-intercept value of heat flux, in milliwatts per meter;

$\rho^{\prime} c^{\prime} \quad$ is the thermal heat capacity of the matrix, in joules per cubic meter per degree Celsius;
$V$ is the vertical-seepage velocity, in meters per second; and

$\mathrm{K}$ is the thermal conductivity of the saturated porous media, in watts per meter per degree Celsius.

By applying linear regression analysis to heat fluxes calculated at various depths, the slope of the line, $A$, and the intercept, $q_{\mathrm{o}}$ may be obtained. $A$ typical value of $\rho^{\prime} c^{\prime}$ is $4.210^{6} \mathrm{~J} / \mathrm{m}^{3}{ }^{\circ} \mathrm{C}$ and for $\mathrm{K}$ is $1.2 \mathrm{~J} / \mathrm{m} / \mathrm{s} /{ }^{\circ} \mathrm{C}$.

Logs of the relation of water temperature to depth were obtained for several wells at Franklin Lake playa in an attempt to estimate vertical ground-water velocities from equation 24 . Logs were obtained by lowering a needle-probe thermistor connected to a logging cable down each well and recording the resistance at 0.15 -m-depth intervals. Readings were taken from a hand-held, digital ohm-meter with 4.5-digit precision. Each reading was made after the probe had remained at a given depth for exactly 10 seconds; the time of 10 seconds was considered long enough for the needle-probe thermistor to equilibrate with the surrounding water but short enough for the thermal mass of the probe to have minimal effect on the surrounding water. The equation used to convert resistances to temperatures is

$$
T=\frac{\mathrm{a}}{(\mathrm{b}+\log R)}-\mathrm{c},
$$

where

$T$ is temperature, in degrees Celsius;

$a, b$, and c are empirical coefficients;

and

$R$ is resistance measured in ohms.

Coefficients $\mathrm{a}, \mathrm{b}$, and $\mathrm{c}$ were determined for temperatures in the $15^{\circ} \mathrm{C}$ to $25^{\circ} \mathrm{C}$ range by the manufacturer.

With the ohm-meter used in these measurements, temperature measurements accurate to $\pm 0.005^{\circ} \mathrm{C}$ were possible. This accuracy was needed for measuring the slight temperature gradients associated with convected heat flux.

Temperature logs for several wells appear in figure 32. Temperature logs were obtained during March, June, and November 1985; logs are plotted on the same set of axes for each well that was logged. All temperature profiles except those for well 14 are too shallow in depth (less than $9 \mathrm{~m}$ ) for estimating vertical ground-water flow, making the near-surface effects of temperature very pronounced. However, this was not apparent for the first temperature profiles obtained in March 1985 that show concave-downward profiles. 


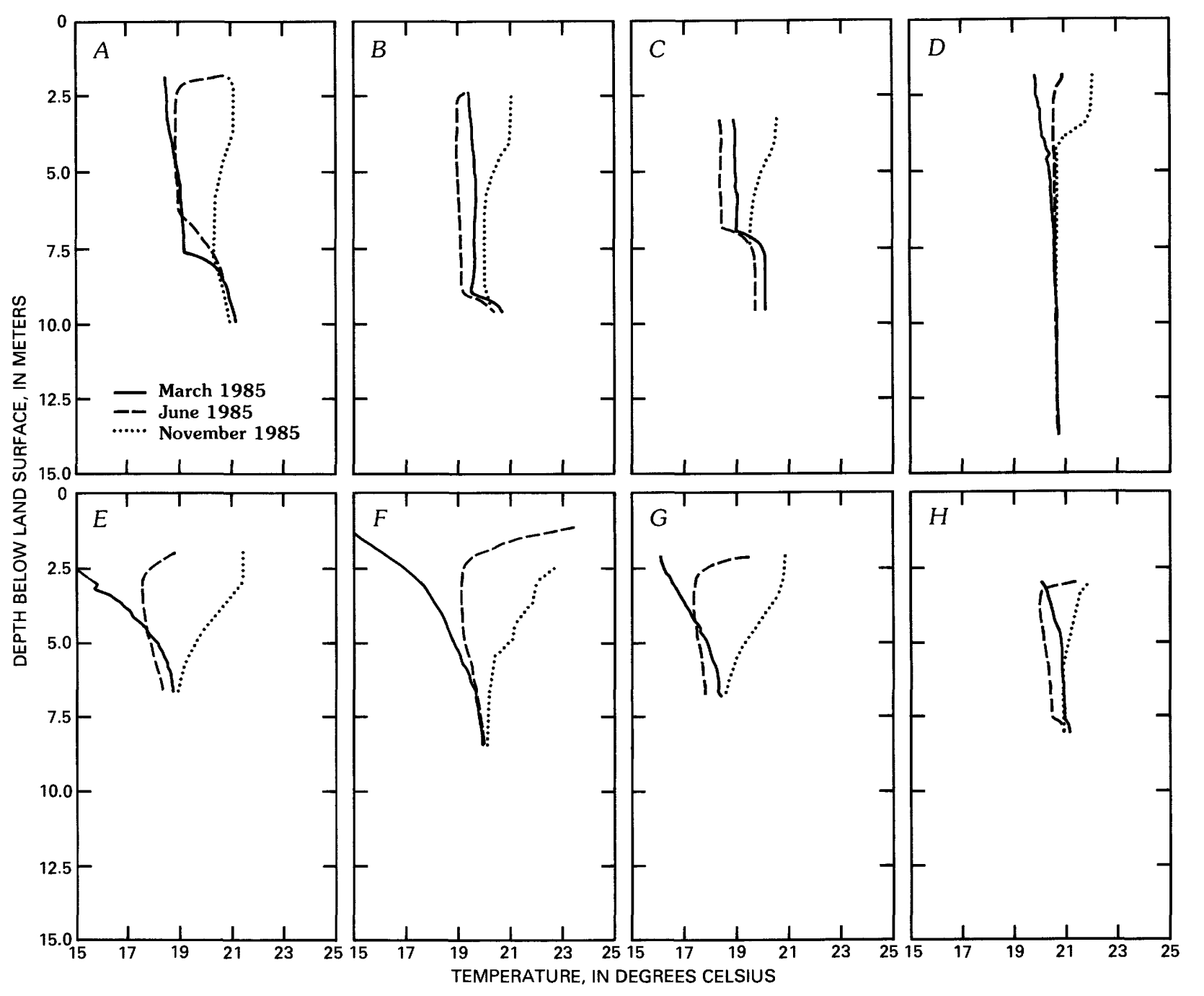

Figure 32. Temperature profiles for $A$, well $5 ; B$, well $10 ; C$, well $11 ; D$, well 14 ; $E$, well GS-5; $F$, well GS-12; $G$, well GS-15; and $H$, well GS-18.

Well 14 is the deepest of the wells on the playa, and it was the only one considered useful for estimating heat flux. However, further analyses determined that heat fluxes estimated from well 14 temperature-gradient data covered too small an interval (less than $3 \mathrm{~m}$ ) of the saturated zone to yield reliable results. Therefore, no quantitative estimates of vertical flow were made. Figure $32 D$ shows a straight line of the lowermost part of the temperature profile, indicating that little or no vertical flow occurs.

Temperature logs shown in figure 32 indicate that both recharge and discharge occur at different locations at Franklin Lake playa. Recharging conditions were observed in March 1985, when the Amargosa River flowed (fed by water from Carson Slough). Temperatures measured in wells $5,10,11$, and GS-18 indicate that ground-water recharge may have occurred at these locations; these wells are located in or near stream channel surfaces. Although flow in the Amargosa River is ephemeral, the effect of recharge may be observed several months after precipitation occurs, as indicated by the offset of June well temperatures that were cooler than March temperatures. However, this offset may be the result of the lag in response time associated with the thermal mass of the unsaturated zone. Although warmer water was observed during June in most wells nearer land surface, the temperature decreased in most wells within $2 \mathrm{~m}$ of depth below the water table.

A curious feature of temperature logs for wells $5,10,11$, and GS-18 is the increasing water temperatures in the lower part of each well (fig. 
$32 A, B, C$, and $H$ ). These increases may result from (1) recharge of cooler water; (2) formation of convection cells in the larger diameter well casings that would decrease temperature gradients; and (3) cross flow through more permeable sections of the playa sediments. The technique of Sass and Lachenbruch (1982) for analyzing heat flow is inappropriate in this instance because the temperature gradient is reversed at different locations in these wells, disputing the assumption that flow is upward.

Heat-flow analysis needs to be used with caution to obtain directions and rates of ground-water movement. Many factors in addition to the convection of heat by ground water may influence the measured temperature in the saturated zone, including changes in thermal conductivity, changes in heating or cooling at land surface, and changes in lateral movement of ground water through more permeable strata.

\section{Saturated-Zone Vertical Ground-Water Flow}

Shallow, vertical ground-water flow estimates, which may be assumed to represent evapotranspirative flux, may be made using Darcy's law:

$$
V_{z}=K_{z} \frac{\mathrm{d} h}{\mathrm{~d} z}
$$

where

$V_{z}$ is the vertical Darcy velocity, $\mathrm{L} / \mathrm{T}$;

$K_{z}$ is the vertical saturated hydraulic conductivity, L/T;

and

$\underline{\mathrm{d} h}$

$\mathrm{d} z$ is the ground-water vertical gradient, dimensionless.

If the vertical Darcy velocity is assumed to be representative of the vertical flux resulting from evapotranspiration, continuity in ground-water flow is likely through the saturated zone to the unsaturated zone up to land surface.

Vertical gradients plotted against time for a number of wells at several sites are shown in Czarnecki (1990, fig. 4). Generally, hydraulic heads increase with piezometer depth for each nest, indicating potential ground-water flow toward land surface. Because the gradient is calculated from the line of best fit through hydraulic head versus piezometer depth, the regression coefficient for each gradient (slope) calculation has been plotted also. Only gradients that have associated regression coefficients greater than
0.60 were considered to be relevant in estimating vertical Darcy velocities.

The range in positive gradient (increasing hydraulic head with depth) was about 0.1 to 0.8 . By using the best estimate of vertical hydraulic conductivity $(0.6 \mathrm{~cm} / \mathrm{d})$ derived from the determination of effective pneumatic diffusivity, the corresponding range in vertical Darcy velocities based on these gradients is 0.06 to $0.5 \mathrm{~cm} / \mathrm{d}$. This range is in good agreement with the annual range of evapotranspiration ( 0.1 to 0.3 $\mathrm{cm} / \mathrm{d}$ ) estimated using the energy-budget eddy-correlation technique.

Although estimates of vertical potentiometric gradients provide data for estimating vertical ground-water velocities corresponding to ground-water recharge or discharge rates, errors may result from any of the following: (1) Inadequate grouting or improper gravel packing around a piezometer, causing water to enter above the slotted or screened interval of the piezometer, resulting in erroneous estimates of hydraulic head; (2) use of water wells that are slotted or screened over the entire depth of the well below the water table (as is the case for wells 1, 3, 5-8, $10,11,13$, and 14) that would yield a composite hydraulic head; (3) use of hydraulic-head data from a piezometer "nest" that is, in fact, a collection of wells that may be several hundred meters apart; (4) assumption that the vertical hydraulic conductivity estimated for one site is representative of other sites, and that vertical hydraulic conductivity remains constant with depth; and (5) measurement error in measuring depths to water in piezometers. At Franklin Lake playa, conditions (2), (3), and (4) are the most likely, although all of these conditions probably were sources of error.

\section{One-Dimensional Model of Variably Saturated Ground-Water Flow}

A one-dimensional digital model of variably saturated ground-water flow was constructed using the digital-flow model of Lappala and others (1987) as an additional corroborative effort to verify evapotranspiration estimates, and as a means to examine variables affecting ground-water flow in the unsaturated zone, or the zone above the water table, as it exists at the East site at Franklin Lake playa. Reasons for selecting this site included its shallow depth to water $(125 \mathrm{~cm})$, and available porosity, moisture content, and soil-tension data. Visual inspection of core collected at the East site indicated that the soil was a uniform silty clay, free of gravel interbeds, making it easier to represent in a 


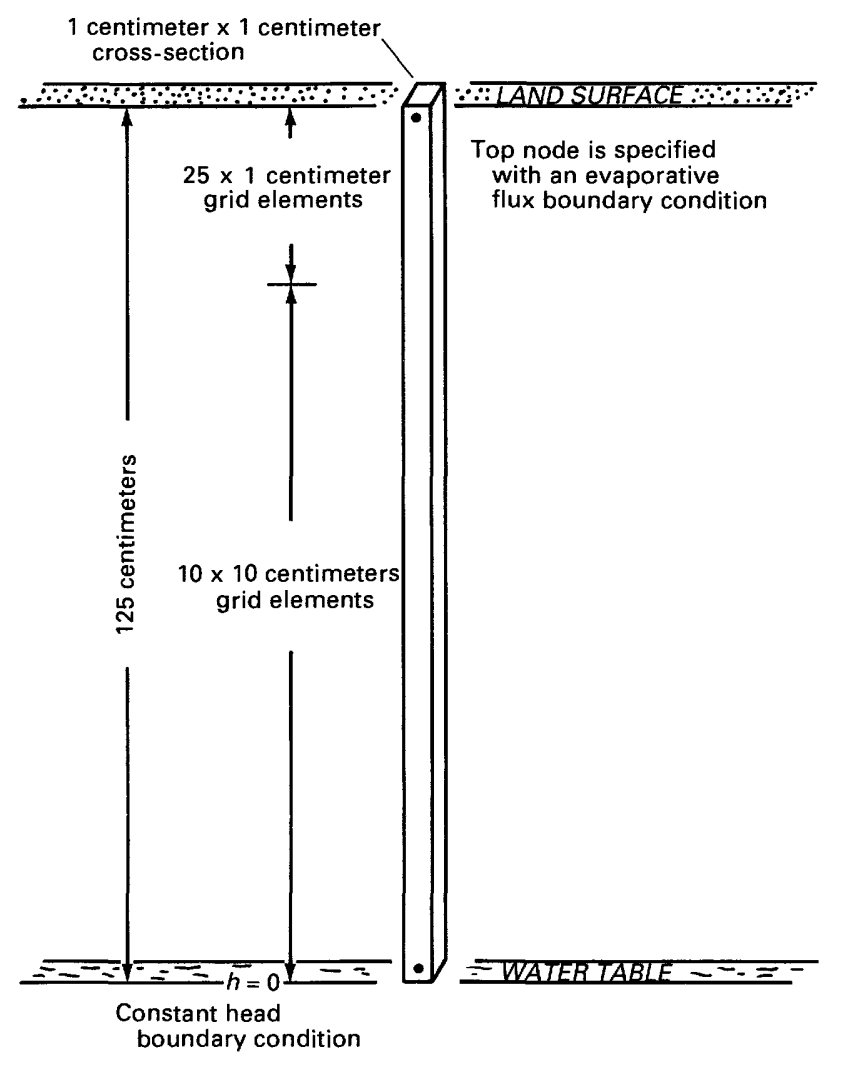

Figure 33. Model grid design and boundary conditions. A constant head of 0-0 centimeters was specified at the bottom of the column, corresponding to the water table. At the top-most cell, evaporation to the atmosphere is calculated based on variables specified in the one-dimensional model. A refined grid consisting of the top 25 elements permitted computation of the abrupt pressure drop as seen in figure $41 B$.

model by specifying uniform material properties. The governing equation solved in this model is a combination of the conservation of mass equation and Darcy's law, written as

$$
\nu \frac{\partial(\rho s \phi)}{\partial \mathrm{t}}=\int_{\overline{\mathrm{s}}} \rho K_{\mathrm{s}} K_{\mathrm{r}} \frac{\partial \mathrm{H}}{\partial n} \mathrm{~d} \overline{\mathrm{s}}+\rho q \nu,
$$

where

$v$ is the volume of an arbitrary grid block;

$\rho$ is the liquid density;

$\mathrm{s}$ is the liquid saturation;

$\phi$ is the porosity;

$t$ is the time;

$\bar{s}$ is the surface of the arbitrary volume;

$K_{\mathrm{s}}$ is the saturated hydraulic conductivity;

$K_{\mathrm{r}}$ is the relative hydraulic conductivity;

$\underline{\partial H}$ is the gradient of the total potential normal

$\partial n$ to surface $\bar{s}$; and

$\mathrm{q}$ is the volumetric source-sink term for liquid added to $(+q)$ or taken away from $(-q)$ the volume, $v$, per unit volume per unit time.

\section{Model Design}

The East site, which has a shallow water table ( $125 \mathrm{~cm}$ below land surface), was selected for simulation to minimize the length of the one-dimensional column of finite-difference grid blocks needed (fig. 33). The bottom block-centered node of the grid coincides with the water table, and a constant-head $(h=0)$ boundary condition was imposed there. At the top node, an evaporation boundary condition was imposed by specifying a large negative atmospheric potential, which allows moisture to be removed from the column under bare-soil evaporation conditions. When the top-node boundary conditions are specified in this manner, the model calculates the requisite discharge at the top node to satisfy mass-balance and hydraulic requirements.

\section{Model Variables and Sensitivity Analyses}

Variables used in this model were estimated, in part, based on measurements made at Franklin Lake playa. Where insufficient data existed, a systematic variation in a given variable (within the constraints of the physical system) was used to estimate the variable value for the model. Deviation beyond the constraints of the physical system was examined by using sensitivity analyses. Variable values used in the final simulation and used for baseline conditions in sensitivity analyses are summarized in table 20 .

Saturated hydraulic conductivity was specified on the basis, in part, of the results of the sensitivity analyses done on this variable. Specific storage, $S_{s}$ was estimated by using the relation:

$$
S_{s}=\rho g(\alpha+\phi \beta) \text {, }
$$

where

$\rho$ is the density of water; $g$ is the gravitational constant;

$\alpha$ is the compressibility of the porous media; $\phi$ is porosity;

and 
Table 20. Summary of variable values for the one-dimensional column simulation using variably saturated, two-dimensional (VS2D) finite-difference model.

[cm/d, centimeters per day; $\mathrm{cm}$, centimeters]

\begin{tabular}{lc}
\multicolumn{1}{c}{ Variable } & Value \\
\hline Saturated hydraulic conductivity & $38 \mathrm{~cm} / \mathrm{d}$ \\
Specific storage, $S_{S}$ & $4.39 \times 10^{-7}$ \\
Porosity, $\Phi$ & 0.62 \\
Bubbling pressure head, $h_{b}$ & $-9.5 \mathrm{~cm}$ of water \\
Pore size distribution exponent, $\lambda$ & 0.54 \\
Residual moisture content, $S_{r}$ & 0.18 \\
Potential evaporation rate $r$ & $-2.0 \mathrm{~cm} / \mathrm{d}$ \\
Surface impedance to evaporative flux & $0.5 \mathrm{~cm}$ \\
Total pressure potential of the atmosphere & $-1.4 \times 10^{6} \mathrm{~cm}$ \\
\hline
\end{tabular}

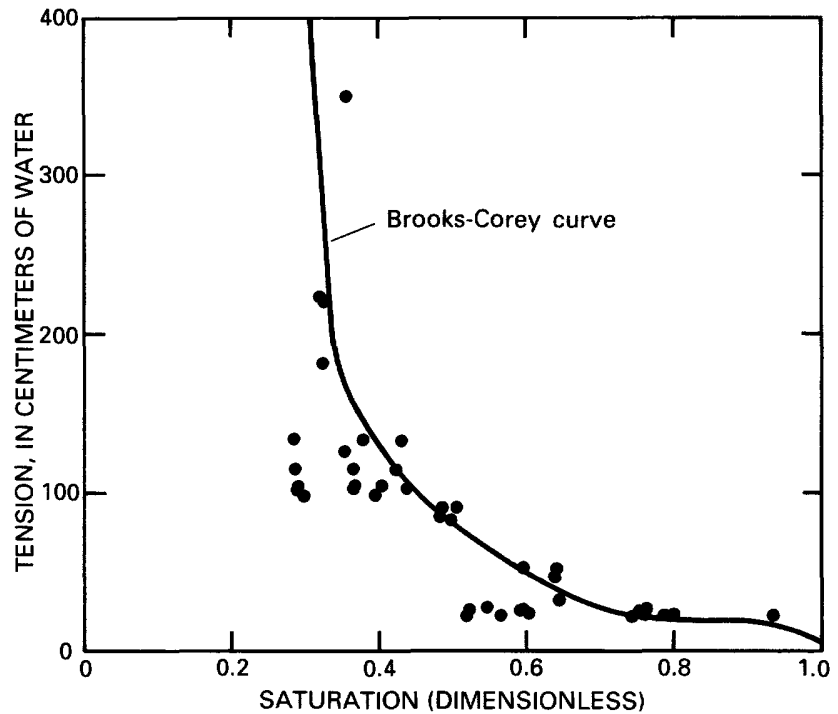

Figure 34. Relation between soil-moisture saturation and soil-moisture tension for data collected at various locations at Franklin Lake playa.

Porosity was specified on the basis of estimates from core analyses. The bubbling pressure head, pore-size distribution exponent, and residual moisture content that were specified resulted from analyses of the Brooks-Corey moisture-characteristic curves that best fit saturation and soil-moisture-tension data from Franklin Lake playa. The potential evapotranspiration rate was specified on the basis of the maximum anticipated evapotranspiration rate at Franklin Lake playa. Surface impedance to evaporative flux was specified as one-half the thickness of the top finite-difference grid block of the one-dimensional

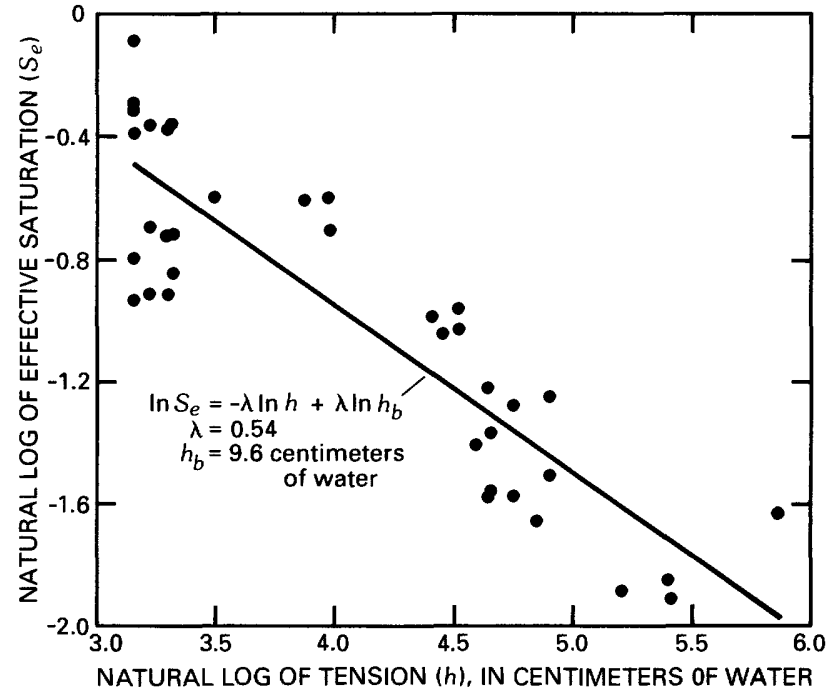

Figure 35. Relation between the natural logarithm of effective-saturation data and the natural logarithm of soil-moisture tension.

column. The total pressure potential of the atmosphere was specified on the basis of suggestions in the user's manual of the VS2D computer program (Lappala and others, 1987).

\section{Moisture-Characteristic-Curve Variables}

To simulate moisture movement through the unsaturated zone, soil-moisture-characteristic variables that relate soil-moisture content and tension need to be specified. For this particular model, the Brooks-Corey relation (Brooks and Corey, 1964) was selected to represent the soil-moisture tension relation. 
Table 21. Moisture-characteristic-curve parameters at different values of residual-moisture content.

$\left[S_{\mathrm{r}}\right.$, residual moisture content, dimensionless; $\lambda$, pore-size distribution exponent, dimensionless; $h_{\mathrm{b}}$ bubbling pressure, in centimeters of water; $\mathrm{R}^{2}$, correlation coefficient, dimensionless]

\begin{tabular}{cccc}
\hline$s_{\mathrm{r}}$ & $\lambda$ & $h_{\mathrm{b}}$ & $\mathrm{R}^{2}$ \\
\hline 0.0 & 0.315 & 7.04 & 0.77 \\
.05 & .396 & 8.38 & .71 \\
.10 & .397 & 7.97 & .77 \\
.15 & .458 & 8.64 & .77 \\
.20 & .545 & 9.58 & .78 \\
.25 & .683 & 11.0 & .78 \\
\hline
\end{tabular}

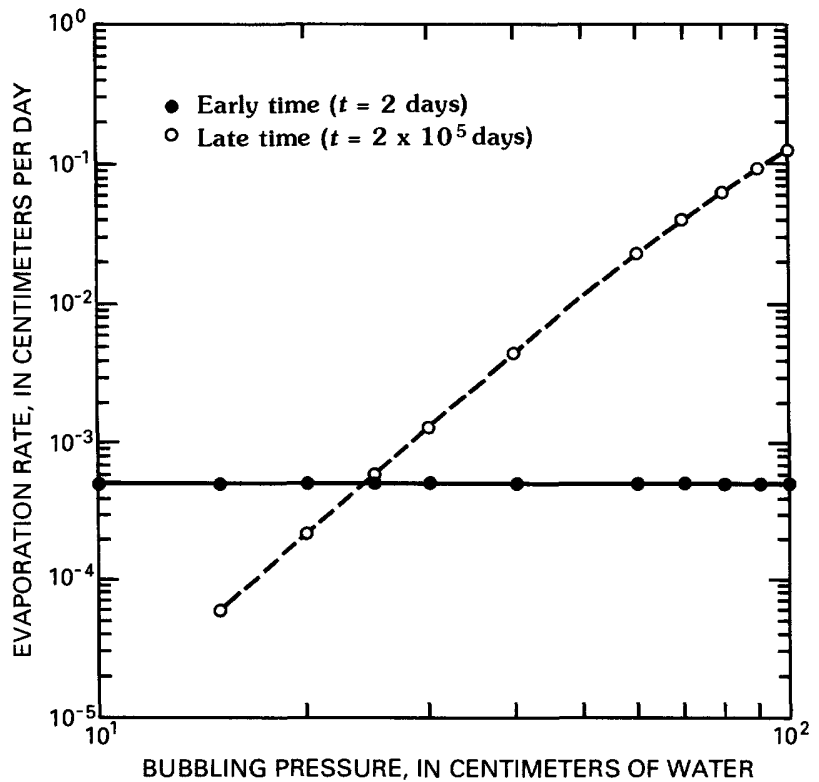

Figure 36. Sensitivity analysis of the effect of varying model value of the bubbling-pressure head, $h_{\mathrm{b}}$.

This relation may be written as:

$$
S_{\mathrm{e}}=\left(\frac{h}{h_{\mathrm{b}}}\right)^{-\lambda}
$$

where

$S_{\mathrm{e}}$ is the measured onsite saturation; or $\frac{S-S_{\mathrm{r}}}{1-S_{\mathrm{r}}}$;

$S_{\mathrm{r}}$ is the residual saturation;

$h$ is the measured onsite tension or negtive tive-pressure head;

$h_{\mathrm{b}}$ is the bubbling-pressure head;

and

$\lambda$ is the exponent related to pore size distribution.

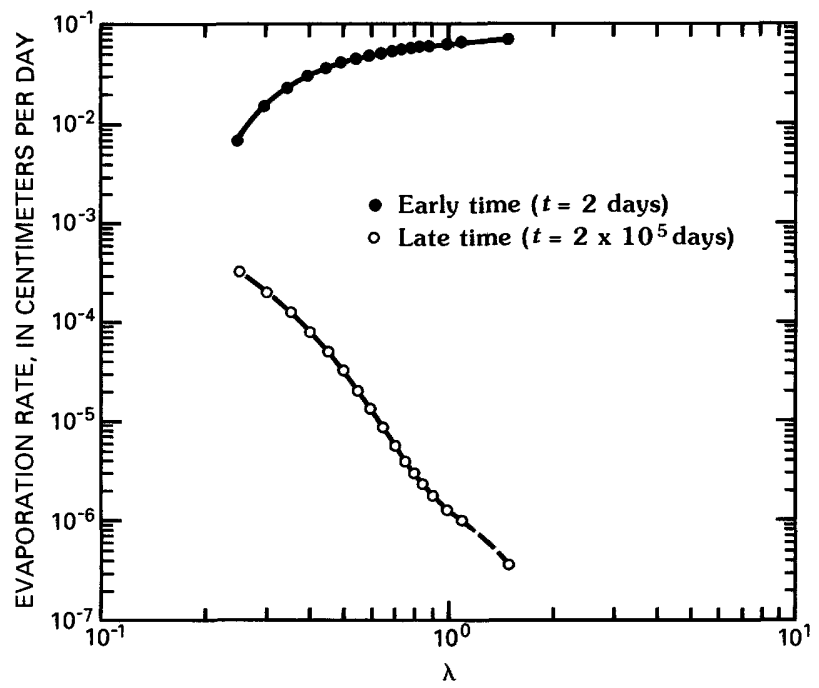

Figure 37. Sensitivity analysis of the effect of varying model value of the pore-size distribution exponent, $\lambda$.

The onsite data used to estimate the BrooksCorey variables consisted of soil-moisture tensions measured using tensiometers and soil-moisture contents measured using data from boreholes adjacent to the tensiometer nests. A porosity of 0.62 was assumed on the basis of core analyses. The relation between soil-moisture saturation and soil-moisture tension is shown in figure 34 . The data shown in figure 34 were collected from tensiometers at the East, North, and South-Central study sites for different periods throughout the year. Results from laboratory desaturation experiments done on cores obtained from Franklin Lake playa were deemed unacceptable for calculating Brooks-Corey variables because of failures of the desaturation equipment to adequately desaturate the core and because of other experimental and mechanical problems. More reliable data that probably better represent ambient conditions was obtained from onsite measurements of soil-moisture tensions using tensiometers and from soil-moisture contents from soil-moisture profiles. These data have been transformed in figure 35 to show the logarithmic relation:

$$
\ln S_{\mathrm{e}}=-\lambda \ln h+\lambda \ln h_{\mathrm{b}},
$$

where

$S_{\mathrm{r}}$ (used in calculating the effective saturation $S_{\mathrm{e}}$ ) was set to 0.20 ;

$-\lambda$ is the slope of the line of best fit;

and

$\lambda \ln h_{\mathrm{b}}$ is the $\mathrm{Y}$ intercept. 


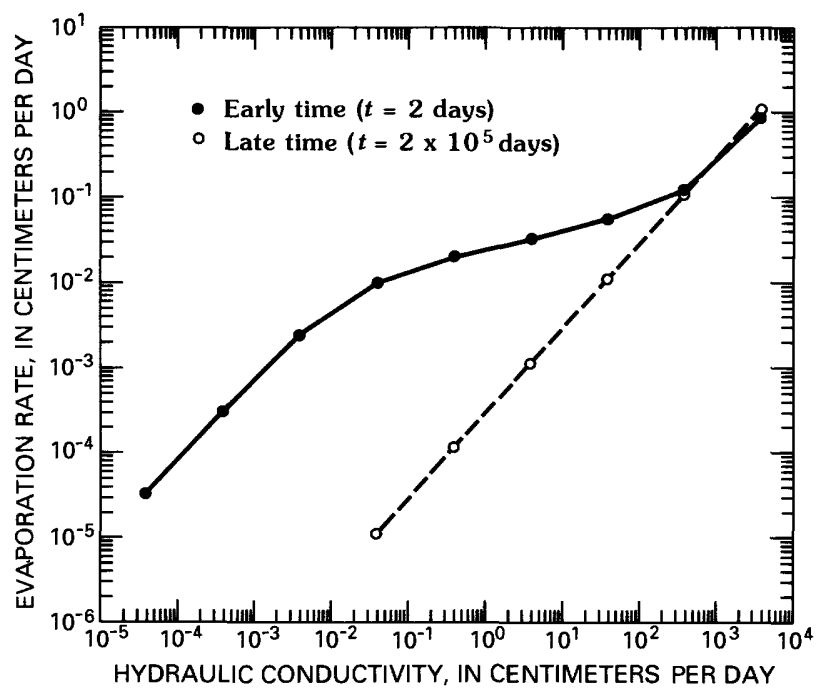

Figure 38. Sensitivity analysis of the effect of varying model value of saturated hydraulic conductivity.

Various values of $S_{\mathrm{r}}$ and the regression coefficient, $R^{2}$, which is a measure of optimum fit for the linearized equation (eq. 30 ) of the moisture-characteristic curve, are listed in table 21.

The effect of varying the model variable of bubbling-pressure head, $h_{\mathrm{b}}$, on the resultant estimate of evaporation is shown in figure 36 . The bubblingpressure or air-entry pressure is a small negative pressure that causes desaturation when applied to a saturated soil column. When the magnitude of the bubbling-pressure head is increased, evaporation is increased because more water is available for evaporation at the topmost model node. This would support the concept that evaporation is retarded less in fine-textured soils than in coarse-textured soils. The difference between the early-time and late-time curves in figure 36 is probably the result of the response time needed within the simulated soil column before simulated evaporation is affected by changes in the bubbling-pressure head. The sensitivity of the model estimate of evaporation was the largest to changes in bubbling-pressure head of all model variables.

Mualem (1976, p. 515) listed values of $\lambda$ for various materials; these values ranged from 0.19 for clay to 11.67 for sand. $\lambda$ was varied to test this wide range of potential values on the model-calculated evaporation rate; the results are shown in figure 37. The early-time nonsteady results show an increasing evaporation rate with increasing values of $\lambda$; late-time ( $2 \times 10^{5}$ days) results show just the opposite. The reasons for this difference are not known.

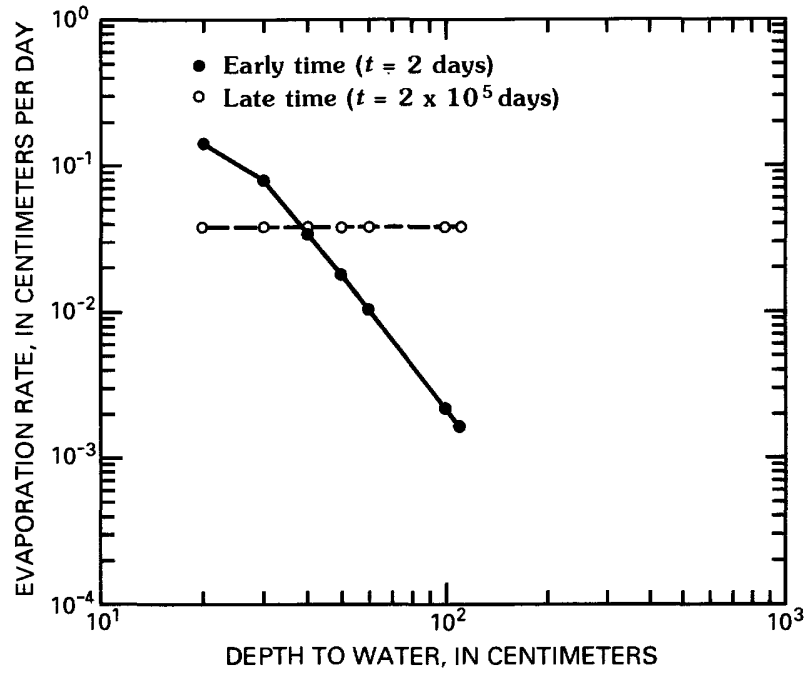

Figure 39. Sensitivity analysis of the effect of varying model value of depth to the water table.

\section{Saturated Hydraulic Conductivity}

An initial value for saturated hydraulic conductivity in the vertical dimension was specified from laboratory estimates of saturated hydraulic conductivity obtained from falling-head permeameter tests. When the model produced very small estimates of evaporation at the top node, sensitivity analyses were done by varying only the value of hydraulic conductivity to test the effect of this variable on estimates of evaporative flux. Results of varying saturated hydraulic conductivity on the model-calculated evaporation rate are shown in figure 38 . The early-time curve (at 2 days into the simulation) indicates a significantly larger evaporation rate for equivalent values of hydraulic conductivity than the late-time $\left(2 \times 10^{5}\right.$ days) curve. This rate was probably a result of large moisture contents in the upper part of the column. The two curves coincide at larger values of hydraulic conductivity. The late-time curve produced results consistent with Darcy's law; that is, larger hydraulic-conductivity values resulted in larger fluxes, if other factors were equal.

\section{Depth to Water Table}

The boundary condition at the bottom node (125 cm below land surface) was initially set as a constanthead ( $h=0$ ) boundary condition corresponding to the location of the water table. This boundary condition was moved up the one-dimensional column to examine the effect of water-table position on 


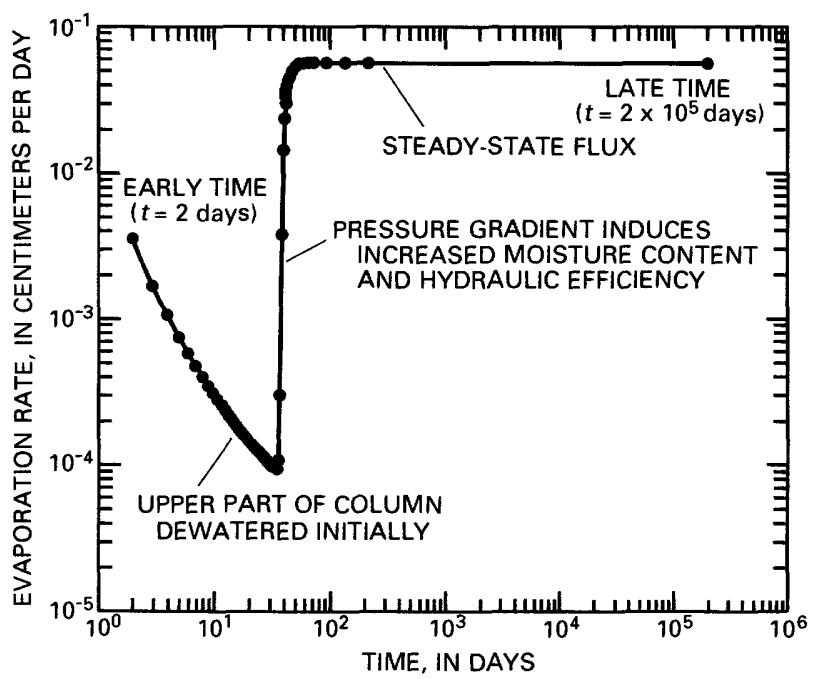

Figure 40. Changes in model-calculated evaporation rate through time.

evaporation rate. A linear relation at early time is shown in figure 39; this relation is consistent with Darcy's law; flux is related linearly to the inverse of the length over which the gradient is calculated. At late time, however, no change was observed, indicating that the model is insensitive to the position of this shallow water table, where the soil-moisture content is nearly uniform with depth, except for the topmost $10 \mathrm{~cm}$ of the column. A sufficiently large depth to the water table exists where evaporation as calculated by the model would decrease; however, this depth is greater than the length of the column $(125 \mathrm{~cm})$ used in these simulations and therefore was not simulated.

\section{Other Model Variables}

Other model variables were varied over a considerable range to test the sensitivity of the model-calculated evaporation rate to these changes. These variables included (1) initial saturation; (2) the total pressure potential of the atmosphere, $h_{\mathrm{a}} ;$ (3) porosity; (4) specific storage; (5) an upward-pressure head applied at the bottommost node; (6) surface resistance to evaporative flux; and (7) potential evapotranspiration rate. Results from these sensitivity analyses are shown in figures 43-49 in the "Supplemental Data" section at the end of this report. Variations in all these variables had negligible effect on the model-calculated evaporation rate at late time $\left(2 \times 10^{5}\right.$ days $)$.

The sensitivity analyses discussed previously are not completely rigorous. For instance, the combi-

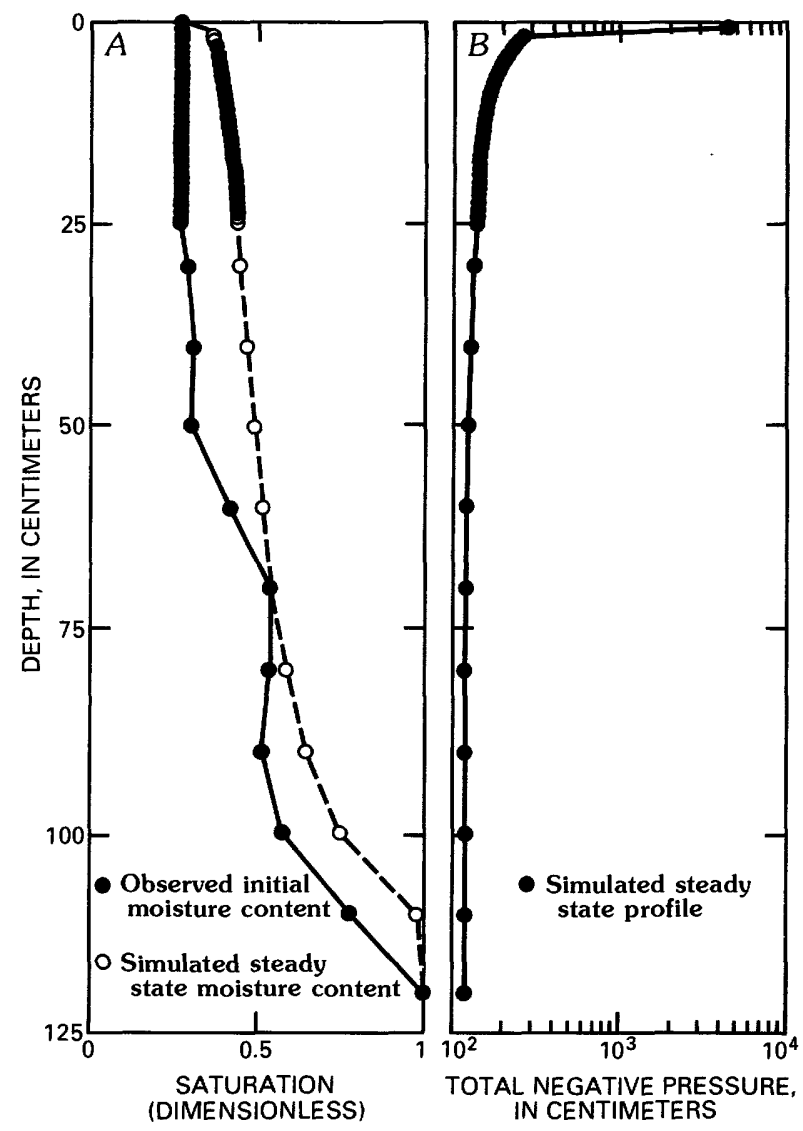

Figure 41. Model results of $A$, saturation profile; and $B$, total negative pressure head. Initial moisture content is shown as a comparison to the final results.

nation of a larger hydraulic conductivity with any other variable may have resulted in a nonhorizontal curve (figs. 43-49 in the "Supplemental Data" Section at the end of this report) because the effects from changes in a given variable were limited by another variable. This possibility was not examined, however, because of the myriad of combinations that were possible. An alternate to the style of sensitivity analyses presented here might be the application of dimensional analysis theory, which would decrease the total number of variables to be analyzed.

\section{Model-Calculated Evaporative Flux Results}

The final model consisted of variables adjusted per sensitivity-analyses results and available data; these values are listed in table 20 . The change in evaporation rate through time is shown in figure 40 . This figure suggests that moisture is being depleted in the uppermost node, as water moves up the column, increasing the hydraulic efficiency. The result 
is a rapid breakthrough of the induced-pressure pulse leading to steady-state conditions. Mass-balance error typically was three to four orders of magnitude smaller than the largest flux for any given time step.

Initial and final moisture contents versus depth are shown in figure $41 A$. Negative pressure-head profile at steady state is shown in figure $41 B$. The initial pressure head was set uniformly to zero at the start of the simulation. Moisture content increased about 50 percent over initial values. The final steady-state pressure profile shows a very large gradient at land surface, resulting from the very dry conditions there, as well as from the relatively large moisture retention $\left(S_{\mathrm{r}}=0.2\right)$ that was specified. This large gradient is required to push the water vapor to the evaporation node. The steady-state evaporative flux is about 0.06 $\mathrm{cm} / \mathrm{d}$ (fig. 40).

\section{SUMMARY AND CONCLUSIONS}

Franklin Lake playa is one of the principal discharge areas of the ground-water flow system that includes Yucca Mountain, Nevada, the potential site of a high-level nuclear-waste repository. This playa may be characterized as a "bypass playa," where part of the ground water discharges from the playa and part moves downgradient to discharge at lower topographic elevations elsewhere. Horizontal ground-water-potential gradients range from 0.002 to 0.005 (fig. 10), in contrast to the much larger upward vertical gradients that range from 0.1 to 0.8 (Czarnecki, 1990, fig. 4). Ground water occurs very near land surface, with depths to ground water less than $3 \mathrm{~m}$. Piezometers installed on the northern end of the playa had water levels $2.27 \mathrm{~m}$ above land surface, indicating the potential for ground-water discharge. Salt pan and soft, puffy, porous surfaces distributed across the playa and the presence of phreatophytes are further evidences of ground-water discharge.

Estimated transmissivity and hydraulic-conductivity values range over nine orders of magnitude depending on the technique used to estimate them. Sediments underlying the playa consist chiefly of siltand clay-sized sediments with widely interspersed gravel lenses, particularly under the Carson Slough and Amargosa River stream channels. This heterogeneity in sediment size affects local values of transmissivity and hydraulic conductivity. Estimates of vertical saturated hydraulic conductivity were made by analyzing saturated core and by determining the effective pneumatic diffusivity; the latter method resulted in the best estimate of ambient, vertical hydraulic conductivity $(0.006 \mathrm{~m} / \mathrm{d})$.

Of the techniques used to estimate evapotranspiration rates at Franklin Lake playa, the most reasonable and representative estimates are believed to come from the energy-budget eddy-correlation technique. This technique also is one of the easiest to implement. The average evapotranspiration rate estimated by this technique was $0.16 \mathrm{~cm} / \mathrm{d}$; applying this value over the area of the playa $\left(14.2 \mathrm{~km}^{2}\right)$ yields an average volumetric discharge rate of $22,800 \mathrm{~m}^{3} / \mathrm{d}$. The annual average volumetric discharge specified in the model of Czarnecki and Waddell (1984) was $35,600 \mathrm{~m}^{3} / \mathrm{d}$, but the area over which this flux was specified $\left(33 \mathrm{~km}^{2}\right)$ extended beyond the area of Franklin Lake playa where discharge is believed to occur. This volumetric discharge corresponds to an average annual evapotranspiration rate of $0.11 \mathrm{~cm} / \mathrm{d}$ and compares well with estimates presented here. The one-dimensional, finite-difference model gave a lower estimate $(0.06$ $\mathrm{cm} / \mathrm{d}$ ) of evaporation than the energy-balance eddy-correlation technique. Difficulties in estimating the vertical saturated hydraulic conductivity can affect this technique seriously, and they also can affect the use of Darcy's law for estimating flow in the saturated zone to estimate vertical Darcy velocity. Although not performed at Franklin Lake playa, measurements of evapotranspiration made at climatically similar Owens Valley and at Santa Ana, Calif., by Robinson (1958), using weighing lysimeters, essentially were identical to minimum and maximum rates estimated by the energy-budget eddy-correlation technique at Franklin Lake playa. Direct use of neutron logs and temperature logs gave inconclusive estimates of evapotranspiration. Meteorological empirical relations used to estimate potential evapotranspiration overestimated evapotranspiration by 100 to 150 percent compared to the energy-budget eddy-correlation method. The summarized results obtained from each of these techniques are listed in table 22.

Additional refinements in measurement of ET may be possible using additional techniques, such as direct-eddy correlation, the Bowen ratio, weighing lysimeters, or remote sensing. Efforts to refine 
Table 22. Summary of evapotranspiration estimates from all techniques used.

\begin{tabular}{lc} 
Technique & $\begin{array}{c}\text { Evapotranspiration } \\
\text { estimate } \\
\text { (centimeters per day) }\end{array}$ \\
\hline Energy-balance eddy correlation & 0.1 to 0.3 \\
$\begin{array}{l}\text { Empirical potential evapotranspiration relations: } \\
\quad \text { Lower range (January) } \\
\text { Upper range (July) }\end{array}$ & 0.1 to 0.5 \\
$\begin{array}{l}\text { Temporal changes in soil-moisture } \\
\text { content in the unsaturated zone }\end{array}$ & 0.5 to 1.7 \\
$\begin{array}{l}\text { Evapotranspiration by phreatophytes } \\
\text { (Robinson, 1958) }\end{array}$ & $\begin{array}{c}\text { Inconclusive } \\
\text { Temperature profiles }\end{array}$ \\
$\begin{array}{l}\text { Saturated-zone vertical gradients } \\
\text { One-dimensional finite-difference model }\end{array}$ & 0.07 to 0.34 \\
\hline
\end{tabular}

hydraulic-conductivity estimates may result in a similar wide range of values because of local heterogeneities from site to site. Techniques involving measurement of air permeability in the unsaturated zone, infiltration rates, or barometric efficiency may provide a means to diminish the range of values. Isotope hydrochemistry also may be a tool for estimating the quantity of evaporation required to produce observed isotopic composition of water in the saturated or unsaturated zone.

The rate of evapotranspiration of ground water from the saturated zone is a function of many variables: (1) phreatophyte type and density; (2) depth to the water table; (3) ground-water salinity; (4) soil-moisture characteristics; and (5) climatic factors. Of these, depth to the water table probably has a greater effect on evapotranspiration rate than the other variables. Although most of the discharge from the ground-water-flow system that includes Franklin Lake playa probably is from the playa surface, additional discharge probably occurs at upgradient areas north of Franklin Lake playa. To estimate this additional discharge, a more detailed definition of depths to the water table in these areas would be needed, as would a determination of the upgradient areas where upward vertical gradients in the upper part of the saturated zone are present or absent. The latter could be accomplished using a series of piezometer nests.

Only a general relation between depth to the water table and resultant evapotranspiration exists for this region. No systematic relation was obtained for data from the multiple sites and measurements at Franklin Lake playa; no significant change in estimated evapotranspiration was observed for a given time at sites that have differences in depths to the water table of as much as $3 \mathrm{~m}$. To observe significant changes in rates of evapotranspiration, differences in depths to the water table of $5 \mathrm{~m}$ or more between sites may be required, if all else is equal. Equivalent conditions (phreatophyte density and type, soil-moisture characteristics, and climatic factors) at various locations may be difficult to find to make valid comparisons. Undoubtedly, locations exist in the Amargosa Desert where the water table is sufficiently deep, such that evapotranspiration is negligible. That depth may be about $15 \mathrm{~m}$. Construction of piezometer and tensiometer nests in upgradient areas could provide confirmative vertical-gradient data to show the presence or absence of evapotranspiration of water from the saturated zone, as could detailed mapping of phreatophytes in these areas. 


\section{REFERENCES CITED}

Beatley, J.C., 1976, Vascular plants of the Nevada Test Site and central-southern Nevada--Ecologic and geographic distributions: Los Angeles, California University NSLaboratory of Nuclear Medicine and Radiation Biology, $316 \mathrm{p}$.

Behnke, J.J., and Maxey, G.B., 1969, An empirical method for estimating monthly potential evapotranspiration in Nevada: Journal of Hydrology, v. 8, no. 4, p. 418-430.

Blaney, H.F., and Hanson, E.G., 1965, Consumptive use and water requirements in New Mexico: Santa Fe, New Mexico State Engineer Technical Report 32, 82 p.

Bouwer, Herman, 1978, Groundwater hydrology: New York, McGraw-Hill, 480 p.

Bredehoeft, J.D., and Papadopulos, I.S., 1965, Rates of vertical groundwater movement estimated from the earth's thermal profile: Water Resources Research, v. 1, no. 2, p. 325-328.

Brooks, R.H., and Corey, A.T., 1964, Hydraulic properties of porous media: Fort Collins, Colorado State University Hydrology Paper 3, 27 p.

Brutsaert, W.H., 1982, Evaporation into the atmosphere-Theory, history, and applications: Boston, D. Reidel, 299 p.

Calzia, J.P., Crowley, J.A., Dockter, R.D., Simoni, T.R., and Server, G.T., 1979, Leasable mineral resources of the California Desert Conservation Area: U.S. Geological Survey Administrative Report, 53 p., appendix II A-L.

Campbell, G.S., 1977, An introduction to environmental biophysics: New York, Springer-Verlag, 159 p.

Claassen, H.C., 1985, Sources and mechanisms of recharge for ground water in the west-central Amargosa Desert, Nevada-A geochemical interpretation: U.S. Geological Survey Professional Paper 712-F, 31 p.

Cooper, H.H., Jr., Bredehoeft, J.D., and Papadopulos, I.S., 1967, Response of a finite-diameter well to an instantaneous change of water: Water Resources Research, v. 3 , no. 1, p. 263-269.

Czarnecki, J.B., 1985, Simulated effects of increased recharge on the ground-water flow system of Yucca Mountain and vicinity, Nevada-California: U.S. Geological Survey Water-Resources Investigations Report 84-4344, 33 p.

1990 , Geohydrologic and evapotranspiration data from Franklin Lake Playa, Inyo County, California: U.S. Geological Survey Open-File Report 89-595, $38 \mathrm{p}$.

Czarnecki, J.B., and Waddell, R.K., 1984, Finite-element simulation of ground-water flow in the vicinity of Yucca Mountain, Nevada-California: U.S. Geological Sur- vey Water-Resources Investigations Report 84-4349, $38 \mathrm{p}$.

Doorenbos, J. and Pruitt, W.O., 1974, Guidelines for prediction of crop water requirements: Rome, Food and Agriculture Organization of the United Nations, Irrigation and Drainage Paper No. 4, 179 p.

Driscoll, F.G., ed., 1986, Groundwater and wells, 2nd ed.: St. Paul, Minn., Johnson Division, 1089 p.

Eakin, T.E., Maxey, G.B., Robinson, T.W., Fredericks, J.C., and Loeltz, O.J., 1951, Contributions to the hydrology of eastern Nevada: Nevada Department of Conservation and Natural Resources Water Resources Bulletin 12 , p. 14-16.

Fritschen, L.J., 1965, Accuracy of evapotranspiration determinations by the Bowen-ratio methods: International Association of Scientific Hydrology Bulletin, v. 2, p. 38 .

Gatewood, J.S., Robinson, T.W., Colby, B.R., Hem, J.D., and Halpenny, L.C., 1950, Use of water by bottom-land vegetation in Lower Safford Valley, Arizona: U.S. Geological Survey Water-Supply Paper 1103, 210 p.

Greenhaus, M.R., and Zablocki, C.J., 1982, A Schlumberger resistivity survey of the Amargosa Desert, southern Nevada: U.S. Geological Survey Open-File Report 82-897, $151 \mathrm{p}$.

Hagar, D.J., 1970, Geology and hydrology of Coyote Playa in Motts, W.S., ed., Geology and hydrology of selected playas in Western United States: Amherst, University of Massachusetts, p. 66-107.

Harr, R.D., and Price, K.R., 1972, Evapotranspiration from a greasewood-cheatgrass community: Water Resources Research, v. 8, no. 5, p. 1199-1203.

Houston, C.E., 1950, Consumptive use of irrigation water by crops in Nevada: Reno, University of Nevada Bulletin $185,27 \mathrm{p}$.

Hunt, C.B., Robinson, T.W., Bowles, W.A., and Washburn, A.L., 1966, Hydrologic basin-Death Valley, California: U.S. Geological Survey Professional Paper 494-B, $138 \mathrm{p}$.

Ivanov, N.N., 1954, The determination of potential evapotranspiration: Izvestiia Vsesoiuznogo Geograficheskogo Obschestva, v. 86, no. 2.

Jaeger, E.C., 1940, Desert wild flowers: Stanford, Calif., Stanford University Press, $322 \mathrm{p}$.

Jaeger, F., 1942, Ein besonderer Seentypus; die Trockenseen oder Pfannen [A peculiar type of lakes-The arid lakes or pans]: Geologie der Meere und Binnengewasser, $v$. 6 , no. 1, p. 65-103.

Jensen, M.E., ed., 1973, Consumptive use of water and irrigation water requirements: New York, American Society of Civil Engineers, 215 p. 
Jensen, M.E., and Haise, H.R., 1963, Estimating evapotranspiration from solar radiation: Journal of Irrigation and Drainage Division, American Society of Civil Engineers, v. 89, p. 15-41.

Katz, D.L., Cornell, David, Kobayashi, Riki, Poettmann, F.H., Vary, J.A., Elenbaas, J.R., Weinaug, C.F. 1959, Handbook of natural gas engineering: New York, McGraw-Hill, 802 p.

Klinkenberg, L.J., 1941, The permeability of porous media to liquids and gases, in Drilling and Production Practice: New York, American Petroleum Institute, p. 200.

Lachenbruch, A.H., and Sass, J.H., 1977, Heat flow in the United States and the thermal regime of the crust, in Heacock, J.H., ed., The Earth's crust: Washington, D.C., American Geophysical Union Geophysical Monograph 20, p. 626-675.

Langer, A.M., and Kerr, P.F., 1966, Mojave Desert playa crusts-Physical properties and mineral content: Journal of Sedimentary Petrology, v. 36, no. 2, p. 377-396.

Lappala, E.G., Healy, R.W., and Weeks, E.P., 1987, Documention of computer program VS2D to solve equations of fluid flow in variably saturated porous media: U.S. Geological Survey Open-File Report 83-4099, 197 p.

Lee, C.H., 1912, An intensive study of the water resources of a part of Owens Valley, California: U.S. Geological Survey Water-Supply Paper 294, 135 p.

Linacre, E.T., 1969, Climate and evaporation from crops: Journal of the Irrigation and Drainage Division, American Society of Civil Engineers, v. 95, p. 348-352.

Linsley, R.K., Kohler, M.A., and Paulhus, J.L.H., 1975, Hydrology for engineers: New York, McGraw-Hill, $481 \mathrm{p}$.

Motts, W.S., 1965, Hydrologic types of playas and closed valleys and some relations of hydrology to playa geology, in Neal, J.T., ed., Geology, mineralogy, and hydrology of U.S. playas: Bedford, Mass., Cambridge Research Laboratory Environmental Research Paper no. 96, p. 31-57.

Motts, W.S., ed., 1970, Geology and hydrology of selected playas in Western United States: Amherst, University of Massachusetts, $286 \mathrm{p}$.

Mualem, Y., 1976, A new model for predicting the hydraulic conductivity of unsaturated porous media: Water Resources Research, v. 12, no. 3, p. 513-522.

Munz, P.A., 1974, A flora of southern California: Berkeley, University of California Press, $1086 \mathrm{p}$.

Naff, R.L., 1973, Hydrogeology of the southern part of Amargosa Desert in Nevada: Reno, University of Nevada, Masters thesis, $207 \mathrm{p}$.

Neal, J.T., 1965a, Environmental setting and general surface characteristics of playas, in Neal, J.T., ed., Geology, mineralogy, and hydrology of U.S. playas: Bedford,
Mass., Cambridge Research Laboratory Environmental Research Paper no. 96, p. 1-29.

1965b, Airphoto characteristics of playas, in Neal, J.T., ed., Geology, mineralogy, and hydrology of U.S. playas: Bedford, Mass., Cambridge Research Laboratory Environmental Research Paper no. 96, p. 149-176.

Neal, J.T., and Motts, W.S., 1967, Recent geomorphic changes in playas of Western United States: Journal of Geology, v. 75, no. 5, p. 511-525.

Pantea, M.P., 1980, Lithology and lithium content of sediments drilled in a test hole on Alkali Flat (Franklin Lake), Inyo County, California: U.S. Geological Survey Open-File Report 80-1164, 20 p.

Papadakis, Juan, 1966, Climates of the world and their agricultural potentialities: Buenos Aires, Argentina, $174 \mathrm{p}$.

Peck, A.J., 1960, The water table as affected by atmospheric pressure: Journal of Geophysical Research, v. 65, no. 8, p. 2383-2388.

Penman, H.L., 1948, Natural evaporation from open water, bare soil, and grass: Proceedings of the Royal Society of London, Biological Sciences Series A, v. 193, p. 120-146.

Philip, J.R., 1961, The theory of heat flux meters: Journal of Geophysical Research, v. 66, no. 2, p. 571-579.

Robinson, T.W., 1958, Phreatophytes: U.S. Geological Survey Water-Supply Paper 1423, $84 \mathrm{p}$.

-1965, Water use studies utilizing evapotranspiration tanks, in Cohen, Philip and others, Water Resources of the Humboldt River Valley near Winnemuca, Nevada: U.S. Geological Survey Water-Supply Paper 1795, p. 83-91.

Rush, F.E., 1970, Regional ground-water systems in the Nevada Test Site area, Nye, Lincoln, and Clark Counties, Nevada: Nevada Department of Conservation and Natural Resources Water Resources Reconnaissance Series Report 54, p. 10-16.

Sass, J.H., and Lachenbruch, A.H., 1982, Preliminary interpretation of thermal data from the Nevada Test Site: U.S. Geological Survey Open-File Report 82-0973, 30 $\mathrm{p}$.

Snyder, C.T., 1962, A hydrologic classification of valleys in the Great Basin, Western United States: International Association of Scientific Hydrology Bulletin, v. 7, no. 3 , p. 53-59.

Stephens, J.C., 1965, Discussion of "Estimating evaporation from insolation": Journal of Hydraulics Division, American Society of Civil Engineers, v. 91, no. 5, p. 171-182.

Stone, R.O., 1956, A geologic investigation of playa lakes: Los Angeles, University of Southern California, unpublished Ph.D. dissertation, $302 \mathrm{p}$. 
Tanner, C.B., 1963, Basic instrumentation and measurements for plant environment and micrometeorology: Madison, University of Wisconsin, Soils Bulletin 6, $311 \mathrm{p}$.

Thompson, D.G., 1929, The Mojave Desert region, California-A geographic, geologic, and hydrologic reconnaissance: U.S. Geological Survey Water-Supply Paper 578, 579 p.

Thornthwaite, C.W., 1948, An approach toward a rational classification of climate: Geographical Review, v. 38, p. 55.

Turc, L., 1961, Evaluation des besoins en eau d'irrigation, evapotranspiration potentielle, formule climatique simplifice et mise a jour [Estimation of irrigation water requirements, evapotranspiration potential-A simple climatic formula evolved up to date]: Annales Agronomique, v. 12, no. 1, p. 13-49.

Turk, L.J., 1975, Diurnal fluctuations of water tables induced by atmospheric pressure changes: Journal of Hydrology, v. 26, no. 1/2, p. 1-16.

van Hylckama, T.E.A., 1968, Water-level fluctuations in evapotranspirometers, Water Resources Research, v. 4, no. 4 , p. 761-768.

Waddell, R.K., 1982, Two-dimensional, steady-state model of ground-water flow, Nevada Test Site and vicinity, Nevada-California: U.S. Geological Survey Water-Resources Investigations 82-4085, $72 \mathrm{p}$.

Walker, G.E., and Eakin, T.E., 1963, Geology and groundwater of Amargosa Desert, Nevada-California: Reno, Nevada Department of Conservation and Natural
Resources Ground-Water Resources-Reconnaissance Series Report 14, 45 p.

Weaver, H.L., and Campbell, G.S., 1985, Use of peltier coolers as soil heat flux transducers: Soil Science Society of America Journal, v. 49, no. 4, p. 1065-1067.

Weeks, E.P., 1978, Aquifer tests-The state-of-the-art in hydrology, in Invitational Well-Testing Symposium, Berkeley, Calif., 1977, Proceedings: Berkeley, Lawrence Berkeley Laboratory Report LBL-7027, p. 14-26.

1979, Barometric fluctuations in wells tapping deep unconfined aquifers: Water Resources Research, v. 15, no. 5 , p. 1167-1176.

Weeks, E.P., Weaver, H.A., Campbell, G.S., and Tanner, B.D., 1987, Water use by saltcedar and by replacement vegetation in the Pecos River floodplain between Acme and Artesia, New Mexico: U.S. Geological Survey Professional Paper 491-G, $101 \mathrm{p}$.

White, W.N., 1932, A method of estimating ground-water supplies based on discharge by plants and evaporation from soil: U.S. Geological Survey Water-Supply Paper 659-A, 105 p.

Winograd, I.J., and Thordarson, William, 1975, Hydrogeologic and hydrochemical framework, south-central Great Basin, Nevada-California, with special reference to the Nevada Test Site: U.S. Geological Survey Professional Paper 712-C, $126 \mathrm{p}$.

Young, A.A., and Blaney, H.F, 1942, Use of water by native vegetation: Sacramento, California Division of Water Resources Bulletin 50, 154 p. 
SUPPLEMENTAL DATA 

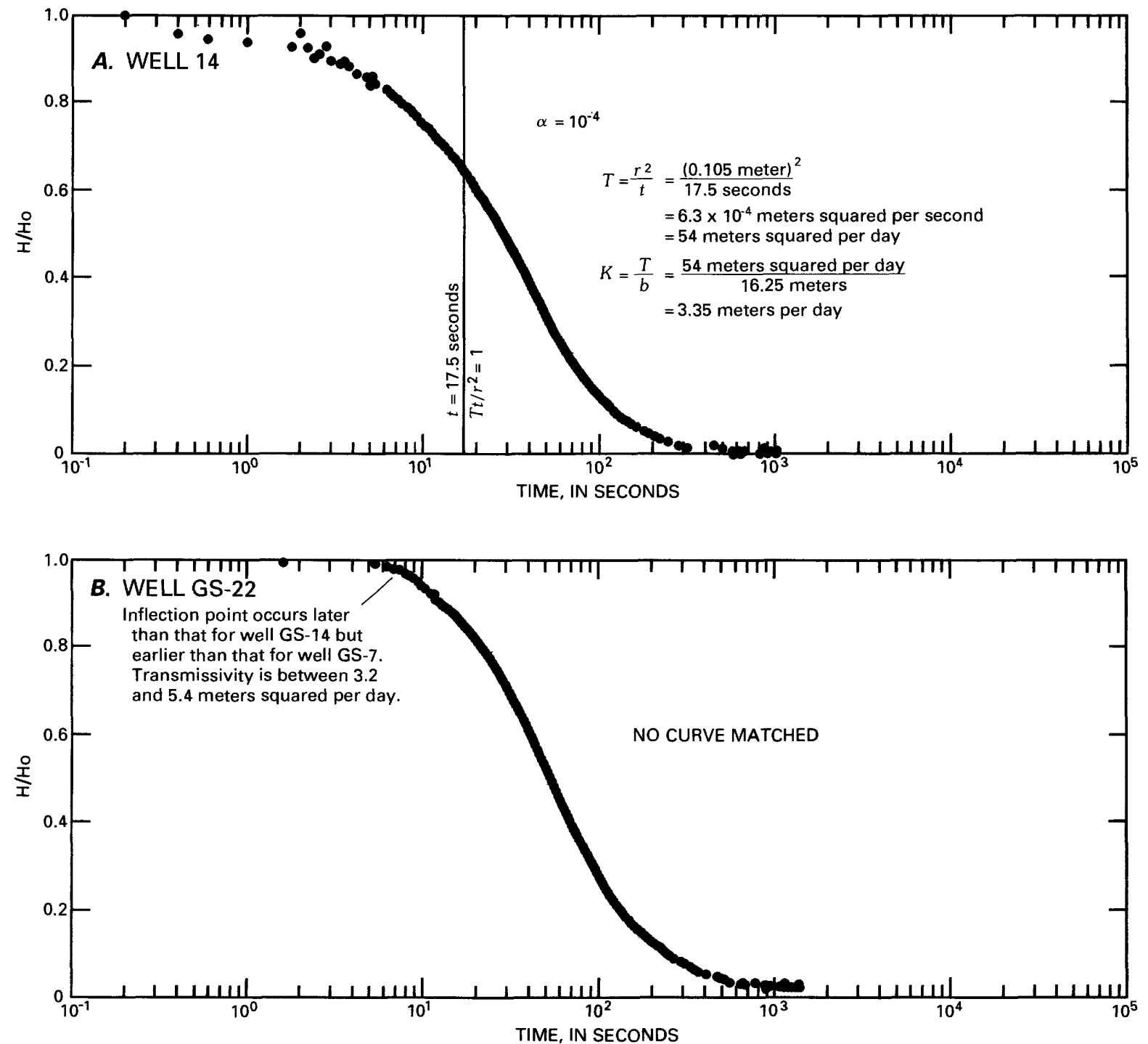

EXPLANATION

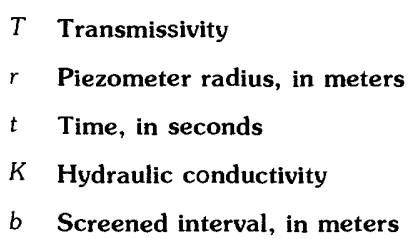

a Type-curve coefficient (dimensionless)

H/Ho Ratio millivolt-output readings transmitted from the pressure transducer to micrologger

b Screened interval, in meters

Figure 42 (above and on following pages). Slug test results for wells located at Franklin Lake playa. $A$, Slug-test results for well 14. B, Slug-test results for well GS-22. 

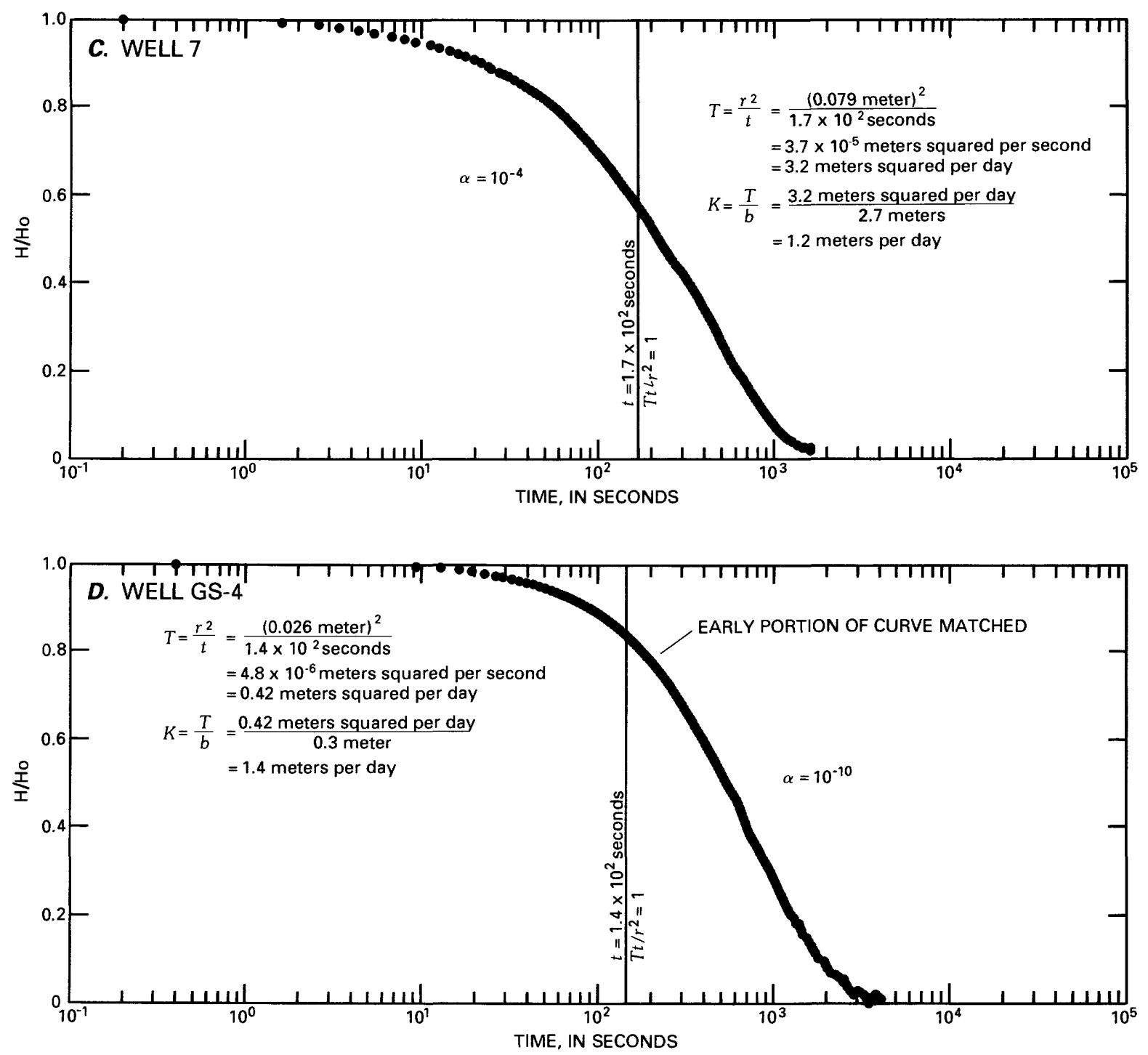

EXPLANATION

$\begin{array}{cl}T & \text { Transmissivity } \\ r & \text { Piezometer radius, in meters } \\ t & \text { Time, in seconds } \\ K & \text { Hydraulic conductivity } \\ b & \text { Screened interval, in meters }\end{array}$

a Type-curve coefficient (dimensionless)

H/Ho Ratio millivolt-output readings transmitted from

the pressure transducer to

micrologger

$C$, Slug-test results for well 7. $D$, Slug-test results for well GS-4. 

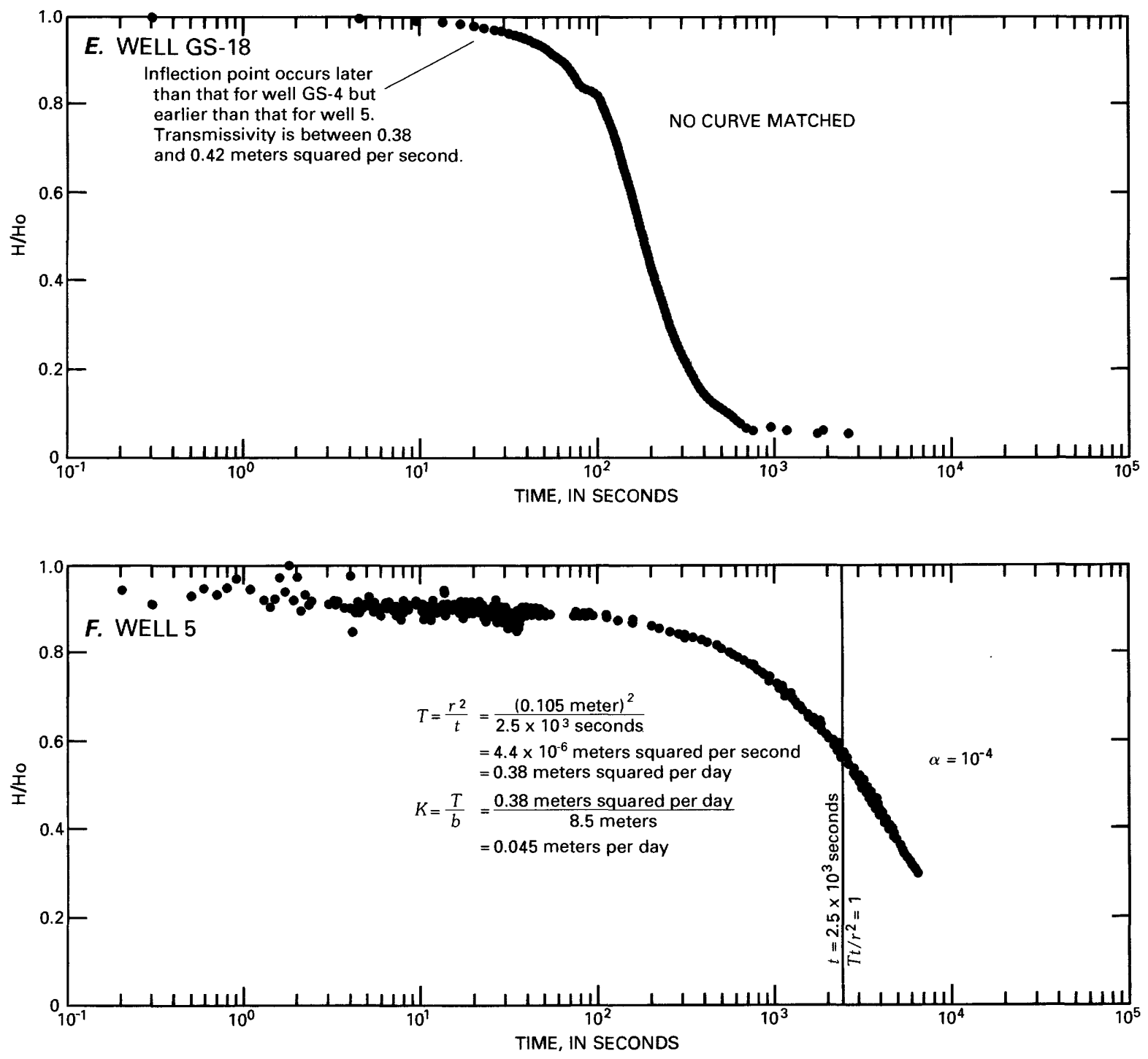

EXPLANATION

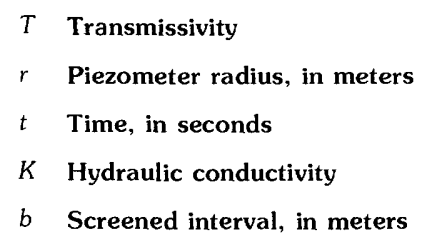

a Type-curve coefficient (dimensionless)

H/Ho Ratio millivolt-output

readings transmitted from the pressure transducer to micrologger

b Screened interval, in meters

E, Slug-test results for well GS-18. F, Slug-test results for well 5 . 

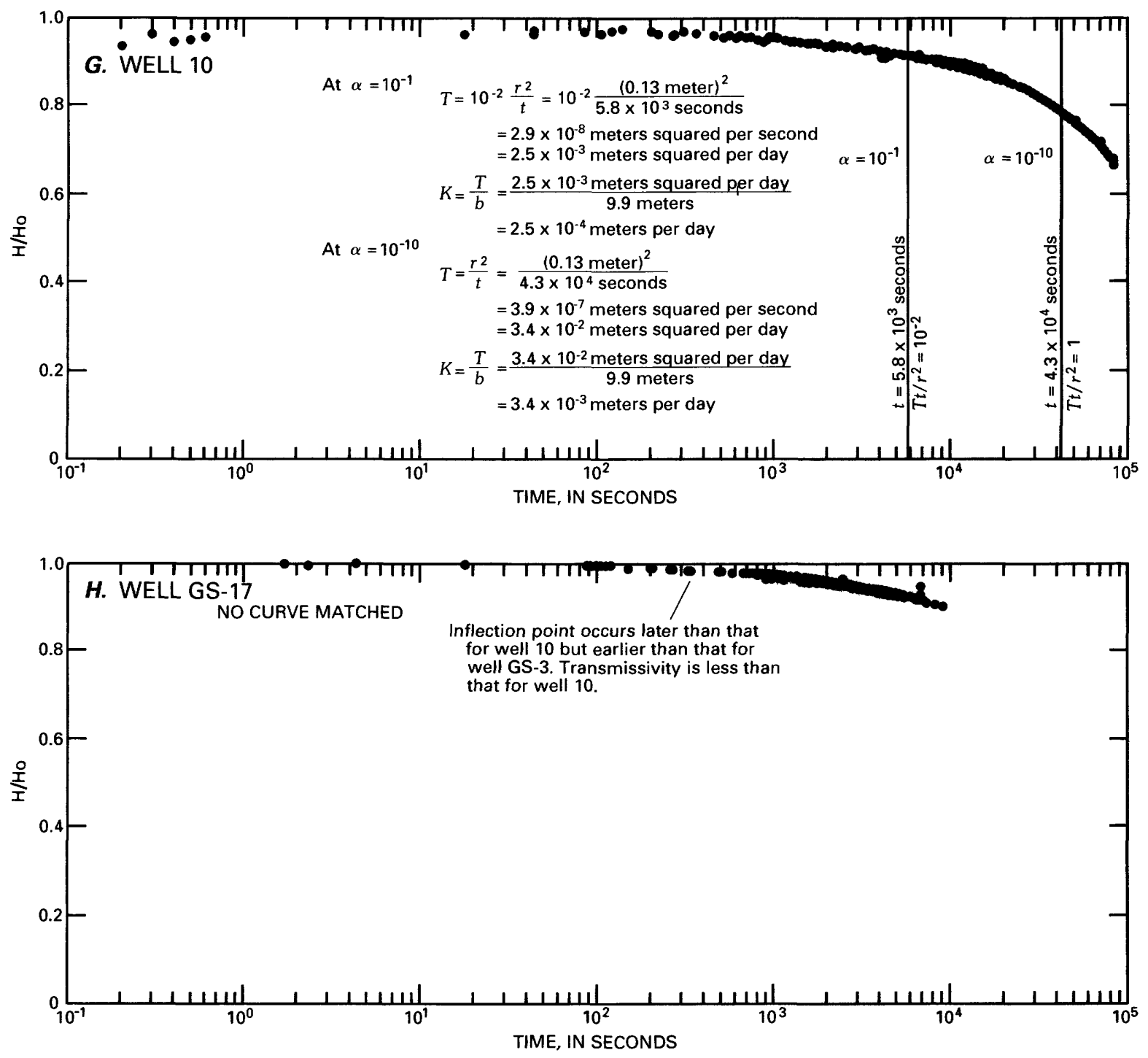

EXPLANATION

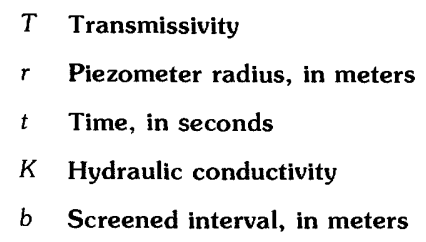

a Type-curve coefficient (dimensionless)

H/Ho Ratio millivolt-output

readings transmitted from

the pressure transducer to

micrologger

G, Slug-test results for well 10. $H$, Slug-test results for well GS-17. 

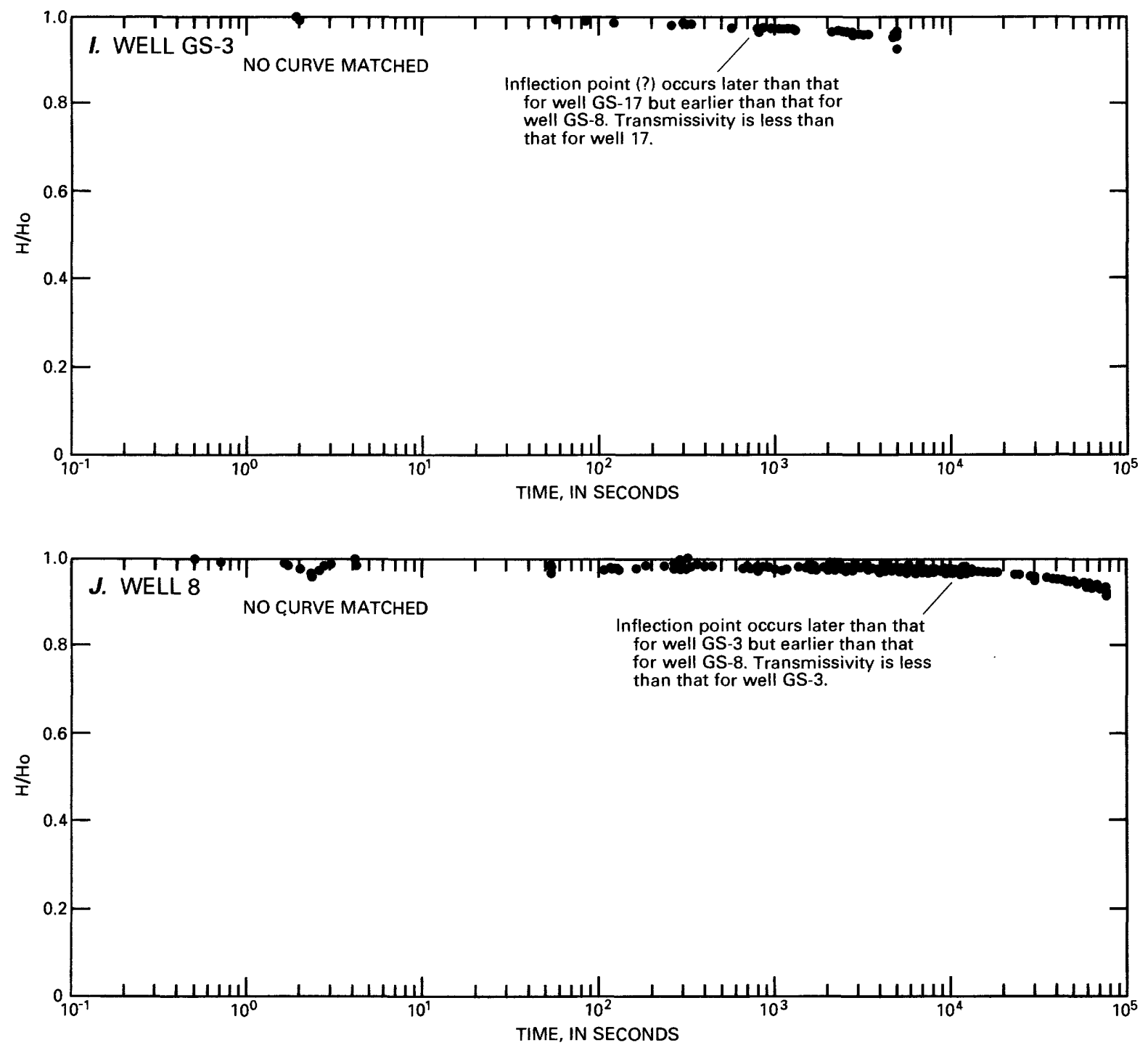

EXPLANATION

H/Ho Ratio millivolt-output

readings transmitted from

the pressure transducer to micrologger

I, Slug-test results for well GS-3. J, Slug-test results of well 8. 


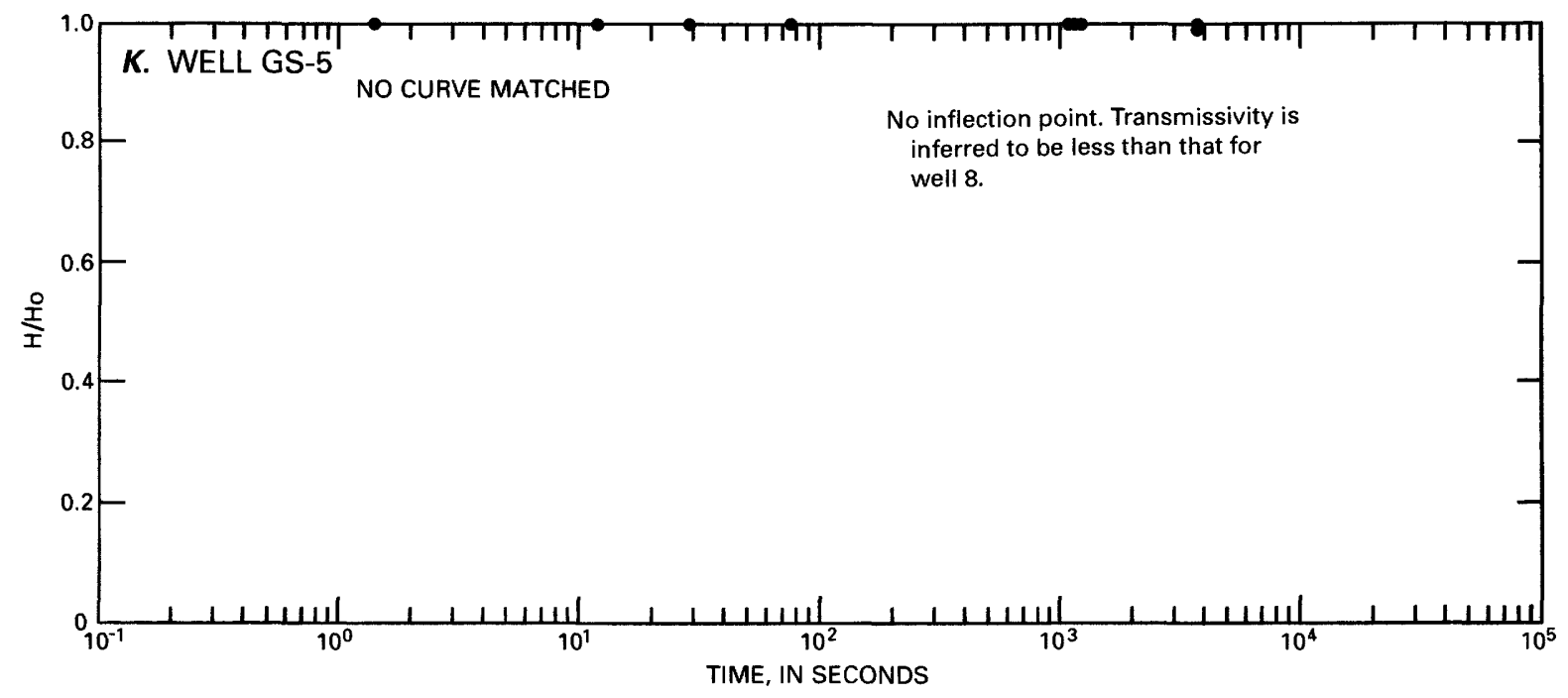

EXPLANATION

H/Ho Ratio millivolt-output

readings transmitted from

the pressure transducer to

micrologger

K, Slug-test results for well GS-5.

Table 23. Falling-head permeameter results for sample 3 from core taken from core hole EC-2, Franklin Lake playa. $\left[t_{1}\right.$, starting time; $t_{2}$, ending time; $t$, elapsed time; $H_{1}$, hydraulic head at starting time; $H_{2}$, hydraulic head at ending time; $K$, hydraulic conductivity; s, seconds; $\mathrm{cm}$, centimeters; $\mathrm{cm} / \mathrm{s}$, centimeters per second; core length,4.2 cm; core diameter, $5.2 \mathrm{~cm}$ ]

\begin{tabular}{|c|c|c|c|c|c|c|}
\hline $\begin{array}{r}t_{1} \\
(\mathrm{~s})\end{array}$ & $\begin{array}{r}t_{2} \\
(\mathrm{~s})\end{array}$ & $\begin{array}{r}t \\
(\mathrm{~s})\end{array}$ & $\begin{array}{c}H_{1} \\
(\mathrm{~cm})\end{array}$ & $\begin{array}{c}\mathrm{H}_{2} \\
(\mathrm{~cm})\end{array}$ & $\begin{array}{c}K \\
(\mathrm{~cm} / \mathrm{s})\end{array}$ & $\ln K$ \\
\hline $\begin{array}{l}0 \\
0 \\
0 \\
0\end{array}$ & $\begin{array}{r}1,800 \\
11,700 \\
102,900 \\
261,600\end{array}$ & $\begin{array}{r}1,800 \\
11,700 \\
102,900 \\
261,600\end{array}$ & $\begin{array}{l}215.5 \\
215.5 \\
215.5 \\
215.5\end{array}$ & $\begin{array}{l}215.0 \\
214.3 \\
212.5 \\
209.7\end{array}$ & $\begin{array}{r}0.32 \times 10^{-8} \\
.11 \times 10^{-8} \\
.03 \times 10^{-8} \\
.02 \times 10^{-8}\end{array}$ & $\begin{array}{l}-1.96 \times 10^{1} \\
-2.06 \times 10^{1} \\
-2.19 \times 10^{1} \\
-2.23 \times 10^{1}\end{array}$ \\
\hline $\begin{array}{l}1,800 \\
1,800 \\
1,800\end{array}$ & $\begin{array}{r}11,700 \\
102,900 \\
261,600\end{array}$ & $\begin{array}{r}9,900 \\
101,100 \\
259,800\end{array}$ & $\begin{array}{l}215.0 \\
215.0 \\
215.0\end{array}$ & $\begin{array}{l}214.3 \\
212.5 \\
209.7\end{array}$ & $\begin{array}{l}.08 \times 10^{-8} \\
.03 \times 10^{-8} \\
.02 \times 10^{-8}\end{array}$ & $\begin{array}{l}-2.09 \times 10^{1} \\
-2.19 \times 10^{1} \\
-2.23 \times 10^{1}\end{array}$ \\
\hline $\begin{array}{l}11,700 \\
11,700\end{array}$ & $\begin{array}{l}102,900 \\
261,600\end{array}$ & $\begin{array}{r}91,200 \\
249,900\end{array}$ & $\begin{array}{l}214.3 \\
214.3\end{array}$ & $\begin{array}{l}212.5 \\
209.7\end{array}$ & $\begin{array}{l}.03 \times 10^{-8} \\
.02 \times 10^{-8}\end{array}$ & $\begin{array}{l}-2.19 \times 10^{1} \\
-2.23 \times 10^{1}\end{array}$ \\
\hline 102,900 & 261,600 & 158,700 & 212.5 & 209.7 & $.02 \times 10^{-8}$ & $-2.23 \times 10^{1}$ \\
\hline \multicolumn{5}{|c|}{ Average hydraulic conductivity: } & $0.07 \times 10^{-8}$ & $-2.16 \times 10^{1}$ \\
\hline
\end{tabular}


Table 24. Falling-head permeameter results for sample 4 from core taken from core hole EC-2, Franklin Lake playa. $\left[t_{1}\right.$, starting time; $t_{2}$, ending time; $t$, elapsed time; $H_{1}$, hydraulic head at starting time; $H_{2}$, hydraulic head at ending time; $K$, hydraulic conductivity; $s$, seconds; $\mathrm{cm}$, centimeters; $\mathrm{cm} / \mathrm{s}$, centimeters per second; core length, $4.2 \mathrm{~cm}$; core diameter, $5.2 \mathrm{~cm}]$

\begin{tabular}{|c|c|c|c|c|c|c|}
\hline $\begin{array}{r}t_{1} \\
(\mathrm{~s})\end{array}$ & $\begin{array}{c}t_{2} \\
(\mathrm{~s})\end{array}$ & $\begin{array}{l}t_{1} \\
(\mathrm{~s})\end{array}$ & $\begin{array}{c}H_{1} \\
(\mathrm{~cm})\end{array}$ & $\begin{array}{c}\mathrm{H}_{2} \\
(\mathrm{~cm})\end{array}$ & $\begin{array}{c}K \\
(\mathrm{~cm} / \mathrm{s})\end{array}$ & $\ln K$ \\
\hline $\begin{array}{l}0 \\
0 \\
0 \\
0\end{array}$ & $\begin{array}{r}1,800 \\
11,700 \\
102,900 \\
261,600\end{array}$ & $\begin{array}{r}1,800 \\
11,700 \\
102,900 \\
261,600\end{array}$ & $\begin{array}{l}217.7 \\
217.7 \\
217.7 \\
217.7\end{array}$ & $\begin{array}{l}217.0 \\
214.0 \\
200.1 \\
194.7\end{array}$ & $\begin{array}{r}0.42 \times 10^{-8} \\
.35 \times 10^{-8} \\
.19 \times 10^{-8} \\
.10 \times 10^{-8}\end{array}$ & $\begin{array}{l}-1.93 \times 10^{1} \\
-1.95 \times 10^{1} \\
-2.01 \times 10^{1} \\
-2.07 \times 10^{1}\end{array}$ \\
\hline $\begin{array}{l}1,800 \\
1,800 \\
1,800\end{array}$ & $\begin{array}{r}11,700 \\
102,900 \\
261,600\end{array}$ & $\begin{array}{r}9,900 \\
101,000 \\
59,800\end{array}$ & $\begin{array}{l}217.0 \\
217.0 \\
217.0\end{array}$ & $\begin{array}{l}214.0 \\
200.1 \\
194.7\end{array}$ & $\begin{array}{l}.33 \times 10^{-8} \\
.19 \times 10^{-8} \\
.10 \times 10^{-8}\end{array}$ & $\begin{array}{l}-1.95 \times 10^{1} \\
-2.01 \times 10^{1} \\
-2.07 \times 10^{1}\end{array}$ \\
\hline $\begin{array}{l}11,700 \\
11,700\end{array}$ & $\begin{array}{l}102,900 \\
261,600\end{array}$ & $\begin{array}{r}91,200 \\
249,900\end{array}$ & $\begin{array}{l}214.0 \\
214.0\end{array}$ & $\begin{array}{l}200.1 \\
194.7\end{array}$ & $\begin{array}{l}.18 \times 10^{-8} \\
.09 \times 10^{-8}\end{array}$ & $\begin{array}{l}-2.01 \times 10^{1} \\
-2.08 \times 10^{1}\end{array}$ \\
\hline 102,900 & 261,600 & 158,700 & 200.1 & 194.7 & $.04 \times 10^{-8}$ & $-2.16 \times 10^{1}$ \\
\hline \multicolumn{5}{|c|}{ Average hydraulic conductivity: } & $0.20 \times 10^{-8}$ & $-2.03 \times 10^{1}$ \\
\hline
\end{tabular}

Table 25. Falling-head permeameter results for sample 3 from core taken from piece 7 from core hole EC-3, Franklin Lake playa.

$\left[t_{1}\right.$, starting time; $t_{2}$, ending time; $t$, elapsed time; $H_{1}$, hydraulic head at starting time; $H_{2}$, hydraulic head at ending time; $K$, hydraulic conductivity; $\mathrm{s}$, seconds; $\mathrm{cm}$, centimeters; $\mathrm{cm} / \mathrm{s}$, centimeters per second; core length, $4.2 \mathrm{~cm}$; core diameter, $5.2 \mathrm{~cm}]$

\begin{tabular}{|c|c|c|c|c|c|c|}
\hline $\begin{array}{l}t_{1} \\
(s)\end{array}$ & $\begin{array}{r}t_{2} \\
(s)\end{array}$ & $\begin{array}{c}t_{1} \\
(s)\end{array}$ & $\begin{array}{c}H_{1} \\
(\mathrm{~cm})\end{array}$ & $\begin{array}{c}\mathrm{H}_{2} \\
(\mathrm{~cm})\end{array}$ & $\begin{array}{c}K \\
(\mathrm{~cm} / \mathrm{s})\end{array}$ & $\ln K$ \\
\hline $\begin{array}{l}0 \\
0 \\
0 \\
0 \\
0\end{array}$ & $\begin{array}{r}25,840 \\
68,640 \\
97,080 \\
365,160 \\
416,820\end{array}$ & $\begin{array}{r}15,840 \\
68,640 \\
97,080 \\
365,160 \\
416,820\end{array}$ & $\begin{array}{l}120.5 \\
120.5 \\
120.5 \\
120.5 \\
120.5\end{array}$ & $\begin{array}{r}109.8 \\
90.4 \\
84.3 \\
73.6 \\
72.5\end{array}$ & $\begin{array}{r}2.75 \times 10^{-8} \\
1.96 \times 10^{-8} \\
1.72 \times 10^{-8} \\
.63 \times 10^{-8} \\
.57 \times 10^{-8}\end{array}$ & $\begin{array}{l}-1.74 \times 10^{1} \\
-1.77 \times 10^{1} \\
-1.79 \times 10^{1} \\
-1.89 \times 10^{1} \\
-1.90 \times 10^{1}\end{array}$ \\
\hline $\begin{array}{l}15,840 \\
15,840 \\
15,840 \\
15,840\end{array}$ & $\begin{array}{r}68,640 \\
97,080 \\
365,160 \\
416,820\end{array}$ & $\begin{array}{r}52,800 \\
81,240 \\
349,320 \\
400,050\end{array}$ & $\begin{array}{l}109.8 \\
109.8 \\
109.8 \\
109.8\end{array}$ & $\begin{array}{l}90.4 \\
84.3 \\
73.6 \\
72.5\end{array}$ & $\begin{array}{r}2.55 \times 10^{-8} \\
2.06 \times 10^{-8} \\
.66 \times 10^{-8} \\
.59 \times 10^{-8}\end{array}$ & $\begin{array}{l}-1.75 \times 10^{1} \\
-1.77 \times 10^{1} \\
-1.88 \times 10^{1} \\
-1.89 \times 10^{1}\end{array}$ \\
\hline $\begin{array}{l}68,640 \\
68,640 \\
68,640\end{array}$ & $\begin{array}{r}97,080 \\
365,160 \\
416,820\end{array}$ & $\begin{array}{r}28,440 \\
296,520 \\
348,180\end{array}$ & $\begin{array}{l}90.4 \\
90.4 \\
90.4\end{array}$ & $\begin{array}{l}84.3 \\
73.6 \\
72.5\end{array}$ & $\begin{array}{r}2.53 \times 10^{-8} \\
.43 \times 10^{-8} \\
.40 \times 10^{-8}\end{array}$ & $\begin{array}{l}-1.75 \times 10^{1} \\
-1.93 \times 10^{1} \\
-1.93 \times 10^{1}\end{array}$ \\
\hline $\begin{array}{l}97,080 \\
97,080\end{array}$ & $\begin{array}{l}365,160 \\
416,820\end{array}$ & $\begin{array}{l}268,080 \\
319,740\end{array}$ & $\begin{array}{l}84.3 \\
84.3\end{array}$ & $\begin{array}{l}73.6 \\
72.5\end{array}$ & $\begin{array}{l}.34 \times 10^{-8} \\
.32 \times 10^{-8}\end{array}$ & $\begin{array}{l}-1.95 \times 10^{1} \\
-1.96 \times 10^{1}\end{array}$ \\
\hline 365,160 & 416,820 & 51,660 & 73.6 & 72.5 & $.22 \times 10^{-8}$ & $-1.99 \times 10^{1}$ \\
\hline \multicolumn{5}{|c|}{ Average hydraulic conductivity: } & $1.22 \times 10^{-8}$ & $-1.86 \times 10^{1}$ \\
\hline
\end{tabular}


Table 26. Falling-head permeameter results for sample 4 from core taken from piece 7 from core hole EC-3, Franklin Lake playa.

$\left[t_{1}\right.$, starting time; $t_{2}$, ending time; $t$, elapsed time; $H_{1}$, hydraulic head at starting time; $H_{2}$, hydraulic head at ending time; $K$, hydraulic conductivity; s, seconds; $\mathrm{cm}$, centimeters; $\mathrm{cm} / \mathrm{s}$, centimeters per second; core length, $4.2 \mathrm{~cm}$; core diameter, $5.2 \mathrm{~cm}]$

\begin{tabular}{|c|c|c|c|c|c|c|}
\hline $\begin{array}{r}t_{1} \\
(s)\end{array}$ & $\begin{array}{r}t_{2} \\
(s)\end{array}$ & $\stackrel{t}{t_{1}}$ & $\begin{array}{c}H_{1} \\
(\mathrm{~cm})\end{array}$ & $\begin{array}{c}\mathrm{H}_{2} \\
(\mathrm{~cm})\end{array}$ & $\begin{array}{c}K \\
(\mathrm{~cm} / \mathrm{s})\end{array}$ & $\ln K$ \\
\hline $\begin{array}{l}0 \\
0 \\
0 \\
0\end{array}$ & $\begin{array}{r}15,840 \\
68,640 \\
97,080 \\
365,160\end{array}$ & $\begin{array}{r}25,840 \\
68,640 \\
97,080 \\
365,160\end{array}$ & $\begin{array}{l}132.9 \\
132.9 \\
132.9 \\
132.9\end{array}$ & $\begin{array}{l}128.4 \\
118.6 \\
115.3 \\
104.0\end{array}$ & $\begin{array}{r}0.92 \times 10^{-8} \\
.70 \times 10^{-8} \\
.62 \times 10^{-8} \\
.28 \times 10^{-8}\end{array}$ & $\begin{array}{l}-1.85 \times 10^{1} \\
-1.88 \times 10^{1} \\
-1.89 \times 10^{1} \\
-1.97 \times 10^{1}\end{array}$ \\
\hline $\begin{array}{l}15,840 \\
15,840 \\
15,840 \\
15,840\end{array}$ & $\begin{array}{r}68,640 \\
97,080 \\
365,160 \\
416,820\end{array}$ & $\begin{array}{r}52,800 \\
81,240 \\
349,320 \\
400,050\end{array}$ & $\begin{array}{l}128.4 \\
128.4 \\
128.4 \\
128.4\end{array}$ & $\begin{array}{l}118.6 \\
115.3 \\
104.0 \\
102.7\end{array}$ & $\begin{array}{l}.66 \times 10^{-8} \\
.58 \times 10^{-8} \\
.26 \times 10^{-8} \\
.25 \times 10^{-8}\end{array}$ & $\begin{array}{l}-1.88 \times 10^{1} \\
-1.90 \times 10^{1} \\
-1.98 \times 10^{1} \\
-1.98 \times 10^{1}\end{array}$ \\
\hline $\begin{array}{l}68,640 \\
68,640 \\
68,640\end{array}$ & $\begin{array}{r}97,080 \\
365,160 \\
416,820\end{array}$ & $\begin{array}{r}28,440 \\
296,520 \\
348,180\end{array}$ & $\begin{array}{l}118.6 \\
118.6 \\
118.6\end{array}$ & $\begin{array}{l}115.3 \\
104.0 \\
102.7\end{array}$ & $\begin{array}{l}.47 \times 10^{-8} \\
.21 \times 10^{-8} \\
.20 \times 10^{-8}\end{array}$ & $\begin{array}{l}-1.92 \times 10^{1} \\
-2.00 \times 10^{1} \\
-2.00 \times 10^{1}\end{array}$ \\
\hline $\begin{array}{l}97,080 \\
97,080\end{array}$ & $\begin{array}{l}365,160 \\
416,820\end{array}$ & $\begin{array}{l}268,080 \\
319,740\end{array}$ & $\begin{array}{l}115.3 \\
115.3\end{array}$ & $\begin{array}{l}104.0 \\
102.7\end{array}$ & $\begin{array}{l}.19 \times 10^{-8} \\
.08 \times 10^{-8}\end{array}$ & $\begin{array}{l}-2.01 \times 10^{1} \\
-2.09 \times 10^{1}\end{array}$ \\
\hline 365,160 & 416,820 & 51,660 & 104.0 & 102.7 & $.01 \times 10^{-8}$ & $-2.30 \times 10^{1}$ \\
\hline \multicolumn{5}{|c|}{ Average hydraulic conductivity: } & $0.39 \times 10^{-8}$ & $-1.97 \times 10^{1}$ \\
\hline
\end{tabular}

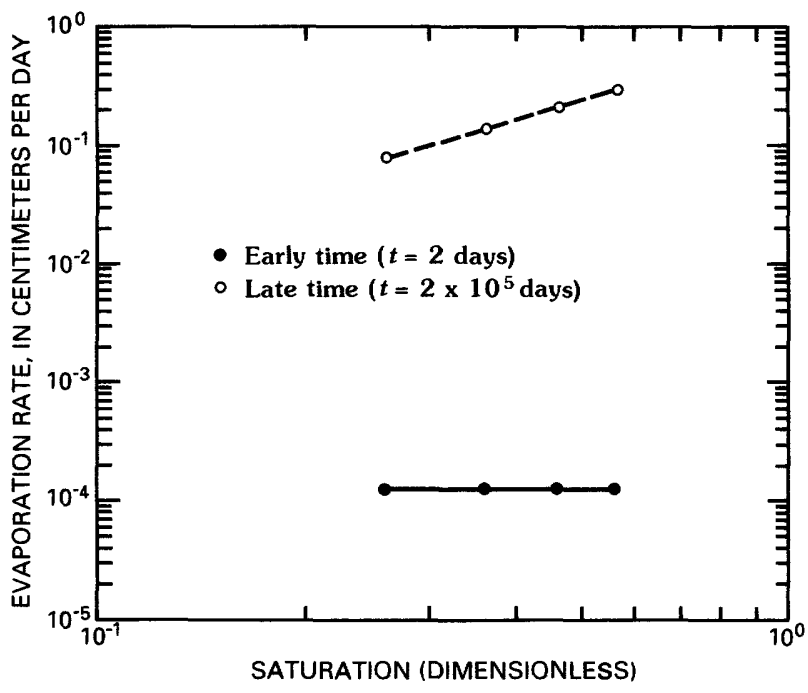

Figure 43. Sensitivity analysis of the effect of varying model value of the initial saturation.

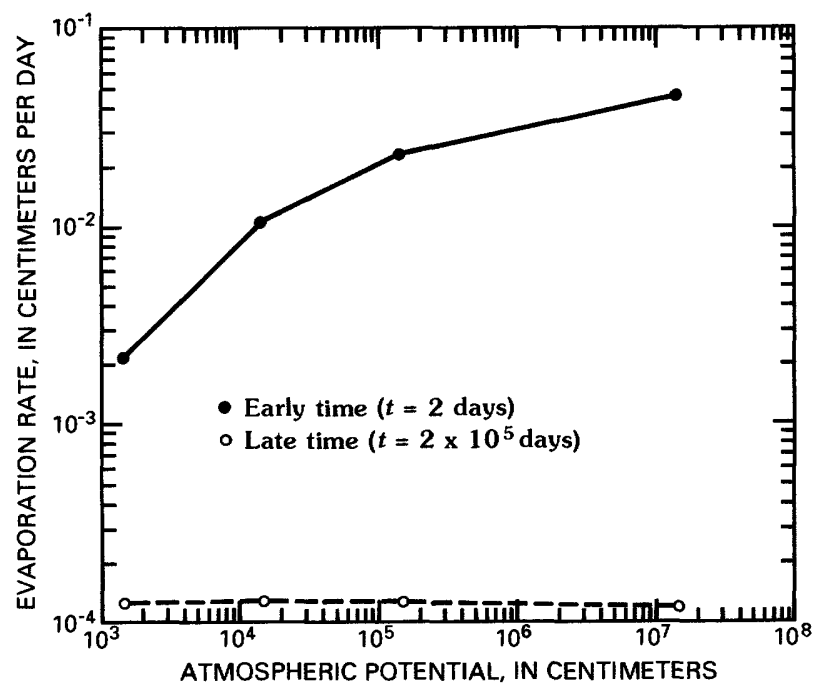

Figure 44. Sensitivity analysis of the effect of varying model value of the atmospheric potential for evaporation. 


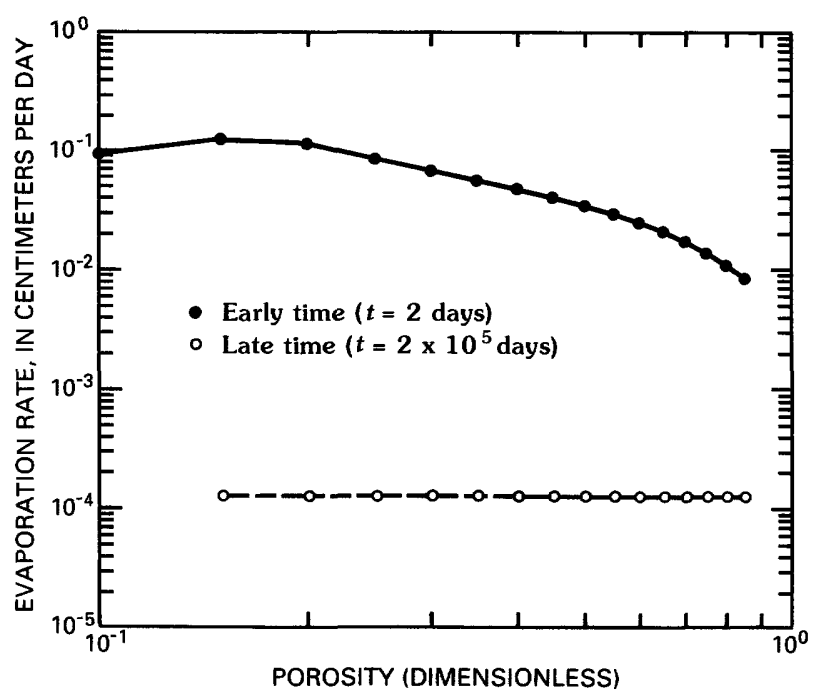

Figure 45. Sensitivity analysis of the effect of varying model value of the porosity.

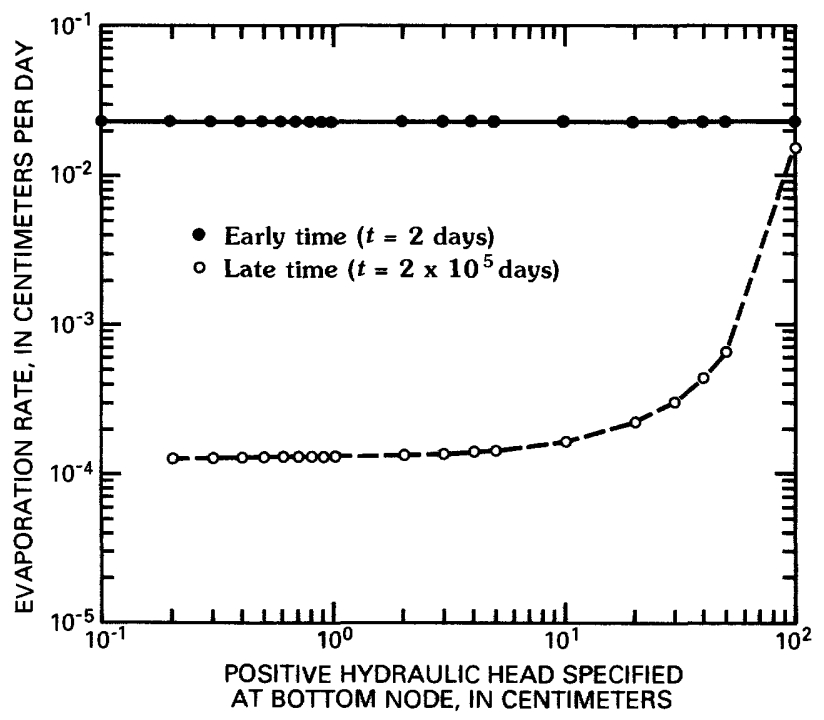

Figure 47. Sensitivity analysis of the effect of varying model value of the specified upward-head pressure at the lower boundary.

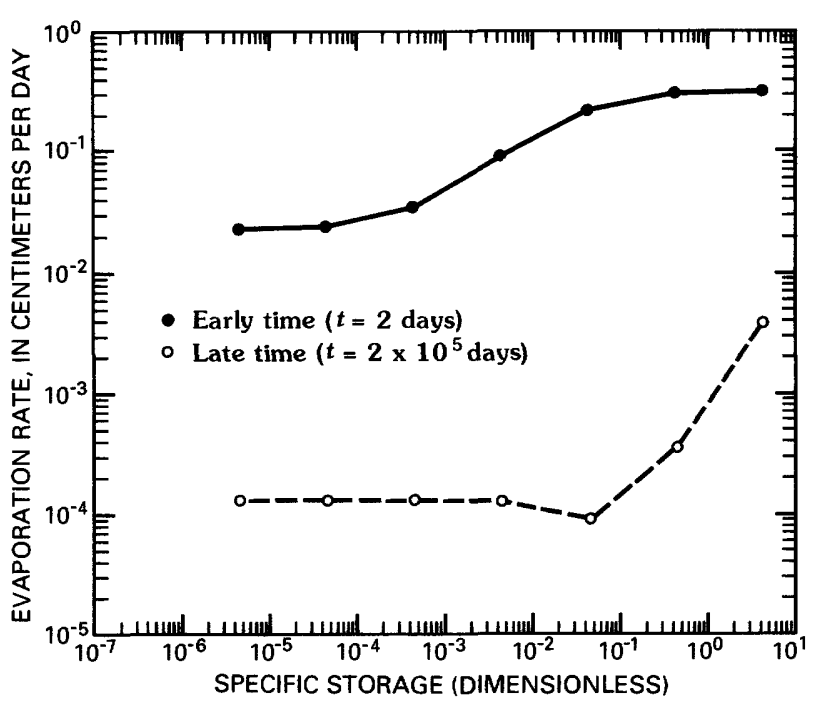

Figure 46. Sensitivity analysis of the effect of varying model value of the specific storage.

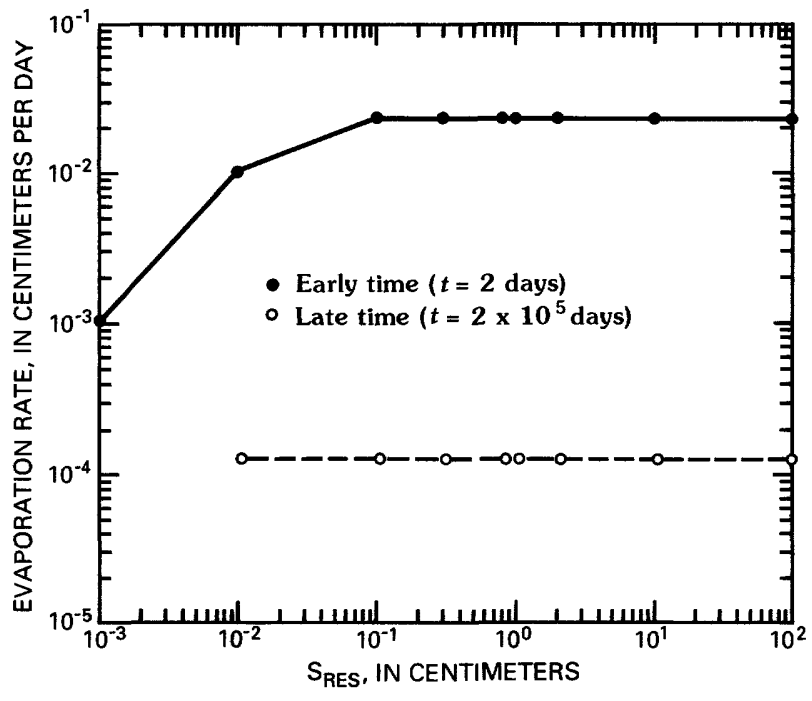

Figure 48. Sensitivity analysis of the effect of varying model value of the surface resistance to evaporative flux. 


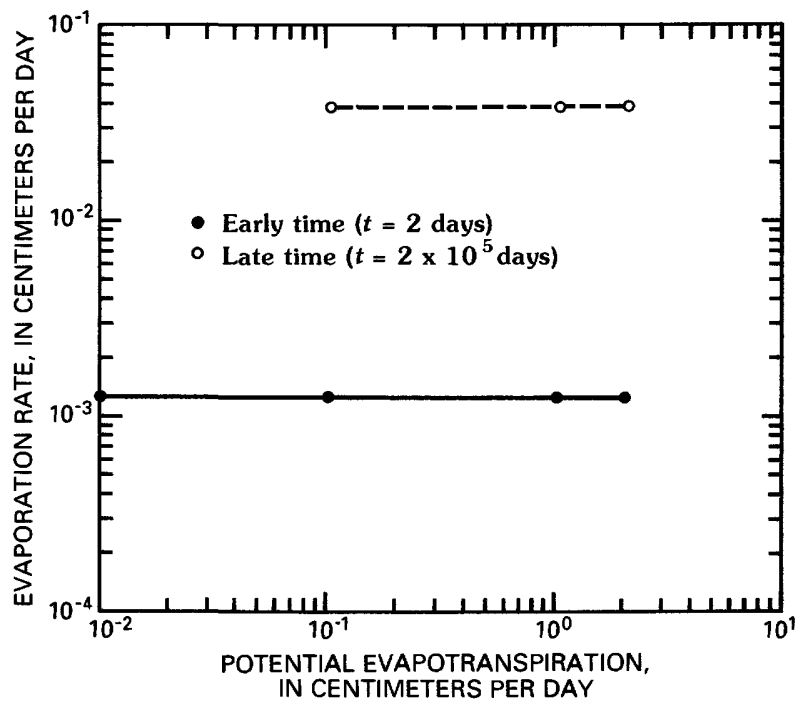

Figure 49. Sensitivity analysis of the effect of varying model value of the potential evapotranspiration. 


\section{APPENDIX}




\section{APPENDIX}

Units of constants used in equations to estimate potential evapotraspiration (PET)

\begin{tabular}{ccl}
\hline Equation & Constant & \multicolumn{1}{c}{ Units } \\
\hline 10 & 0.0018 & millimeter month $\left./{ }^{\circ} \mathrm{C}\right)^{2}$ \\
11 & 0.5625 & centimeters/month/millibar \\
13 & 0.013 & millimeters/langley \\
14 & $\mathrm{C}_{\mathrm{T}}$ & centimeters $/\left({ }^{\circ} \mathrm{C} \cdot\right.$ langley $)$ \\
& & \\
16 & 0.014 & ${ }^{\circ} \mathrm{F}^{-1}$ \\
16 & 0.37 & dimensionless \\
16 & 1500 & langleys $/$ inch \\
17 & 1.9 & centimeters $/{ }^{\circ} \mathrm{C} \cdot$ day \\
18 & 0.167 & millimeters $/$ langley \\
& & \\
18 & 0.014 & millimeter $/$ kilometer $\cdot{ }^{\circ} \mathrm{C}$ \\
18 & 22.0 & dimensionless \\
18 & 0.15 & ${ }^{\circ} \mathrm{C}-1$ \\
$19 A$ & 0.0066 & centimeters $/$ day $\cdot{ }^{\circ} \mathrm{C}$ \\
& & \\
& 0.055 & centimeters $/$ day \\
$19 B$ & 0.00036 & centimeters/langley \\
& 0.038 & centimeters/day \\
$19 \mathrm{C}$ & 0.0021 & centimeters/day $\cdot{ }^{\circ} \mathrm{C}$ \\
& 0.0003 & centimeters/langley \\
& 0.025 & centimeters/day \\
\hline
\end{tabular}

